Argonne Mational Laboratom

REACTOR DEVELOPMENT PROGRAM

PROGRESS REPORT

December 1966

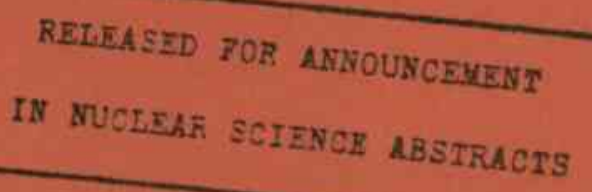




\section{DISCLAIMER}

This report was prepared as an account of work sponsored by an agency of the United States Government. Neither the United States Government nor any agency Thereof, nor any of their employees, makes any warranty, express or implied, or assumes any legal liability or responsibility for the accuracy, completeness, or usefulness of any information, apparatus, product, or process disclosed, or represents that its use would not infringe privately owned rights. Reference herein to any specific commercial product, process, or service by trade name, trademark, manufacturer, or otherwise does not necessarily constitute or imply its endorsement, recommendation, or favoring by the United States Government or any agency thereof. The views and opinions of authors expressed herein do not necessarily state or reflect those of the United States Government or any agency thereof. 


\section{DISCLAIMER}

Portions of this document may be illegible in electronic image products. Images are produced from the best available original document. 
The facilities of Argonne National Laboratory are owned by the United States Government. Under the terms of a contract (W-31-109-Eng-38) between the U. S. Atomic Energy Commission, Argonne Universities Association and The University of Chicago, the University employs the staff and operates the Laboratory in accordance with policies and programs formulated, approved and reviewed by the Association.

\section{MEMBERS OF ARGONNE UNIVERSITIES ASSOCIATION}

The University of Arizona. Carnegie Institute of Technology Case Institute of Technology The University of Chicago University of Cincinnati Illinois Institute of Technology University of Illinois Indiana University Iowa State University
The University of Iowa Kansas State University The University of Kansas Loyola University Marquette University Michigan State University The University of Michigan University of Minnesota University of Missouri
Northwestern University University of Notre Dame The Ohio State University Purdue University Saint Louis University Washington University Wayne State University The University of Wisconsin

\section{LEGAL NOTICE}

This report was prepared as an account of Government sponsored work. Neither the United States, nor the Commission, nor any person acting on behalf of the Commission:

A. Makes any warranty or representation, expressed or implied, with respect to the accuracy, completeness, or usefulness of the information contained in this report, or that the use of any information, apparatus, method, or process disclosed in this report may not infringe privately owned rights; or

B. Assumes any liabilities with respect to the use of, or for damages resulting from the use of any information, apparatus, method, or process disclosed in this report.

As used in the above, "person acting on behalf of the Commission" includes any employee or contractor of the Commission, or employee of such contractor, to the extent that such employee or contractor of the Commission, or employee of such contractor prepares, disseminates, or provides access to, any information pursuant to his employment or contract with the Commission, or his employment with such contractor.

Printed in the United States of America

Available from

Clearinghouse for Federal Scientific and Technical Information

National Bureau of Standards, U.S. Department of Commerce

Springfield, Virginia 22151

Price: Printed Copy $\$ 3.00 ;$ Microfiche $\$ 0.65$ 
ANL-7286

Reactor Technology

(TID-4500)

AEC Research and

Development Report

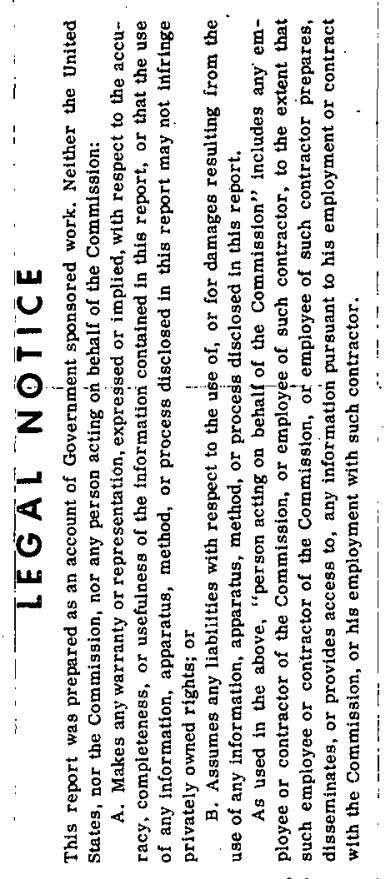

\author{
ARGONNE NATIONAL LABORATORY \\ 9700 South Cass Avenue \\ Argonne, Illinois: 60439
}

\title{
OAII PRTCES
}

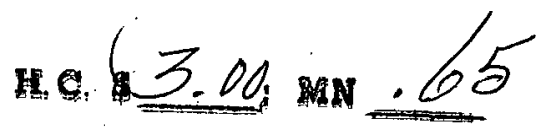

\section{REACTOR DEVELOPMENT PROGRAM} PROGRESS REPORT.

December 1966

Albert V. Crewe, Laboratory Director

Stephen Lawroski, Associate Laboratory Director

Division

Chemical Engineering

Idaho

Metallurgy

Reactor Engineering

Reactor Physics

Remote Control

\section{Director}

R. C. Vogel

M. Novick

M. V. Nevitt

L. J. Koch

R. Avery

D. P. Mingesz (Acting)

Report coordinated by

R. M. Adams and A. Glassner

Issued January,26, 1967 
The Reactor Development Program Progress Report, is sued monthly, is intended to be a means of reporting those items of significant technical progress which have occurred in both the specific reactor projects and the general engineering research and development programs. The report is or ganized in a way which, it is hoped, gives the clearest, most logical overall view of progress. The budget classification is followed only in broad outline, and no attempt is made to report separately on each sub-activity number. Further, since the intent is to report only items of significant progress, not all activities are reported each month. In order to issue this report as soon as possible after the end of the month editorial work must necessarily be limited. Also, since this is an informal progress report, the results and data presented should be understood to be preliminary and subject to change unless otherwise stated.

The issuance of these reports is not intended to constitute publication in any sense of the word. Final results either will be submitted for publication in regular professional journals or will be published in the form of ANL topical reports.

The last six reports issued in this series are:

June 1966

July 1966

August 1966

September 1966

October 1966

November 1966
ANL-7230

ANL-7245

ANL-7249

ANL-7.255

ANL-7267

ANL-7279 
REACTOR DEVELOPMENT PROGRAM

Highlights of Project Activities for December 1966

.

EBWR Plutonium Recycle Program

EBWR is operating at $40 \mathrm{MW}$. At the present level of operation, the average exposure in the plutonium zone will reach approximately $900 \mathrm{MWd} /$ tonne by the end of the present fiscal year.

EBR - II

Operation of the reactor has been very satisfactory with Run No. 23 (690 MWd) completed on December 3 and Run No. 24 (630 MWd) completed on December 31, for a total integrated reactor time of $12,245 \mathrm{MWd}$. The rotating plug seal troughs continued to operate very smoothly; only $3 \frac{3}{4} \mathrm{hr}$ were required between Runs No. 23 and 24 to bring the seal alloy to the molten condition. The rotating oscillator was operated this month for the first time to obtain reactor kinetics data. For Run No. 25, scheduled for January, it is planned to increase the core size of the reactor from 81 to 91 subassemblies and, likewise, to increase the number of experimental capsules in the reactor from 235 to 292.

Thirteen fuel subassemblies were fabricated this month, which is in excess of the normal capabilities of the Fuel Cycle Facility.

Plans are being formulated and implemented to expand the output of FCF by augmenting the operating and analytical staff, procuring additional equipment, and by minor modifications to the facility, with the ultimate objective of attaining a higher reactor plant factor. Some of the details of this imminent program are discussed in the current report.

ZPPR

Construction of the facility is on schedule. All foundation posts for the reactor cell are in place, and pouring of concrete has been completed on the service wing foundation and the floor slab, as well as the east and interior walls of the vault workroom area. Seventy-five percent of the north and south walls of this building have been completed. Excavation for the AFSR foundation has begun.

$\underline{\mathrm{ZPR}-3}$

Results of heterogeneity experiments with Assembly 48, a large, dilute, plutonium-fueled core, are given. A series of experiments with 
Assembly $48 \mathrm{~A}$ was initiated this month for PNL, and is scheduled for 8 weeks in support of the FFTF design group. The experiments consist largely of measurements of control-rod worths, centrally and in the reflector.

AARR

Burns and Roe have completed the final draft of specifications for Construction Package No. 1, the primary pumps, and the primary heat exchanger.

The materials compatibility and corrosion studies being performed by ORNL have been completed and a final report issued. All work in this area has been terminated. 
I. PLUTONIUM UTILIZATION

A. Research and Development 1

1. EBWR Plutonium Recycle Program . . . 1

II. LIQUID-METAL FAST BREEDER REACTOR . 2

A. EBR-II 2

1. Operations 2

2. Transfer-function Measurements 5

3. Reactor Physics 7

4. Plant Modification 7

5. Surveillance 8

6. Fuel Cycle Facility (FCF) 9

B. Physics Development $\quad 12$

1. ZPR-3 12

2. $\mathrm{ZPR}-6$. 16

3. ZPR-9 16

4. ZPPR 18

C. Component Development 21

1. Sodium Technology and Development 21

2. Materials Evaluation 21

D. Fuel Development $\quad 22$

1. Ir radiation of Uranium-Plutonium Alloys 22

2. Oxide and Carbide Fuels 24

3. Fuel Cladding and Structure. 30

4. Fuel Reprocessing : . . 32

E. Design Concept Analyses and Advanced Systems Evaluation

1. 1000-MWe Study 34

F. General Research and Development 34

1. Fast Reactor Core Parameter Study 34 
III. GENERAL REACTOR TECHNOLOGY $\quad 36$

A. Applied and Reactor Physics Development. . . 36

1. $\mathrm{Li}^{6}$ Fast Neutron Spectrometer. 36

2. Variational Methods for Two-dimensional $\begin{array}{ll}\text { Kinetics Calculations : } & 37\end{array}$

3. Effects of Cross-section Errors on Neutron $\begin{array}{ll}\text { Spectra } & 38\end{array}$

4. The ARC System 40

B. Fuels and Cladding $\quad 45$

1. Irradiation of High-temperature Materials 45

2. Radiation Damage to Structural Materials 45

3. Techniques of Fabrication and Testing 47

C. Engineering Development $\quad 48$

1. Electric Master-Slave Manipulator, Mark E4A 48

2. Studies of Structural Dynamics of Core. 48

3. Heat Transfer, Fluid Flow, and Mechanics of Materials

D. Chemistry and Chemical Separations 51

1. Fluoride Volatility Processes 51

IV. ADVANCED SYSTEMS RESEARCH AND DEVELOPMENT 56

A. Argonne Advanced Research Reactor (AARR) 56

1. General 56

2. Studies of Materials Compatibility and Corrosions 56

3. Steady-state Heat-transfer Program 58

4. Physics Experiments and Analysis 64.

V. NUCLEAR SAFETY 66

A. Coolant Dynamics 66

1. Coolant (Water) Expulsion Studies 66

2. Superheat Experiments $\quad \therefore \quad 66$ 
TABLE OF CONTENTS

$\underline{\text { Page }}$

3. Studies of Critical Flow

66

4. Effect of Rapid Heating of Reactor Components

B. Fuel Meltdown Studies with TREAT

1. Data from Transient 1048

2. Examination of Loop Test Section after

Transient 1048

3. Development of Mark-II Integral Sodium Loop Pump

C. Accident Analyses

1. Safety Analysis Computing System

74

2. Quasistatic Excursion Code QXI

D. TREAT

1. Operations

E. Chemical and Associated Energy Problems (Thermal)

1. Metal-Water Reactions

F. Engineering Safeguards Systems

1. Containment 


\section{PLUTONIUM UTILIZATION}

A. Rèsearch and Development

1. EBWR Plutonium Recycle Program

EBWR is operating at $40 \mathrm{MW}$. At the present level of operation, the average exposure in the plutonium zone will reach approximately $900 \mathrm{MWd} /$ tonne by the end of the present fiscal year.

A proposal to increase the power level to $70 \mathrm{MW}$ has been submitted to the Chicago Operations Office and is being reviewed. 


\section{LIQUID-METAL FAST BREEDER REACTORS}

A. $\underline{E B R-I I}$

1. Operations

Run No. 23 completed its scheduled 690 MWd of operation on Dec 3. After necessary fuel handling and scheduled minor maintenance, Run No. 24, planned for $630 \mathrm{MWd}$ of operation, was begun on Dec 9. Because of excessive friction in the rotary oscillator, requiring temporary discontinuation of its use, as described below, this run was interrupted on Dec 24 to await approval to install a stainless steel control rod for the purpose of monitoring reactor kinetics by rod-drop techniques. The run was resumed Dec 29 following the receipt of such approval, and completed on Dec 31 for a total integrated reactor time of $12,245 \mathrm{MWd}$. This delay is not expected to affect the startup of Run No. 25.

Use of the new rotary oscillator in the reactor during power operation was begun at midmonth. A series of kinetics measurements were made at $30 \mathrm{MW}, 100 \%$ flow, at frequencies from 0.007 to $8 \mathrm{cps}$. Operation appeared to be satisfactory. Oscillations were next made at $30 \mathrm{MW}$ and $100 \%$ flow, $500 \mathrm{~kW}$ and $100 \%$ flow, and $20 \mathrm{MW}$ and $52 \%$ flow. As the outlet temperature of the reactor coolant increased, it was noted that some binding occurred in the oscillator system at rotational frequencies below $0.3 \mathrm{cps}$. Further testing indicated a definite binding, apparently between the oscillator rod and thimble, occurring at average coolant temperature rise of greater than $90^{\circ} \mathrm{F}$ and for rotational speeds less than $0.3 \mathrm{cps}$. Finally, at $45 \mathrm{MW}$ and $100 \%$ flow, measurements indicated that the friction was excessive, and the decision was made not to operate the oscillator under these conditions. At this point approval was requested and later received to insert the stainless steel control rod in place of a normal one to obtain kinetics data by the rod-drop technique. These data are important as a reference base in view of the proposed core change from 81 to 91 subassemblies for the next power run.

Upon resumption of Run No. 24, rod-drop data were obtained at $500 \mathrm{~kW}, 30 \mathrm{MW}$, and $45 \mathrm{MW}$.

Plans are being made for the removal and inspection of the oscillator rod and thimble when replacements àre available.

Nine outer blanket subassemblies were raised slightly and reseated to test for any indication of adhesion or binding. This is a continuation of the surveillance previously carried out in Dec 1965 and June 1966. At least one subassembly in each row and sector are raised during the testing period. No adverse results were observed. 
Core changes for Run No. 24 involved the exchange of 19 subas semblies. Experimental subassembly XA07 was removed at the request of the experimenter, and XO18 containing structural and materials samples was inserted. Two outer-blanket alpha-measurement subassemblies were removed after long residence in Rows 13 and 15, respectively.

Several maintenance tasks, originally scheduled following Run No. 24, were performed during the reactor down time during the interruption of the run. These included the following: (1) the main turbine emergency governor (overspeed) was removed and sent to the manufacturer for inspection and testing; (2) the turbine-driven condensate pump was disassembled for annual inspection; (3) inspection and modifications were begun on the fuelunloading-machine gripper-sense-indication system.

During the required balance of Run No. 24 the turbine-generator was not operated and steam was bypassed directly to the condenser.

a. Rotating Plugs. On Dec 3, preparatory to the fuel-handling operations following Run No. 23, the large plug was rotated without difficulty after being in the molten mode of operation for about $3 \frac{3}{4} \mathrm{hr}$. The small plug was rotated after about $4 \mathrm{hr}$. Subsequent performance during fuel handling was normal in all respects. The seals were returned to the halfmolten mode of operation on Dec 7, preparatory to Run No. 24.

To check alloy composition, samples for analysis were taken from the seal troughs on Dec 6. The results are shown in Table I. The original average composition of the alloy when first placed in the seal was about $58 \mathrm{w} / \mathrm{O} \mathrm{Bi}$ and $42 \mathrm{w} / \mathrm{o} \mathrm{Sn}$, with a melting point of $281^{\circ} \mathrm{F}$. The indicated present deviation from this analysis is not considered significant.

TABLE I. Chemical Analyses of Seal-trough Materials

\begin{tabular}{llcc}
\hline \multicolumn{1}{c}{ Sample Description } & \multicolumn{2}{c}{ Constituent } \\
\cline { 2 - 4 } & $\begin{array}{c}\mathrm{Bi} \\
(\mathrm{w} / \mathrm{o})\end{array}$ & $\begin{array}{c}\mathrm{Na} \\
(\mathrm{ppm})\end{array}$ & $\begin{array}{c}\mathrm{Fe} \\
\text { (ppm) }\end{array}$ \\
\hline $\begin{array}{l}\text { Alloy from outer annulus of large } \\
\text { plug trough, taken near alloy sur- } \\
\text { face (7 in. above bottom of trough) }\end{array}$ & 59.2 & 2400 & 22 \\
$\begin{array}{l}\text { Alloy from outer annulus of large } \\
\text { plug trough, taken } 2 \text { in. above bottom. }\end{array}$ & 59.0 & 2500 & 25 \\
$\begin{array}{l}\text { Alloy from outer annulus of small } \\
\text { plug. trough, taken near alloy surface } \\
\text { (7 in. above bottom of trough). }\end{array}$ & & & \\
$\begin{array}{l}\text { Alloy from outer annulus of small } \\
\text { plug trough, taken } 2 \text { in. above bottom }\end{array}$ & 58.1 & 860 & 20 \\
\hline
\end{tabular}


b. Experimental Irradiations. The status of all experimental irradiations in the reactor and the approximate exposure following completion of Run No. 24 is as follows:

\begin{tabular}{|c|c|c|c|c|c|}
\hline Subàs sembly & $\begin{array}{l}\text { Date } \\
\text { Loaded }\end{array}$ & $\begin{array}{l}\text { Capsule Content and } \\
\text { Number of Capsules ( ) }\end{array}$ & $\begin{array}{l}\text { Experi- } \\
\text { menter }\end{array}$ & $\begin{array}{l}\text { Approximate } \\
\text { Accumulated } \\
\text { Exposure } \\
\text { (MWd) }\end{array}$ & $\begin{array}{l}\text { Goal } \\
\text { Exposure } \\
(\mathrm{MWd})\end{array}$ \\
\hline $\mathrm{XG02}$ & $7 / 16 / 65$ & $\begin{array}{l}\mathrm{UO}_{2}-20 \mathrm{w} / \mathrm{o} \mathrm{PuO}_{2}(1) \\
\text { Stainless Dummies (18) }\end{array}$ & $G E$ & 9,744 & 13,600 \\
\hline XGं03 & $7 / 16 / 65$ & $\begin{array}{l}\mathrm{UO}_{2}-20 \mathrm{w} / \mathrm{O} \mathrm{PuO}_{2}(2) \\
\text { Stainless Dummies (17) }\end{array}$ & $\mathrm{GE}$ & 9,744 & 19,450 \\
\hline $\mathrm{XG04}$ & $7 / 16 / 65$ & $\begin{array}{l}\mathrm{UO}_{2}-20 \mathrm{w} / \mathrm{o} \mathrm{PuO}_{2}(2) \\
\text { Stainless Dummies (17) }\end{array}$ & $G E$ & 9,744 & 39.000 \\
\hline XG05 & $9 / 3 / 65$ & $\begin{array}{l}\mathrm{UO}_{2}-20 \mathrm{w} / 0 \mathrm{PuO}_{2}(9) \\
\mathrm{U}-15 \mathrm{w} / \mathrm{OPu}-10 \mathrm{w} / \mathrm{O} \mathrm{Zr}(1) \\
\mathrm{U}-15 \mathrm{w} / \mathrm{o} \mathrm{Pu}-10 \mathrm{w} / \mathrm{O} \mathrm{Ti}(1) \\
\mathrm{UC}-20 \mathrm{w} / \mathrm{OuC}(3) \\
\text { Structural (5) }\end{array}$ & $\begin{array}{l}\text { GE } \\
\text { ANL } \\
\text { ANL } \\
\text { ANL } \\
\text { GE }\end{array}$ & 9,317 & 10,300 \\
\hline XG06 & $9 / 3 / 65$ & $\begin{array}{l}\mathrm{UO}_{2}-20 \mathrm{w} / \mathrm{o} \mathrm{PuO}_{2}(12) \\
\mathrm{U}-15 \mathrm{w} / \mathrm{O} \mathrm{Pu}-10 \mathrm{w} / 0 \mathrm{Zr} \text { (1) } \\
\mathrm{U}-15 \mathrm{w} / \mathrm{O} \mathrm{Pu}-10 \mathrm{w} / 0 \mathrm{Ti} \text { (1) } \\
\text { Structural (5) }\end{array}$ & $\begin{array}{l}\text { GE } \\
\text { ANL } \\
\text { ANL }\end{array}$ & 9,317 & 20,600 \\
\hline $\mathrm{XA08}$ & $12 / 13 / 65$ & $\begin{array}{l}\mathrm{UC}-20 \mathrm{w} / \mathrm{o} \mathrm{PuC}(8) \\
\text { Structural (11) }\end{array}$ & ANL & 7,495 & 19,800 \\
\hline xO10 & $3 / 24 / 66$ & $\begin{array}{l}\mathrm{UO}_{2}-20 \mathrm{w} / 0 \mathrm{PuO}_{2}(4) \\
\text { Structural (11) } \\
\text { Structural (4) }\end{array}$ & $\begin{array}{l}\text { GE } \\
\text { ANL } \\
\text { PNW L }\end{array}$ & 6,675 & 19,600 \\
\hline XOl1 & $5 / 9 / 66$ & $\begin{array}{l}\mathrm{UO}_{2}-20 \mathrm{w} / \mathrm{PuO}_{2}(7) \\
\mathrm{UO}_{2}-20 \mathrm{w} / \mathrm{\textrm {PuO } _ { 2 }}(9) \\
304 \mathrm{SS}-30 \mathrm{v} / \mathrm{o} \mathrm{PuO}_{2}(1) \\
304 \mathrm{SS}-20 \mathrm{v} / \mathrm{o} \mathrm{PuO}_{2}(1) \\
304 \mathrm{SS}-20 \mathrm{v} / \mathrm{OOO}_{2}(1)\end{array}$ & $\begin{array}{l}\text { ANL } \\
\text { GE } \\
\text { PNW L } \\
\text { PNW L } \\
\text { PNWL }\end{array}$ & 5,094 & 8,300 \\
\hline $\mathrm{xO} 12$ & $8 / 10 / 66$ & $\mathrm{UO}_{2}-20 \mathrm{w} / \mathrm{o} \mathrm{PuO}_{2}$ (19) & NuMEC & 2,975 & 20,600 \\
\hline $\mathrm{XO} 14$ & $7 / 17 / 66$ & $\begin{array}{l}\text { Structural (5) } \\
\text { Graphite (2) } \\
\text { Structural (7) } \\
\text { Structural (5) }\end{array}$ & $\begin{array}{l}\text { PNW L } \\
\text { PNW L } \\
\text { GE } \\
\text { NRL }\end{array}$ & 3,674 & (a). \\
\hline XO15 & $11 / 15 / 66$ & $\begin{array}{l}\mathrm{PuO}_{2}-\mathrm{UO}_{2}(11) \\
\mathrm{PuO}_{2}-\mathrm{UO}_{2}(2) \\
(\mathrm{Pu}, \mathrm{U}) \mathrm{C} \mathrm{(4)} \\
\mathrm{MK}-\mathrm{IA}(\text { Metal) (2) }\end{array}$ & $\begin{array}{l}\text { NuMEC } \\
\text { GE } \\
\text { ANL } \\
\text { ANL }\end{array}$ & 1,320 & 11,000 \\
\hline XO17 & $11 / 15 / 66$ & $\begin{array}{l}\mathrm{PuO}_{2}-\mathrm{UO}_{2}(11) \\
(\mathrm{Pu}, \mathrm{U}) \mathrm{C}(3) \\
\mathrm{MK}-1 \mathrm{~A}(\mathrm{Metal})\end{array}$ & $\begin{array}{l}\text { NuMEC } \\
\text { UNC } \\
\text { ANL }\end{array}$ & 1,320 & 6,500 \\
\hline XO18 & $12 / 6 / 66$ & $\begin{array}{l}\text { Structural (3) } \\
\text { Structural (1) } \\
\text { Structural (2) } \\
\text { Structural and Heavy } \\
\text { Metal Fission Yield } \\
\text { Samples (1) }\end{array}$ & $\begin{array}{l}\text { GE } \\
\text { PNW L } \\
\text { ANL }\end{array}$ & 630 & 21,300 \\
\hline
\end{tabular}

(a) Maximum attainable before removal is required for experiment of higher priority. 
The following changes to the loading of experimental subassemblies were made during the shutdown following Run No. 23.

(i) Subassembly XÄ07 was removed at the experimenter's request. The subassembly contents and exposures are:

$$
\begin{array}{ll}
16 \text { capsules, U-15 w/o Pu-11 w/o Zr } & \sim 4 \text { a/o burnup } \\
3 \text { capsules, structural } & \sim 3 \times 10^{22} \text { nvt } \\
& \text { (integrated total flux) }
\end{array}
$$

(ii) Subassemblies U-1550X and U-1511X containing special alpha-measurement foils were removed after being exposed for 9,985 MWd of reactor operation in positions $13 \mathrm{~B} 7$ and $15 \mathrm{~B} 8$, respectively.

(iii) Subas sembly XO 18 containing structural samples and about $1.4 \mathrm{~g}$ of heavy metal oxides, as shown in the status table above, was loaded into grid position $2 \mathrm{~B} 1$."

Ten structural samples of the Mk-B-19 design were received from $G E$ and are scheduled to be combined with nine similar types from ANL to form the complement for the Row -4 subassembly XOl6.

Disassembly of experimental subassemblies XA07 and XO09 was completed in the Air Cell of the Fuel Cycle Facility. Fourteen of the 16 metal fuel capsules from XA07 and five ceramic capsules from XO09 were transferred to the Laboratory's Metallurgy Division.

\section{Transfer'-function Measurements}

An on-line data-reduction system was used to produce the transferfunction data shown in Fig. 1. In the method basic Fourier analysis of data received from the oscillator mechanism and the ion-chamber signal is made. The oscillator drive produces the sine and cosine information and this, along with the ion-chamber current, is sent directly to an analog-to-digital converter in conjunction with an IBM:1620 computer. The computer then uses the digitalized data to perform the numerical integration at a rate of 60 samples per second. Processing of the data produces the Fourier components after a predetermined number of integral cycles of the oscillator.

The results tabulated by the computer are:

a. frequency of oscillation;

b. number of sample points used for the calculation;

c. real component of the Fourier coefficient;

d. imaginary component of the Fourier coefficient;

e. the absolute value of the Fourier coefficient;

f. phase angle. 


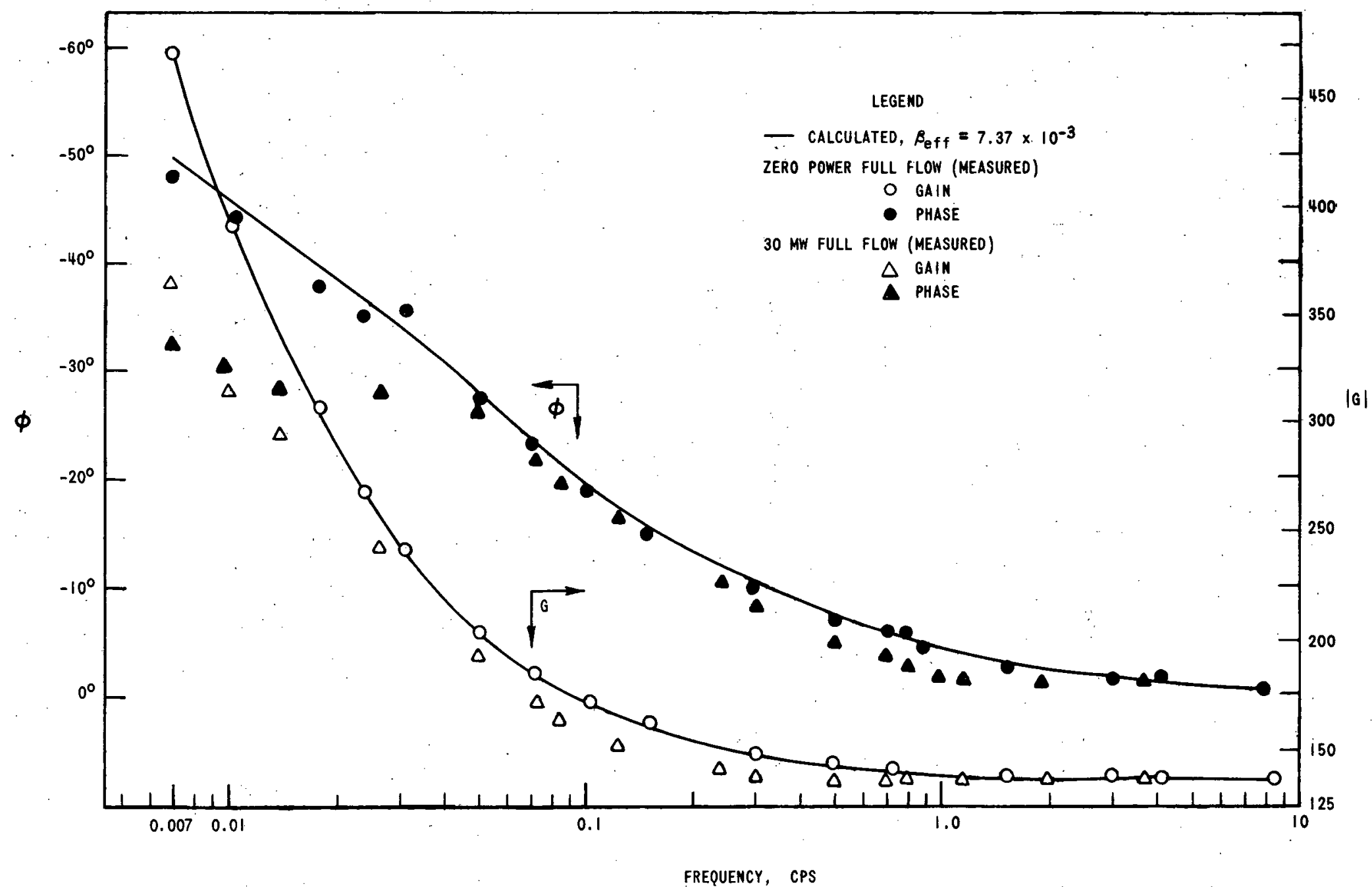

Fig. 1. EBR-II Transfer Function 
The calculated phase angle represents not only the phase characteristic of the reactor but also the phase displacement of the sine, cosine function generator with respect to the actual position of the reactivity generator. This correction, except for phase-error uncertainty due to backlash in the drive, is determined by reverse oscillation or by normalization at the highest frequency.

The zero-power results are in excellent agreement with the calculated zero-power transfer function with respect to both gain and phase. The calculated curve is based on the $\beta$ fraction used for the original transfer function $\left(\beta_{\text {eff }}=0.00736\right)$.

The transfer function data for 30-MW operation are being analyzed.

\section{Reactor Physics}

To predict the effects of changes in reactor loading on the distribution of fission rate in the reactor, it is necessary to provide computing techniques sophisticated enough to give an accurate, but simple enough, picture for routine use. To this end, considerable effort has been expended in characterizing the reactor using one- and two-dimension diffusion theory and one-dimension transport theory. The results of these calculations can be compared at present with only two sets of experimental data: (a) the flux measurements for the "wet critical" core and the fuel-burnup data obtained during the Mark-I-fuel surveillance program when the core size was about 70 subassemblies; and (b) experimental data obtained with flux wires in Run No. 20 (80-subassembly core). Some data are available from burnup detèrminations for Mark-IA fuel, but because of the changing core size and changing enrichment, these data are difficult to evaluate except on an average basis.

The results of calculation and experiment have appeared in previous monthly reports. The conclusion that must be drawn on the basis of currently available information is that the present codes are not sufficiently definitive in the regions of perturbations caused by experiments in the reactor and at or near the boundary of the core and reflector. Thus, it will be necessary to measure fission rates experimentally. throughout the core using special flux-wire subassemblies. The first measurements are planned for Run No. 25, when the core will comprise 91 subassemblies, with experiments in Rows 2, 4, and 6. The data will be used for calculating a new fission-rate distribution to be compared with results of a two-dimension transport code being prepared for EBR-II.

\section{Plant Modifications}

One of the current reactor improvements being accomplished includes the installation of a new cold trap and complete revision of the in-cell piping in the purification system for the primary sodium. The 
reason for this modification is that the current performance of the existing cold trap indicates it is nearing the end of its useful life and must soon be replaced. Most of the present piping must be removed to facilitate removal of the cold trap from the cell through the upper access opening provided for this purpose. Along with the new cold trap, a new piping system has been designed which will allow semiremote removal of the cold trap from above in the future, without disrupting the piping system. Special couplings, which may be disconnected from above with long-handled tools connect all pipe lines to the cold trap. Simple devices to detect sodium.leaks are provided beneath all couplings.

Two identical cold traps, one a spare, are ready for shipment from the manufacturer. An ANL engineer visited the manufacturer's plant this month to witness a pneumatic pressure and leak test on the sodium shells and economizer units for both cold traps.

5. Surveillance

a. Examination of Irradiated EBR-II Fuel Jacketing. In September, two Type $304 \mathrm{~L}$ stainless steel fuel jackets irradiated at 371 (at bottom) to $517^{\circ} \mathrm{C}$ (at top) in EBR-II to a fluence of $5 \times 10^{21}$ to $1.2 \times 10^{22} \mathrm{nvt}$, fast neutrons, were each cut into five nearly equal sections for tube-burst testing. The sections from one jacket were annealed at $900^{\circ} \mathrm{C}$ for one hour, to recover some of the ductility lost through atomic displacements, and were air-cooled before being tested.

Tube-burst tests at $500^{\circ} \mathrm{C}$ then showed the trend for the strengths of the unannealed jacket to be progressively greater from top to bottom, and that irradiation of the annealed jacket had changed the average tangential rupture strength and elongation from 48,000 psi and $9.7 \%$ to about 79,000 psi and about $0.4 \%$, respectively. Postirradiation annealing resulted in average value of $53,000 \mathrm{psi}$ and $13.2 \%$.

Since September, similar tube-burst tests at $600,700,750$, 800 , and $900^{\circ} \mathrm{C}$ indicate that a nonrecoverable loss of ductility, attributed to the presence of helium from $(n, \alpha)$ reactions, persists at temperatures above $700^{\circ} \mathrm{C}$. The comparative data are presented in Table II. Between 700 and $750^{\circ} \mathrm{C}$ the extent to which ductility is recovered on annealing changes definitely. In tests at $700^{\circ} \mathrm{C}$ and lower, the $900^{\circ} \mathrm{C}$ anneal has resulted in complete recovery of ductility.

The rupture strengths of specimens annealed after irradiation tend to remain slightly greater at 600 and $700^{\circ} \mathrm{C}$ than the rupture strengths of unirradiated controls at the se temperatures, but to be less at $800^{\prime \prime}$ and $900^{\circ} \mathrm{C}$ than in the case of the controls. 
TABLE II. Effect of Postirradiation Annealing on Strength and Ductility of EBR-II Fuel Cladding (Type 304L)

\begin{tabular}{|c|c|c|c|c|c|c|}
\hline \multirow[b]{2}{*}{$\begin{array}{c}\text { Test } \\
\text { Temperature } \\
\left({ }^{\circ} \mathrm{C}\right)\end{array}$} & \multicolumn{2}{|c|}{ Unirradiated } & \multicolumn{2}{|c|}{ Irradiated } & \multicolumn{2}{|c|}{$\begin{array}{c}\text { Irradiated and } \\
\text { Annealed }\end{array}$} \\
\hline & $\begin{array}{l}\text { Rupture } \\
\text { Strength } \\
\text { (psi) }\end{array}$ & $\% \Delta D / D$ & $\begin{array}{l}\text { Rupture } \\
\text { Strength } \\
\text { (psi) }\end{array}$ & $\% \Delta D / D$ & $\begin{array}{l}\text { Rupture } \\
\text { Strength } \\
\text { (psi) }\end{array}$ & $\% \Delta \mathrm{D} / \mathrm{D}$ \\
\hline 600 & 42,500 & 13.8 & $\begin{array}{l}59,100 \\
63,400 \\
65,700 \\
67,100 \\
64,300\end{array}$ & $\begin{array}{l}0.3 \\
0.6 \\
0.2 \\
1.2 \\
1.7\end{array}$ & $\begin{array}{l}45,000 \\
44,800 \\
44,600\end{array}$ & $\begin{array}{l}13.7 \\
12.1 \\
12.7\end{array}$ \\
\hline 700 & 33,800 & 11.1 & $\begin{array}{l}35,200 \\
40,700 \\
42,800 \\
41,600 \\
37,000\end{array}$ & $\begin{array}{l}8.8 \\
1.3 \\
3.6 \\
5.0 \\
1.5\end{array}$ & $\begin{array}{l}35,800 \\
37,200\end{array}$ & $\begin{array}{l}12.9 \\
12.3\end{array}$ \\
\hline 750 & & & & & $\begin{array}{l}25,700 \\
25,700\end{array}$ & $\begin{array}{l}2.0 \\
1.8\end{array}$ \\
\hline 800 & $\begin{array}{l}27,600 \\
29,400\end{array}$ & $\begin{array}{l}13.5 \\
16.7\end{array}$ & $\begin{array}{l}23,000 \\
21,800 \\
23,400 \\
24,100\end{array}$ & $\begin{array}{l}3.9 \\
1.7 \\
2.2 \\
3.3\end{array}$ & $\begin{array}{l}18,400 \\
20,000\end{array}$ & $\begin{array}{l}1.0 \\
1.7\end{array}$ \\
\hline 900 & $\begin{array}{l}19,300 \\
19,300\end{array}$ & $\begin{array}{l}15.8 \\
19.5\end{array}$ & $\begin{array}{l}14,900 \\
14,700 \\
13,800 \\
14,500 \\
14,500\end{array}$ & $\begin{array}{l}4.6 \\
2.2 \\
2.9 \\
3.2 \\
3.6\end{array}$ & $\begin{array}{l}17,200 \\
15,900 \\
14,500 \\
15,200 \\
15,600\end{array}$ & $\begin{array}{l}5.7 \\
3.1 \\
0.9 \\
3.2 \\
3.3\end{array}$ \\
\hline
\end{tabular}

Helium generation in Type 304 stainless steel is not apt to be a problem under present operating conditions in EBR-II, for the effects of the helium become evident only above $700^{\circ} \mathrm{C}$. The ductility losses due to atomic displacements are important. The capability of lower-temperature anneals, say at $500^{\circ} \mathrm{C}$, for removal of any appreciable number of atomic displacements will therefore be determined.

6. Fuel Cycle Facility (FCF)

a. Program to Increase Reactor Fuel Production. In order to meet increasing requirements for reactor fuel, needed to attain a higher reactor plant factor, plans are being prosecuted to expand significantly the FCF 
operating and analytical staff and to provide corresponding auxiliary personnel, to procure certain additional equipment, and to effect minor modifications in the facility. which will facilitate operations. In addition, plans are being developed for the commercial procurement of fuel for the reactor, for its processing off-site, and for the interim fabrication of unirradiated fuel elements at the EBR-II site other than in-cell. Implementation of these latter programs must await the approval of the AEC.

(i) Equipment Procurement. To speed operations and minimize downtime for repair in the FCF and its analytical facilities, procurement of the following typical equipment is planned or under way: additional master-slave and electromechanical manipulators, a skulloxidation furnace, fuel-element-bonding furnaces, fuel-storage and -transfer units, and other minor equipment. The utility of an emission spectrograph, capable of handling irradiated material for rapid analyses of minor fuel-alloy impurities, is also being studied with a view to such an installation.

(ii) Facility Modifications. Modifications of FCF and its auxiliary facilities which are planned to permit increased in-cell subas sembly production, and to increase the reliability of facility operation, include the following:

1. a manipulator decontamination and repair area (to be provided on the cell roof);

2. a process equipment decontamination and repair area in the FCF basement, to function in connection with the Transfer Cell Access Door, now being installed;

3. increased storage capacity for radioactively hot subassemblies in transit to or from the reactor;

4. an improved sample-transfer system (pneumatic) to connect the FCF with the analytical hot cells.

\section{(iii) Commercial Procurement of EBR-II Driver Fuel. A} specification suitable for the commercial procurement of EBR-II driver fuel elements has been prepared and submitted to the AEC for review along with a procurement plan. Prospective vendors have been visited to as certain their capabilities and interest, and information on fabrication techniques has been furnished to potential vendors.

Since commercial procurement will increase the FCF and reactor inventory beyond that which can be stored or processed, discussions have been held with the staff of the Idaho Chemical Processing Plant concerning the capability of this facility for storage and reprocessing of EBR-II fuel. To accomplish such storage or reprocesising, transfer 
casks will be required. Off-site reprocesșing will increase the availability of the FCF for the experimental irradiation program and ultimately permit its utilization for the development and demonstration of processes for other fuels.

(iv) Interim Fabrication of Unirradiated Fuel. As an interim measure, pending the availability of driver fuel from commercial sources, consideration is being given to providing facilities at the EBR-II site for casting, assembly, welding, and testing of fuel elements prepared from unirradiated alloy, to effect the most rapid production increase. In order to facilitate this, existing space in the FCF and in the ITF (Inspection and Test Facility) would be used. The ITF is also being proposed for assembly of commercially procured fuel elements into reactor subassemblies as well as its present use in the EBR-II experimental fuels irradiation program.

b. Hot Fuel Examination Facility. Design studies are under way for a Hot Fuels Examination Facility (HFEF) which it is proposed to attach to the FCF to provide for the safe and expeditious handling of EBR-II irradiation experiments, and principally for nondestructive testing and reinsertion of fuels in the reactor. The main cell will be located as an extension at the northwest corner of the FCF and will provide a radiationshielded, inert-atmosphere space for subassembly transfer and equipment repair, as well as for the disassembly and reassembly, dimensioning, radiography and eddy-current examination, subassembly testing, sample preparation, and physical testing of experimental fuel and material specimens which have been irradiated in EBR-II. An auxiliary decontamination cell will be provided, along with a hot shop and a shielded mechanical and storage area.

\section{c. FCF Operations}

(i) ' Summary of Production. A summary of production operations is contáined in Table III.

(ii) Effect of Sodium-removal Operation. The reinsertion of experimental ir radiation assemblies into the reactor will normally involve reinserting stainless steel capsules from which adhering sodium has been removed by treatment with humid air and with water. To assure that no significant deleterious effects on the stainless steel will occur as a result of the sodium-removal operation, a test is being carried out in which fuel elements, from which sodium has been removed by the normal procedure (except for double washing), were irradiated and then removed for detailed examination of the cladding. These elements were contained in subassembly C228, removed from the reactor at the end of Run No. 22. "Close examination of six elements using a periscope, revealed sound welds and no abnormal surface conditions. Staining and residue on the lower ends of the elements were normal. Specimens of the cladding were obtained for metallographic examination. 
TABLE III. Production Summary for December 1966

Subas semblies received:

Subas semblies dismantled:

Subassemblies fabricated:

Subassemblies transferred to reactor:

Elements decanned:

Melt refining:

Pour Yield (av):

Injection casting runs:

Elements processed:

Accepted:

Rejected:

Elements welded:

Accepted:

Rejected:

Elements bonded and tested (completed runs):

Accepted:

Rejected:

Subassemblies subjected to surveillance:
23

16

$13^{(a)}$

4

1623

9 irradiated 4 recycle 92.8

93.0

13

1232

102

868

28

1090

56

4

(a) Plus 6 additional subassemblies containing flux wires, fabricated from unirradiated fuel for reactor flux measurements

B. Physics Development

1. $\underline{\mathrm{ZPR}-3}$

a. Assembly 48. The results of the heterogeneity experiments conducted on Assembly 48 last month are given here. Assembly 48 is a 400-liter, plutonium-fueled core of simple composition, with a degraded neutron spectrum similar to those in some anticipated large power-reactor cores.

Both fuel-bunching experiments and sodium-void experiments were run. Figures 2 and 3 show the locations of the drawers used in the experiments. The central core measurements were made in the front 4 in. of the drawers marked $A$ and $B$. Measurements at the axial core edge were made in the outer 4 in. of core material in the drawers marked $A$ and $B$. Measurements at the radial core edge were made in the front 4 in. of the drawers marked $C$ and D. Figure 4 is an end view of the arrangement of material in the 4 -in. section of the core drawers used in the experiments.

The results of the heterogeneity experiments are listed in Table IV. The effect of bunching and unbunching the fuel columns was measured at the core center. The effect of fuel bunching was also measured at the axial core edge. 


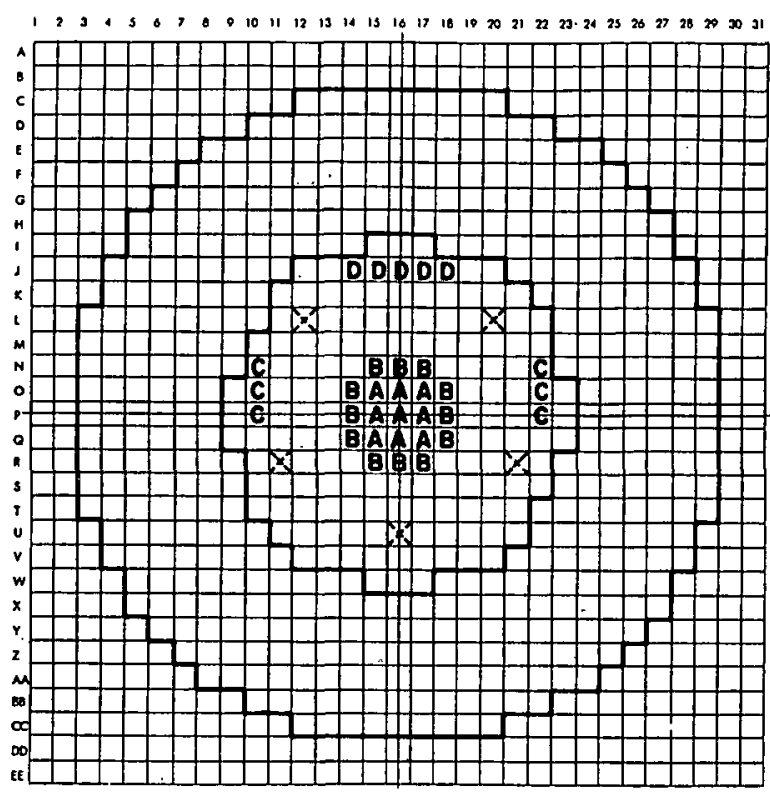

Fig. 2. Drawers Used in Heterogenity Experiments in Half No. 1 of Assembly 48 of ZPR-3

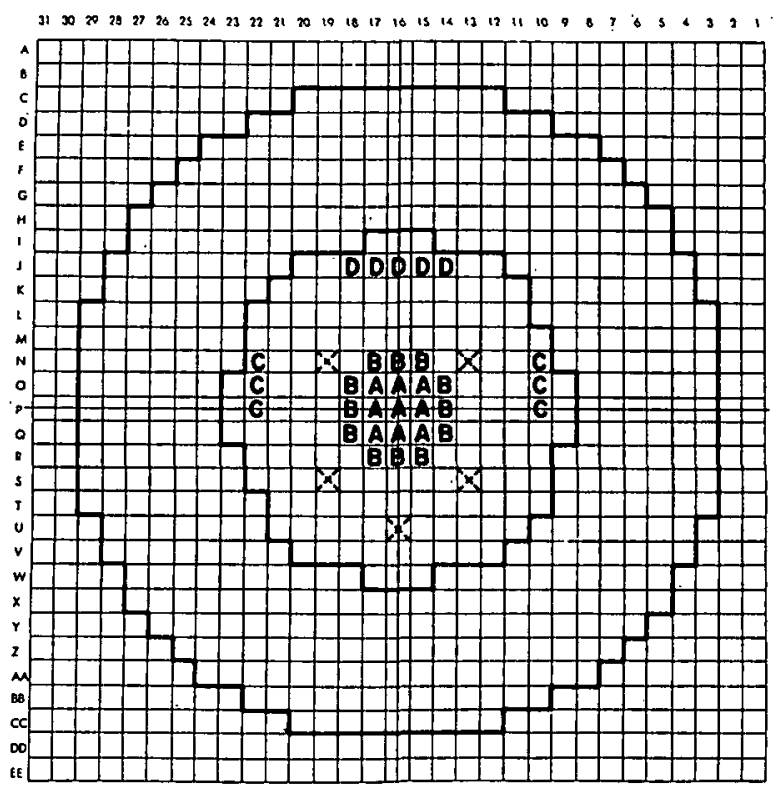

Fig. 3. Drawers Used in Heterogeneity Experiments in Half No. 2 of Assembly 48 of ZPR-3

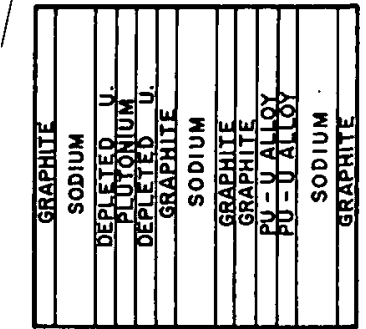

o. NORMAL FUEL LOADING

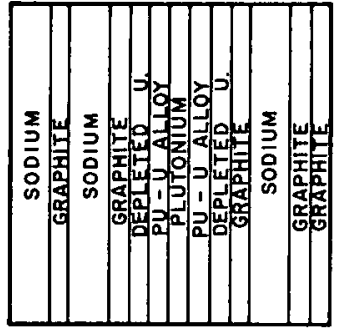

b. BUNCHED FUEL LOADING

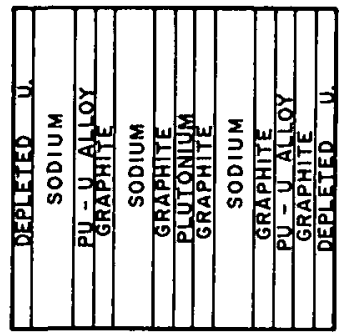

c. UNBUNCHED FUEL LOADING
Fig. 4

Material Arrangements in Core Drawers for Heterogeneity Experiments with ZPR-3 Assembly 48

TABLE IV. Results of Heterogeneity Experiments in Assembly 48

\begin{tabular}{|c|c|c|c|c|c|c|c|c|c|c|}
\hline $\begin{array}{l}\text { No. of } \\
\text { Drawers }\end{array}$ & Experiment & $\begin{array}{c}\text { Core } \\
\text { Location }\end{array}$ & $\begin{array}{c}\text { Drawer } \\
\text { Designation }\end{array}$ & $\begin{array}{c}\text { Change in } \\
\text { Reactivity (Ih) }\end{array}$ & $\begin{array}{l}\text { No. of } \\
\text { Drawers }\end{array}$ & $\begin{array}{c}\text { Fuel } \\
\text { Configuration }\end{array}$ & $\begin{array}{l}\text { Core } \\
\text { Location }\end{array}$ & $\begin{array}{c}\text { Drawer } \\
\text { Designation }\end{array}$ & $\begin{array}{l}\text { Sodium } \\
\text { Removed } \\
\text { (kg) }\end{array}$ & $\begin{array}{c}\text { Reactivity } \\
\text { Change } \\
\text { (Ih/kg) }\end{array}$ \\
\hline \multicolumn{5}{|c|}{ Fuel Experiments ${ }^{(a)}$} & \multicolumn{6}{|c|}{ Sodium-void Measurements(a) } \\
\hline 9 & Bunching & Center. & 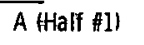 & $16.1 \pm 1.0$ & 18 & Normal & Center & $\bar{A}$ & 1.32 & $7.9 \pm 0.8$ \\
\hline 9 & Bunching . & Center & A (Half $\# 2)$ & $17.1 \pm 1.0$ & 24 & Normal & Center & B & 1.76 & $3.2 \pm 0.6$ \\
\hline 24 & Bunching & Center & B & $\cdot 41.7 \pm 1.0$ & 42 & Normal & Center & $A$ and $B$ & 3.08 & $5.2 \pm 0.3$ \\
\hline 42 & Bunching & Center & $A$ and $B$ & $75.2 \pm 1.0$ & 42 & Bunched & Center & $A$ and $B$ & 3.08 & $3.1 \pm 0.3$ \\
\hline 42 & Bunching & Axial Edge & $A$ and $B$ & $16.8 \pm 1.0$ & 42 & Unbunched & Center & $A$ and $B$ & 3.08 & $5.7 \pm 0.3$ \\
\hline 18 & Unbunching & Center & A & $-8.3 \pm 1.0$ & 42 & Standard & Center & $\dot{A}$ and $B$ & $3.08^{\circ}$ & $5.6 \pm 0.3$ \\
\hline 24 & Unbunching & Center & B & $-11.5 \pm 1.0$ & 42 & Normal & Axial Edge & $A$ and $B^{-}$ & 3.08 & $-20.7 \pm 0.3$ \\
\hline \multirow[t]{6}{*}{42} & Unbunching & Center & $A$ and $B$ & $-20.0 \pm 1.0$ & 42 & Bunched & Axial Édge & $A$ and $B$ & 3.08 & $-23.6 \pm 0.3$ \\
\hline & & & & & 42 & Standard & Axial Edge & $A$ and $B$ & 3.08 & $-20.5 \pm 0.3$ \\
\hline & & & & & 42 & Bunched (15 in.) & Axial Edge & $A$ and $B$ & 3.08 & $-23.5 \pm 0.3$ \\
\hline & & & & & 12 & Standard & Radial Edge & C & 0.88 & $-17.6 \pm 1.1$ \\
\hline & & & - & & 10 & Standard & Radial Edge & $D$ & 0.73 & $-19.6 \pm 1.4$ \\
\hline & & & & & 22 & Standard & Radial Edge & $C$ and $D$ & 1.61 & $-18.5 \pm 0.6$ \\
\hline
\end{tabular}

(a) All measurements made in both halves of reactor, except where stated otherwise. 
The change in reactivity due to the removal of sodium was measured at the center, axial edge, and radial edge of the core. This was done in the various fuel-loading configurations shown in Fig. 4.by removing the cans of sodium and replacing them with an amount of stainless steel equal to that in the sodium cans. The "standard" fuel configuration listed in Table IV is the same as the "normal" fuel loading except that the 1/4-in. Pu-U alloy fuel column had not been replaced with the two 1/8-in. columns used in the fuel bunching and unbunching experiments. Sodium-void measurements were made in both the "standard" and "normal" fuel configurations because the substitution of two $1 / 8$-in. columns for one $1 / 4$-in. column of fuel reduced the total $\mathrm{Pu}^{239}$ and $\mathrm{Pu}^{241}$ loading by $\sim 0.7 \mathrm{~kg}$ in the $42-\mathrm{drawer}$ central and axial core-edge experimental region. During the sodium-void measurements at the axial core edge, a change in the worth of sodium between the "normal" and "bunched" fuel configurations was noted. To determine if this change in reactivity was due to neutron streaming from the 11-in. portion of the fuel columns not bunched during the bunching measurements, the experiment was repeated in a "standard" fuel loading and a loading in which the entire 15-in. columns of fuel were bunched. The results indicate that the change in worth of the sodium in this region is due to fuel bunching and not to neutron streaming.

b. Assembly 48A. On December 1, a series of experiments was begun for Pacific Northwest Laboratories (PNL) in connection with the FFTF project. Argonne National Laboratory, through the AEC, is providing the critical assembly experiments in support of the reactor being designed by the FFTF group. This initial set of experiments, mutually agreed to by ANL and PNL, is to run for eight weeks, and will provide data necessary for the development of calculational techniques to be used in the design of the FFTF reactor, particularly in the area of control-rod designs. The core in Assembly 48 is being used since the neutron spectrum is fairly representative of that expected in the FFTF reactor.

These experiments consist primarily of measurements of control-rod worths, both centrally and in the reflector. The FFTF design will utilize a reflector of medium atomic weight (largely nickel), and a quadrant of such a reflector will replace the uranium reflector on Assembly 48. However, initial experiments will be performed with the full uranium reflector to provide comparative data with reflectors of both heavy and medium atomic weights. With both reflectors the emphasis will be on control-rod worths (poison rod experiments), reactivity-traverse measurements. with small samples, and reaction-rate traverses.

The poison rod measurements and the axial reactivity coefficient sample traverses have been made with the depleted uranium blanket still in place. The loading is now under way to replace two segments of the depleted uranium blanket with an Inconel reflector of the type that might be used on the EFTF reactor. The remaining experiments will be conducted with the new blanket-reflector configuration. 
Figure 5 shows the $\mathrm{B}_{4} \mathrm{C}$ arrangement in several poison rod mockups. The worths of these rods, which were $54 \mathrm{in}$. long, were measured at the axis of the core and blanket by replacing a drawer filled with eight 1/4-in. columns of sodium. The normal rod mockup with enriched $\mathrm{B}_{4} \mathrm{C}$ was measured in steps through the blanket and core to its full 54 in. No other pois on rod mockups were measured in steps. The effect of bunching the enriched $\mathrm{B}_{4} \mathrm{C}$ was measured by replacing the reference loading with the bunched loading. The effect of enrichment was measured by replacing the enriched $\mathrm{B}_{4} \mathrm{C}$ with natural $\mathrm{B}_{4} \mathrm{C}$ in the normal loading. The results are given in Table V. Subcritical multiplication techniques were used to make the measurements. The error is estimated to be $\pm 2 \%$.

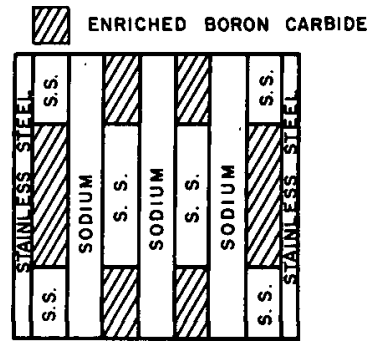

a. NORMAL

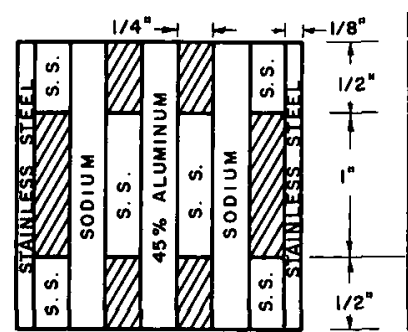

b. REFERENCE FOR BUNCHING

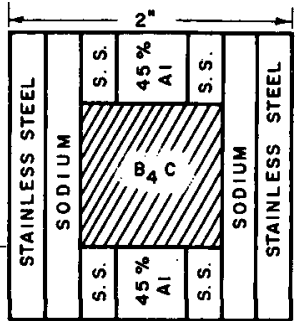

c. BUNCHED
Fig. 5

Cross-sectional View of Drawer Loadings Showing $\mathrm{B}_{4} \mathrm{C}$ Arrangement in Poison Rod Mockups : for Assembly $48 \mathrm{~A}$

TABLE V. Results of Measurements with Central Poison Rod Mockup in Assembly 48A

\begin{tabular}{|c|c|c|c|c|}
\hline \multirow[b]{2}{*}{ Rod Insertion (in.) } & \multicolumn{4}{|c|}{ Reactivity Change for Rod Mockups (Ih) } \\
\hline & $\begin{array}{l}\text { Normal } \\
\text { Enriched } \mathrm{B}_{4} \mathrm{C}\end{array}$ & $\begin{array}{c}\text { Normal } \\
\text { Natural } \mathrm{B}_{4} \mathrm{C}\end{array}$ & $\begin{array}{c}\text { Reference } \\
\text { Enriched } \mathrm{B}_{4} \mathrm{C}\end{array}$ & $\begin{array}{c}\text { Bunched } \\
\text { Enriched } \mathrm{B}_{4} \mathrm{C}\end{array}$ \\
\hline 0 (Blanket Edge) & 0 & 0 & 0 & 0 \\
\hline 8 & -2.9 & & & \\
\hline 12 (Core Blanket) & -26.9 & & & \\
\hline 19 & -288 & & & \\
\hline 27 (Core Midplane) & -894 & & & \\
\hline 35 & -1487 & & & \\
\hline 42 (Core Blanket) & -1723 & & & \\
\hline 54 (Blanket Edge) & -1742 & -747 & -1737 & -1531 \\
\hline
\end{tabular}

An axial traverse drive mechanism was installed to make traverses with reactivity coefficient samples. The traverses were made through a half-inch guide tube placed in the central core drawers. The materials measured were 2 -in.-long cylindrical samples of plutonium, enriched uranium, depleted uranium, boron, and tantalum. Also, stainless steel was measured so that a correction for the sample container could be made. The empty sample carrier was also run as a reference for the material samples. The servo-control rod (autorod) was calibrated and used for measuring the reactivity changes of the samples. The results of the traverse runs are being analyzed. 
2. $\underline{\mathrm{ZPR}-6}$

Reaction-rate traverses of $\mathrm{U}^{235}$ and $\mathrm{U}^{238}$ were done in the radial and axial directions in ZPR-6 Assembly 5. These results are shown in Fig. 6. The extrapolation to zero fluxes results in an equivalent bare radius of $92 \mathrm{~cm}$. The radial traverses do not fit a zero-order Bessel function.

Experiments were performed with an accelerator-type pulsed neutron source in Assembly 5. Tritium target for the $T(d, n)$ He reaction was placed in the center of the core.

A pulse width of about $1.5 \mu$ sec was used to study the decay of neutron bursts. $\mathrm{U}^{235}$ and $\mathrm{U}^{238}$ fission chambers were used as detectors at different radial locations in the midplane of the reactor. At two locations (near the core center and near the core-blanket boundary) the transients immediately following the pulse were studied in detail with $0.15-\mu$ sec-width pulses using a $\mathrm{U}^{235}$ chamber. All decay measurements were made with the reactor subcritical between 0.1 and $2 \% \Delta \mathrm{k} / \mathrm{k}$.

A proton-recoil counter was placed in the core to measure the neutron spectrum at different time intervals after the pulse, using a pulse width of $1.5 \mu \mathrm{sec}$. The proton-recoil counter was gated on for $10 \mu \mathrm{sec}$ or $3 \mu$ sec at different times after the pulse.

The neutron intensity emerging from a beam hole which was created by removing four central drawers from the core was measured with a $\mathrm{U}^{235}$ fission chamber.

A detailed evaluation of all the pulsed experiments will be made.

\section{ZPR -9}

The results of the central worth measurements made in $Z P R-9$ Assembly 12, obtained from period measurements, are given in Table VI. Assembly 12 is a small zoned assembly designed to have a central neutronenergy spectrum similar to those of Assemblies $4 Z$ and 5 of ZPR- 6 . The constancy of the ratios of worth in Assembly 12 to worth in Assembly 5 is an indication that the spectra are well matched. The deviation in this ratio for the light scattering materials, such as carbon and beryllium, indicates that a perfect match has not been achieved. Because of the general shape of the adjoint function in this type of core, a deviation of less than $1 \%$ in this function can cause changes as great as $100 \%$ in the worth of a pure scattering sample. The scattering materials are therefore a very sensitive test of the spectral match. In the case of sodium, however, the small signal caused an uncertainty in the ratio of $\sim 30 \%$. It therefore gives only limited information on the spectral match; additional sodium measurements are underway to improve the precision of the measurement of this important quantity. 


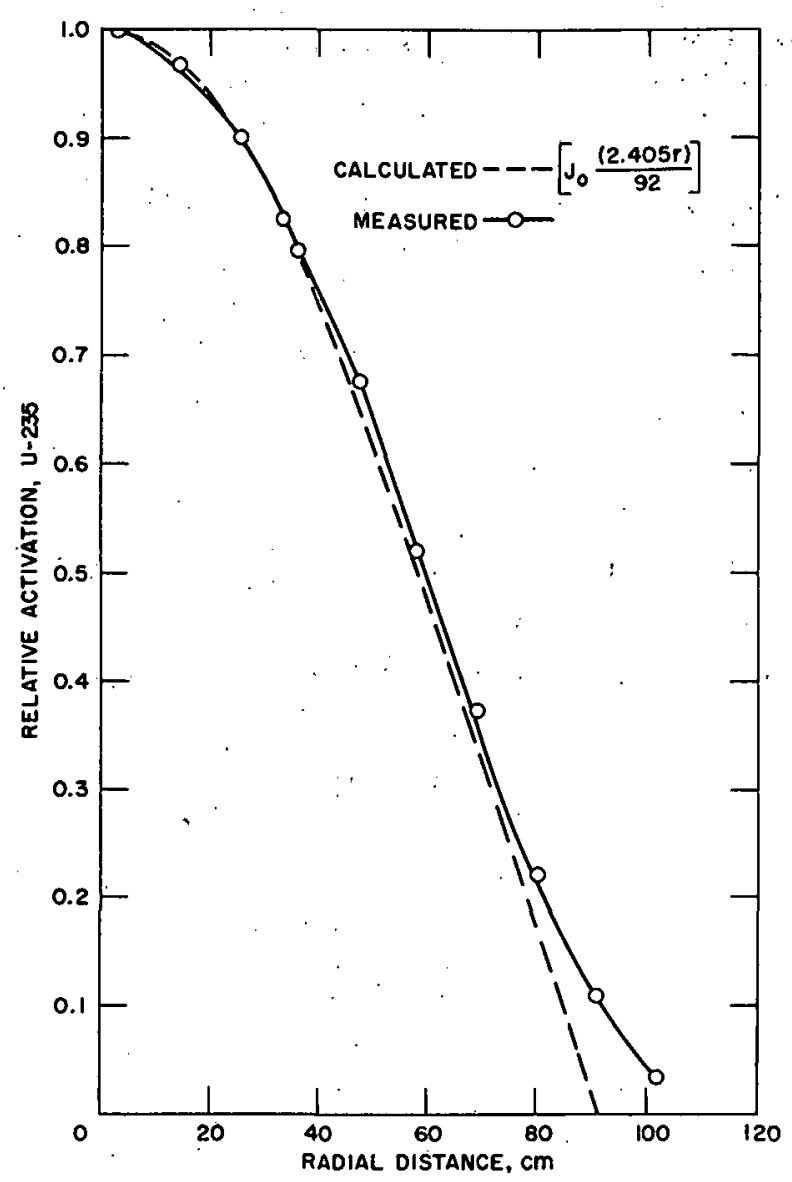

Fig. 6a. Reaction-rate Traverse of $\mathrm{U}^{235}$ in the Radial Direction of ZPR-6 Assembly 5

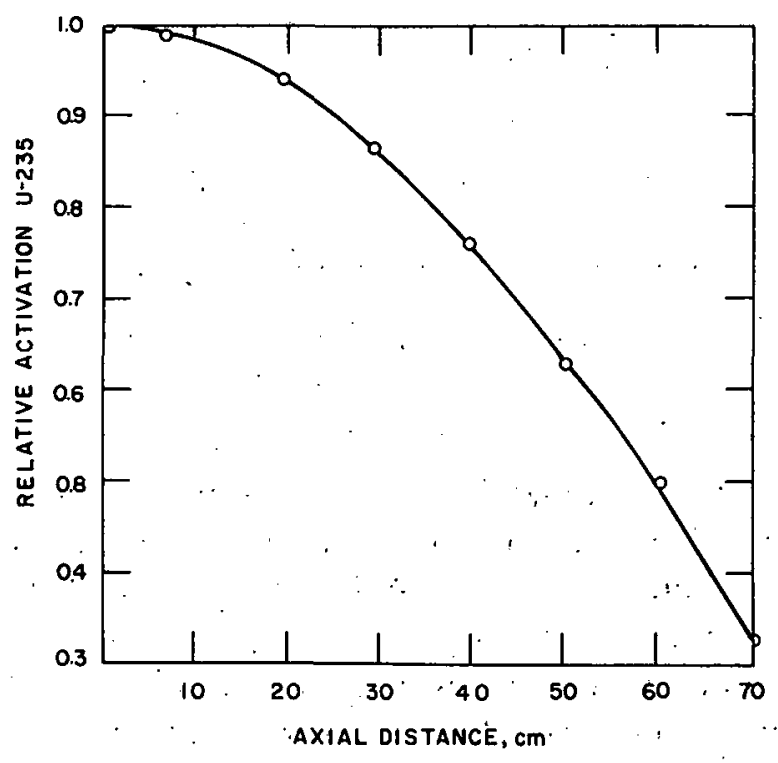

Fig. 6c. Reaction-rate Traverse of $U^{235}$ in the Axial Direction of ZPR-6 Assembly 5

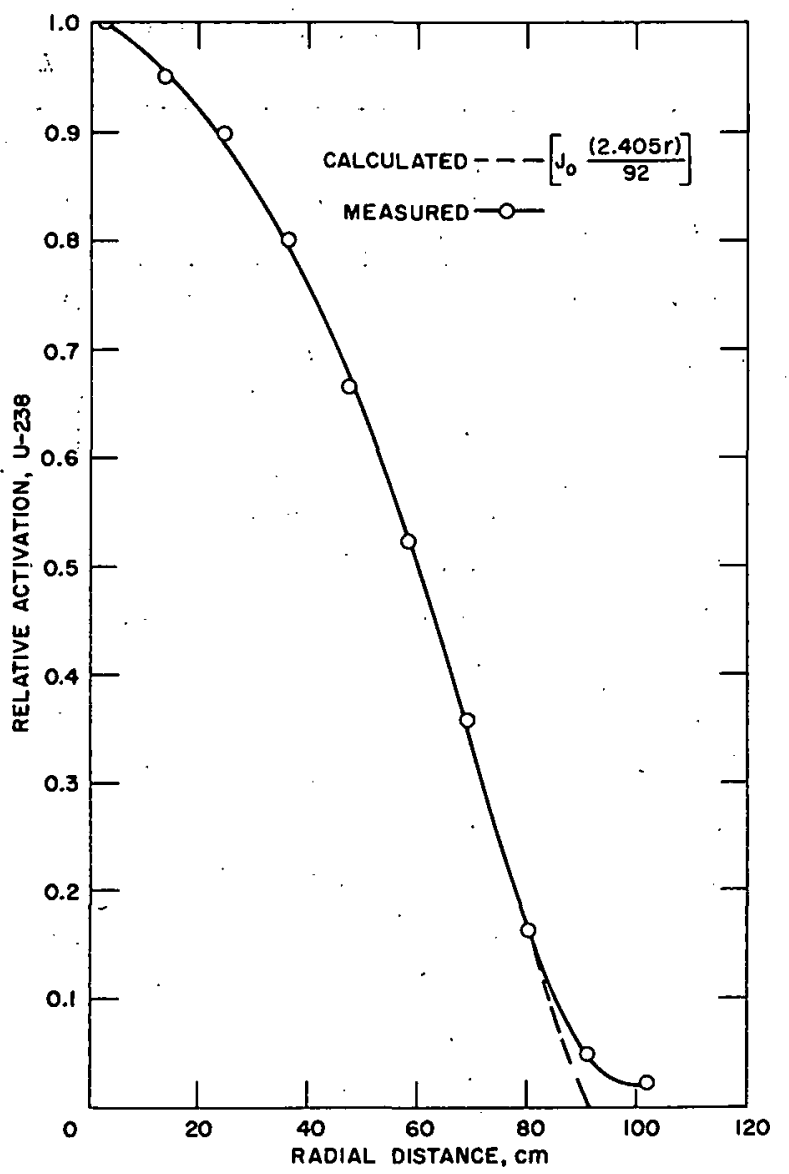

Fig. 6b. Reaction-rate Traverse of $U^{238}$ in the Radial Direction of ZPR-6 Assembly 5

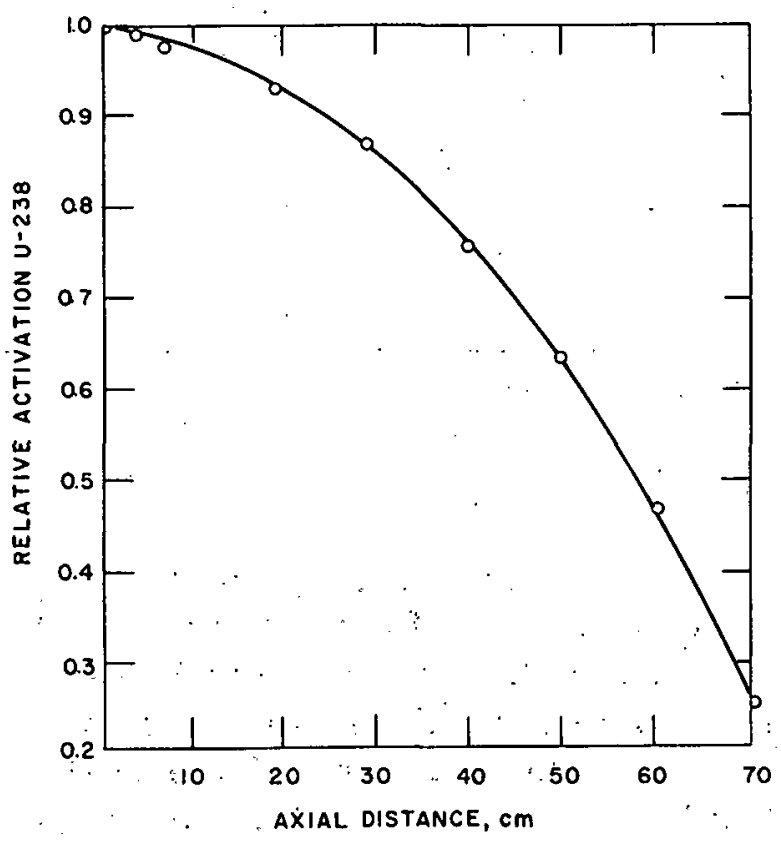

Fig. 6d. Reaction-rate Traverse of $U^{238}$ in the Axial Direction of ZPR-6 Assembly 5 
TABLE VI. Central Worth Measurements in ZPR-9.Assembly 12 $(1 \% \delta \mathrm{k} / \mathrm{k}=45 \mathrm{l} .2 \mathrm{Ih})$

\begin{tabular}{|c|c|c|c|c|c|c|}
\hline Sample & $\begin{array}{l}\text { Sample } \\
\text { Weight } \\
\text { (g) }\end{array}$ & $\begin{array}{l}\text { Can } \\
\text { Weight } \\
\text { (g) }\end{array}$ & $\begin{array}{l}\text { Gross } \\
\text { Worth } \\
\text { (Ih) }\end{array}$ & $\begin{array}{c}\text { Net Worth } \\
\text { (Ih) }\end{array}$ & $\begin{array}{l}\text { Net Worth } \\
(\mathrm{Ih} / \mathrm{kg})\end{array}$ & $\begin{array}{l}\text { Ratio of } \\
\frac{\text { Worth in Assembly } 12}{\text { Worth in Assembly } 5}\end{array}$ \\
\hline Polyethylene & 23.973 & Bare & +9.539 & $+9.539 \pm 0.010$ & $+397.9 \pm 0.5$ & - \\
\hline Polyethylene & 58.98 & Bare & +26.155 & $+26.155 \pm 0.015$ & $+443.5 \pm 0.3$ & 1.368 \\
\hline $\mathrm{Be}$ & 114.308 & Bare & +1.395 & $+1.395 \pm 0.010$ & $+12.208 \pm 0.087$ & 1.235 \\
\hline $\mathrm{B}^{10}$ & 29.29 & 55.73 (SS) & -32.731 & $-32.589 \pm 0.015$ & $-1112.6 \pm 0.6$ & 1.393 \\
\hline C & 102.01 & Bare & +0.161 & $+0.161 \pm 0.011$ & $+1.578 \pm 0.11$ & 0.888 \\
\hline $\mathrm{Na}$ & 51.38 & 54.52 (SS) & -0.210 & $-0.0707 \pm 0.0103$ & $-1.376 \pm 0.20$ & 1.713 \\
\hline Al & 166.9 & Bare & -0.428 & $-0.428 \pm 0.010$ & $-2.564 \pm 0.060$ & 1.427 \\
\hline $\mathrm{Fe}$ & 488.0 & Bare & -1.022 & $-1.022 \pm-0.010$ & $-2.095 \pm 0.020$ & - \\
\hline SS & 480.98 & Bare & -1.137 & $-1.137 \pm 0.010$ & $-2.365 \pm 0.021$ & 1.389 \\
\hline SS can & 72.378 & Bare & -0.184 & $-0.184 \pm 0.010$ & $-2.542 \pm 0.138$ & - \\
\hline $\mathrm{Ni}$ & 546.0 & Bare & $\cdot-1.634$ & $-1.634 \pm 0.010$ & $-2.993 \pm 0.018$ & 1.441 \\
\hline $\mathrm{Nb}$ & 481.2 & $30.10 .(\mathrm{SS})$ & -5.406 & $-5.329 \pm 0.015$ & $-11.074 \pm 0.031$ & 1.389 \\
\hline Mo & 599.0 & Bare & -4.826 & $-4.826 \pm 0.010$ & $-8.057 \pm 0.017$ & 1.413 \\
\hline $\mathrm{Ta}$ & 924.7 & 27.54 (SS) & -16.698 & $-16.628 \pm 0.015$ & $-17.982 \pm 0.016$ & 1.386 \\
\hline W & 1108.0 & Bare & -8.133 & $-8.133 \pm 0.010$ & $-7.340 \pm 0.010$ & 1.404 \\
\hline $\mathrm{U}^{235}$ & $\begin{array}{c}18.11 \\
(\text { Total) } \\
16.87 \\
\left(\mathrm{U}^{235}\right)\end{array}$ & $72.378(\mathrm{SS})$ & +0.993 & $+1.183 \pm 0.015$ & $+70.12 \pm 0.88$ & 1.399 \\
\hline$U^{235}$ & $\begin{array}{c}59.40 \\
(\text { Total }) \\
55.32 \\
\left(\mathrm{U}^{235}\right)\end{array}$ & 55.44 (SS) & +3.526 & $+3.691 \pm 0.015$ & $+66.72 \pm 0.27$ & - \\
\hline $\mathrm{U}^{238}$ & 1153.8 & Bare & -5.398 & $-5.398 \pm 0.010$ & $-4.679 \pm 0.009$ & 1.398 \\
\hline $\mathrm{Pu}$ & $\begin{array}{r}148.36 \\
(T \text { otal }) \\
113.34 \\
\left(\mathrm{Pu}^{239}\right) \\
5.34 \\
\left(\mathrm{Pu}^{240}\right) \\
0.54 \\
\left(\mathrm{Pu}^{241}\right)\end{array}$ & $\begin{array}{l}22.27(\mathrm{SS}) \\
6.85(\mathrm{AI})\end{array}$ & +11.019 & $+11.094 \pm 0.20$ & $+93.05 \pm 1.7(\dot{a})$ & 1.336 \\
\hline
\end{tabular}

(a) Value is for plutonium mixture.

\section{ZPPR}

The overall construction of the ZPPR facility is on schedule. All foundation posts for the reactor cell have been grouted in place. The foundation of the service wing has been poured except for the AFSR wing. The floor slab, the east wall, and the interior separation wall of the vault-workroom area have been poured. Seventy-five percent of the north and south walls has been completed. The counting-room concrete including the roof has been poured. The floor slab of the control room has been formed and poured. The excavation for the foundation of the AFSR has commenced. 
The present status of the reactor components is as follows:

a. Items Completed. Completed items that have been inspected, accepted, and presently stored at the Idaho Division are: bed and tables, fuel control and safety rod drives, matrix tubes, louvers for the reactor cooling system, tube plug clamping as semblies, reactor frame, pit bumpers, ramp assembly, platform support bracket, seismic switch, beta-gamma air particulate monitors, area gamma monitors, nuclear instrumentation, and reactor control consoles and cabinets.

b. Matrix Drawers: The vendor, Mechanical Products Manufacturing Company, Seattle, Wash., has supplied the following acceptable matrix drawers: 100 special tab front drawers, 1677 regular front drawers, and 2146 back drawers. Approximately 400 regular front drawers remain to be finished as well as 48 special narrow drawers.

c. Poison Safety Rod Drives: All parts for the first rod drive have been received or fabricated. Assembly of this first rod for check out has begun.

d. Reactor Knees. An ANL representative inspected the knees at the vendor.'s plant, McCauley Foundry, Berkeley, California. The surfaces and dimensions were satisfactory. Relocation of the plenum mounting holes on one set of knees was required.

e. Personnel Shields: The bids for the reactor personnel shields have been evaluated and have been sent to $\mathrm{AEC}-\mathrm{CH}$ for approval.

f. Matrix Alignment: The bid packages on the matrix alignment plates have been sent out. The due date on bid packages is January 17.

g. Source Drives. Work is continuing.

h. Rod-drive Mounting Plates. One rod-drive mounting plate was rejected because of excessive unrepairable cracks around the poison rod drive mounting holes and the center experimental hole. Thé vendor was instructed to recast a new plate. The second plate was also conditionally rejected due to some cracks and voids. This plate could be repaired. The vendor was given the choice of repairing it satisfactorily or recasting the plate. An extension of six weeks for delivery was given the vendor.

i: Drawer Springs: The resubmitted samples were found acceptable. The vendor was instructed to proceed with the fabrication of the drawer springs.

j. Matrix Tie-down. Fabrication of the reactor matrix tie-down is continuing. 
k. Loading Platform. An ANL representative inspected the completed loading platform at the vendor's plant. The platform was acceptable and has been painted. It is now being crated for shipment.

1. Reactor Plenum Assemblies. The fabrication of the plenum assemblies is continuing. The samples of Neoprene plugs were reviewed and accepted. The vendor was instructed to begin fabrication of the plugs.

m. Pit Conveyor. The conveyor was sent back to the vendor to correct the location of holes.

n. Fuel Control and Safety Rod Drawers and Ball Joint Assemblies: The control drawers have been Scottsonized. The monoballs for the joints have been received. The units are being assembled.

o. Poison Safety Blades and Sheaths. A blade and sheath have been Scottsonized and are now being inspected for dimensional tolerances. Evaluation of these samples will be made by the vendor prior to processing the remaining units.

p. Boron Fabrication. The bid packages for the fabrication of boron into $\mathrm{B}_{4} \mathrm{C}$ are being processed in the Laboratory.

q. Stack Gamma Monitor: A service request for the mound area stack gamma air monitor has been is sued.

r. Reactor Control Cable Stand. Purchase items for the Reactor Control Cable Stand have been initiated. 


\section{Component Development}

1. Sodium Technology and Development

a. Sodium Analytical Laboratory. All components of a 1024-channel system for analyzing radioactive materials in sodium have been received except the phototube socket and preamplifier. A preliminary checkout of the equipment by the supplier has been completed.

Difficulties with the purification system for the glovebox atmosphere were found to be due to an inoperative solenoid valve on the discharge side of the oxygen-getter bed, consisting of hot copper turnings. During the regeneration cycle a hydrogen-helium gas mixture sweeps across the heated bed, reduces the copper oxide, and then flows out through the discharge valve. The jamming of the inoperative valve was due to an accumulation of iron oxide and possibly some copper oxide in sufficient quantity to interfere with its operation. The valve has been cleaned and reinstalled. The glovebox and purification system are again in operation. A filter will be installed in the line to prevent the reoccurrence of this problem.

b. Measurement of Sodium Quality. Installation of a new Sodium Analytical Loop is approximately 65\% complete. All line heaters and line thermocouples have been installed, and the cold-trap cooling system has been completed. The major work remaining to be done includes insulation, wiring, and vacuum-gas line hookup.

A modified flat-coiled resistance heater for the EBR-II

Primary Sodium System sample cup has been tested. Three sodium distillations made with this type of heater gave favorable low-current and high-temperature operation. The fabrication of this improved heater is much simpler, and the design will be incorporated in a new modified. sample cup.

\section{Materials Evaluation}

a. Effects of Sodium on Stainless Steels. Two coupons each of 304 stainless steel and $304 \mathrm{~L}$ stainless steel were soaked in sodium containing $\sim 20 \mathrm{ppm}$ oxygen for $9 \frac{1}{2}$ days at $1200^{\circ} \mathrm{F}$. Resistivity measurements made with the original material, after sodium treatment, and after soaking in Strauss reagent for two successive 30 -min periods gave values shown in Table VII.

Strauss reagent vigorously attacks chromium carbide precipitates located in the grain boundaries of the steel. These tests indicate that the embrittlement or extent of carbide precipitation in stainless steel resulting from its exposure to sodium at $1200^{\circ} \mathrm{F}$ is considerably greater for Type 304 stainless steel (with 0.06-0.08\% carbon) than for Type 304L (with $0.03 \%$ max carbon), the embrittlement being determined by increase in resistivity after treating the specimens in Strauss reagent. 
TABLE VII. Electrical Résistivity Values (ohm-cm) of Stainless Steels

\begin{tabular}{|c|c|c|c|c|c|c|}
\hline $\begin{array}{l}\text { Sample } \\
\text { No. }\end{array}$ & $\begin{array}{l}\text { Steel } \\
\text { Type }\end{array}$ & $\begin{array}{c}\text { Carbon Content }(\%) \\
\text { (nominal) }\end{array}$ & $\stackrel{\rho}{\text { Original }}$ & $\begin{array}{c}\rho \text { after } \\
\text { Sodium } \\
\text { Treatment }\end{array}$ & $\begin{array}{c}\rho \text { after } \\
30 \text { min in } \\
\text { Strauss Solution }\end{array}$ & $\begin{array}{c}\rho \text { after } \\
60 \text { min in } \\
\text { Strauss Solutiona }\end{array}$ \\
\hline 1 & $304 \mathrm{~L}$ & $0.03 \max$ & 70.7 & 71.3 & 71.3 & 71.3 \\
\hline 2 & $304 \mathrm{~L}$ & $0.03 \max$ & 73.4 & 74.3 & 75.1 & 75.6 \\
\hline 3 & 304 & 0.06 (by analysis) & 69.8 & 70.5 & 137.2 & $\begin{array}{l}\text { (Sample } \\
\text { Disintegrated) }\end{array}$ \\
\hline 4 & 304 & 0.07 (by analysis) & 74.9 & 74.6 & 98.4 & 97.6 \\
\hline
\end{tabular}

$\begin{array}{llr}\text { astraus s Solution: } & \text { Cupric Sulfate } & 30 \mathrm{~g} \\ & \text { Conc. } \mathrm{H}_{2} \mathrm{SO}_{4} & 55 \mathrm{ml} \\ & \text { Distilled Water } 870 \mathrm{ml} .\end{array}$

b. Wear Testing. In the area of wear testing to be performed in the CAMEL loop, a complete Falex wear test unit was assembled and mounted on a sodium-filled pot. A pair of Stellite 19B vee blocks was mounted in this unit in contact with a Carboloy $98 \mathrm{~B}$ shaft. The unit was checked out with the data-acquisition system which will be used to collect the data on rpm, motor torque, wear and wear rate, and temperature.

A test of the data-acquisition system demonstrated satisfactory collection of the significant parameters.

A program is being written so that the collected data can be translated into frictional coefficients. A comparison will be made of the frictional coefficients under sodium with those measured in inert gas. Data points will be examined over the temperature range from 300 to $1000^{\circ} \mathrm{F}$. A number of alloys have been received which will be used in future tests. The materials are being fabricated into vee blocks and shafts.

\section{Fuel Development}

1. Irradiation of Uranium-Plutonium Alloys

Jacket collapse above the U-Pu-Fs pin in each of three experimental EBR-II fuel elements* (see Progress Report for November 1966, ANL-7279, p. 23) was found on examination to have restrained the elongation of the fuel pins that was observed in 16 companion fuel elements with uncollapsed jackets.

Eighteen full-length fuel elements of U-Pu-Zr jacketed severally in tubing of $\mathrm{V}-20 \mathrm{w} / \mathrm{O} \mathrm{Ti}$, of Types 304 and 316 stainless steel, and of Hastelloy-X and - X-280 had last month attained a calculated maximum burnup of $4: 7 \mathrm{a} / \mathrm{o}$ at a maximum jacket temperature of $630^{\circ} \mathrm{C}$. The burnup of two additional rods operating at a maximum jacket temperature of $540^{\circ} \mathrm{C}$ has increased to about 5.2 a/o near the end of December.

\footnotetext{
* Hitherto referred to as "fuel rods."
} 
Sixteen of the eighteen U-Pu-Zr fuel elements, were removed from the reactor in December and are awaiting transfer to Argonne, Illinois, for a postirradiation examination after a maximum burnup of $5.1 \mathrm{a} / \mathrm{o}$.

The fuel pins of the four elements remaining in the reactor are jacketed in V-20 w/o Ti tubing. Two of the elements contain U-Pu-Zr fuel and two U-Pu-Ti. Irradiation is proceeding at maximum jacket temperatures of $540^{\circ} \mathrm{C}$.

Neutron radiographs through $\mathrm{V}-20 \mathrm{w} / \mathrm{O} \mathrm{Ti}$ jackets showed last month that two Th-20 w/o U fuel pins irradiated at 560 and $590^{\circ} \mathrm{C}$ maximum jacket temperature in CP -5 to $11.9 \mathrm{a} / 0 \mathrm{U}$ burnup had not elongated, but that $\mathrm{Th}-10 \mathrm{w} / \mathrm{o} \mathrm{Pu}-10 \mathrm{w} / \mathrm{o} \mathrm{U}$ pins irradiated, with jackets at $590^{\circ} \mathrm{C}$, to $13.3 \mathrm{a} / \mathrm{o}$ burnup and Th- $10 \mathrm{w} / \mathrm{O} \mathrm{Pu}-20 \mathrm{w} / \mathrm{O} \mathrm{U}$ pins irradiated, with jackets at $560^{\circ} \mathrm{C}$, to $7.8 \mathrm{a} / \mathrm{o}$ burnup had elongated an average of $8 \%$. The burnups of the Th-U pins have now increased to $13.6 \mathrm{a} / \mathrm{o}$, and the burnups of the two sets of $\mathrm{Th}-\mathrm{Pu}-\mathrm{U}$ pins have now increased to $15.8 \mathrm{a} / \mathrm{O}(\mathrm{U}+\mathrm{Pu})$ and $9.2 \mathrm{a} / \mathrm{o}$ $(U+P u)$, respectively.

Table VIII summarizes design details and irradiation variables for all current experiments with metal fuels as well as for the specimens recently removed from the reactor.

TABLE VIII. Status of Metal Fuel Irradiations in Progress--Fast Reactor Development

\begin{tabular}{|c|c|c|c|c|c|c|c|c|c|c|c|}
\hline \multirow{3}{*}{$\begin{array}{c}\text { Test } \\
\text { Reactor }\end{array}$} & \multirow[b]{3}{*}{$\begin{array}{l}\text { Capsule } \\
\text { or S/A No. }\end{array}$} & \multirow[b]{3}{*}{$\begin{array}{l}\text { Specimen } \\
\text { Number }\end{array}$} & \multicolumn{5}{|c|}{ Design Parameters } & \multicolumn{4}{|c|}{ Operating Conditions } \\
\hline & & & \multirow{2}{*}{$\begin{array}{c}\text { Fuel } \\
\text { Composition } \\
(w / 0)\end{array}$} & \multirow{2}{*}{$\begin{array}{c}\text { Effective } \\
\text { Density } \\
(\%)\end{array}$} & \multirow{2}{*}{$\begin{array}{c}\cdot \\
\text { Cladding } \\
\text { Composition }\end{array}$} & \multirow[b]{2}{*}{$\begin{array}{l}\text { Cladding } \\
O D \text { (in.) }\end{array}$} & \multirow{2}{*}{$\begin{array}{c}\text { Cladding } \\
\text { Thickness } \\
\text { (in.) }\end{array}$} & \multirow[b]{2}{*}{$\begin{array}{l}\operatorname{Max} \\
k W / f t\end{array}$} & \multirow[b]{2}{*}{$\begin{array}{l}\text { Max Cladding } \\
\text { Temp }\left({ }^{\circ} \mathrm{C}\right)\end{array}$} & \multicolumn{2}{|c|}{ Burnup to Date. } \\
\hline & & & & & & & & & & $a / 0(U+P u)$ & $\mathrm{fiss} / \mathrm{cc} \times 10^{-20^{a}}$ \\
\hline $\begin{array}{l}\text { EBR-II } \\
\text { EBR-II }\end{array}$ & $\begin{array}{l}X 606 \\
X G 05\end{array}$ & $\begin{array}{l}\text { ND23 } \\
\text { ND24 }\end{array}$ & $\begin{array}{l}\mathrm{U}-15 \mathrm{PU}-10 \mathrm{Zr} \\
\mathrm{U}-15 \mathrm{Pu}-10 \mathrm{Zr}\end{array}$ & $\begin{array}{l}66 \\
66\end{array}$ & $\begin{array}{l}V-20 w / 0 \mathrm{Ti} \\
V-20 \mathrm{w} / 0 \mathrm{Ti}\end{array}$ & $\begin{array}{l}0.209 \\
0.209\end{array}$ & $\begin{array}{l}0.016 \\
0.016\end{array}$ & $\begin{array}{l}9.1 \\
9.1\end{array}$ & $\begin{array}{l}540 \\
535\end{array}$ & $\begin{array}{l}5.0 \\
4.8\end{array}$ & $\begin{array}{l}12.1 \\
11.6\end{array}$ \\
\hline $\begin{array}{l}E B R-11 \\
E B R-11 \\
E B R-11 \\
E B R-11\end{array}$ & $\begin{array}{l}\text { XA07 } \\
\text { XA07 } \\
\text { XA07 } \\
\text { XA07 }\end{array}$ & $\begin{array}{l}\text { ND28 } \\
\text { ND41 } \\
\text { ND32 } \\
\text { ND43 }\end{array}$ & $\begin{array}{l}\mathrm{U}-15 \mathrm{PU}-9 \mathrm{Zr} \\
\mathrm{U}-15 \mathrm{PU}-9 \mathrm{Zr} \\
\mathrm{U}-15 \mathrm{PU}-9 \mathrm{Zr} \\
\mathrm{U}-15 \mathrm{PU}-9 \mathrm{Zr}\end{array}$ & $\begin{array}{l}75 \\
75 \\
75 \\
75\end{array}$ & $\begin{array}{l}304 \text { SS } \\
304 \text { SS } \\
316 \text { SS } \\
\text { Hastelloy-X }\end{array}$ & $\begin{array}{l}0.208 \\
0.208 \\
0.196 \\
0.196\end{array}$ & $\begin{array}{l}0.021 \\
0.021 \\
0.015 \\
0.015\end{array}$ & $\begin{array}{l}9.5 \\
9.5 \\
9.5 \\
9.5\end{array}$ & $\begin{array}{l}630 \\
625 \\
605 \\
615\end{array}$ & $\begin{array}{l}5.1 \\
4.9 \\
4.7 \\
4.9\end{array}$ & $\begin{array}{l}14.2 \\
13.9 \\
13.3 \\
13.7\end{array}$ \\
\hline $\begin{array}{l}E B R-\| \\
E B R-\| \\
E B R-\| \\
E B R-\| \\
E B R-\| \\
E B R-\| \\
E B R-\| \\
E B R-\| \\
E B R-\| \\
E B R-\| \\
E B R-\| \\
E B R-\|\end{array}$ & $\begin{array}{l}\text { XA07 } \\
\text { XA07 } \\
\text { XA07 } \\
\text { XA07 } \\
\text { XA07 } \\
\text { XA07 } \\
\text { XA07 } \\
\text { XA07 } \\
\text { XA07 } \\
\text { XA07 } \\
\text { XA07 } \\
\text { XA07 }\end{array}$ & $\begin{array}{l}\text { ND25 } \\
\text { ND27 } \\
\text { ND26 } \\
\text { ND29 } \\
\text { ND30 } \\
\text { ND31 } \\
\text { ND33 } \\
\text { ND34 } \\
\text { ND35 } \\
\text { ND37 } \\
\text { ND39 } \\
\text { ND44 }\end{array}$ & $\begin{array}{l}\text { U-14 Pu-12 Zr } \\
\text { U-14 Pu-12 Zr } \\
\text { U-14 Pu-12 Zr } \\
\text { U-14 Pu-12 Zr } \\
\text { U-14 Pu-12 Zr } \\
\text { U-14 Pu-12 Zr } \\
\text { U-14 Pu-12 Zr } \\
\text { U-14 Pu-12 Zr } \\
\text { U-14 Pu-12 Zr } \\
\text { U-14 Pu-12 Zr } \\
\text { U-14 Pu-12 Zr } \\
\text { U-14 Pu-12 Zr }\end{array}$ & $\begin{array}{l}76 \\
76 \\
76 \\
76 \\
76 \\
76 \\
76 \\
76 \\
76 \\
66 \\
66 \\
66\end{array}$ & $\begin{array}{l}304 \text { SS } \\
304 \text { SS } \\
316 \text { SS } \\
316 \text { SS } \\
316 \text { SS } \\
316 \text { SS } \\
\text { Hastelloy-X } \\
\text { Hastelloy-X } \\
\text { Hastelloy-X } \\
\text { Hastelloy-X-280 } \\
\text { Hastelloy-X-280 } \\
\text { Hastelloy-X-280 }\end{array}$ & $\begin{array}{l}0.208 \\
0.208 \\
0.196 \\
0.196 \\
0.196 \\
0.196 \\
0.196 \\
0.196 \\
0.196 \\
0.208 \\
0.208 \\
0.208\end{array}$ & $\begin{array}{l}0.021 \\
0.021 \\
0.015 \\
0.015 \\
0.015 \\
0.015 \\
0.015 \\
0.015 \\
0.015 \\
0.015 \\
0.015 \\
0.015\end{array}$ & $\begin{array}{l}9.1 \\
9.1 \\
8.6 \\
8.6 \\
9.1 \\
9.1 \\
9.1 \\
9.1 \\
9.1 \\
8.6 \\
8.6 \\
8.6\end{array}$ & $\begin{array}{l}600 \\
605 \\
590 \\
595 \\
615 \\
610 \\
605 \\
610 \\
615 \\
610 \\
610 \\
600\end{array}$ & $\begin{array}{l}4.4 \\
4.5 \\
4.3 \\
4.4 \\
4.9 \\
4.7 \\
4.6 \\
4.7 \\
4.9 \\
4.9 \\
4.8 \\
4.7\end{array}$ & $\begin{array}{l}11.5 \\
11.7 \\
11.1 \\
11.6 \\
12.7 \\
12.3 \\
.12 .0 \\
12.2 \\
12.7 \\
12.2 \\
12.1 \\
11.7\end{array}$ \\
\hline $\begin{array}{l}\text { EBR-II } \\
\text { EBR-II }\end{array}$ & $\begin{array}{l}X 605 \\
X G 06\end{array}$ & $\begin{array}{l}\mathrm{NCl7} \\
\mathrm{NC} 23\end{array}$ & $\begin{array}{l}\mathrm{U}-15 \mathrm{Pu}-10 \mathrm{Ti} \\
\mathrm{U}-15 \mathrm{Pu}-10 \mathrm{Ti}\end{array}$ & $\begin{array}{l}63 \\
63\end{array}$ & $\begin{array}{l}V-20 \mathrm{w} / 0 \mathrm{Ti} \\
V-20 \mathrm{w} / 0 \mathrm{Ti}\end{array}$ & $\begin{array}{l}0.209 \\
0.209\end{array}$ & $\begin{array}{l}0.016 \\
0.016\end{array}$ & $\begin{array}{l}9.1 \\
9.1\end{array}$ & $\begin{array}{l}540 \\
540\end{array}$ & $\begin{array}{l}4.9 \\
5.2\end{array}$ & $\begin{array}{l}10.9 \\
11.5\end{array}$ \\
\hline $\begin{array}{l}C P-5 \\
C P-5\end{array}$ & $\begin{array}{l}\text { CP-50 } \\
C P-50\end{array}$ & $\begin{array}{l}1 \mathrm{~N} 16 \\
4 \mathrm{~N} 19\end{array}$ & $\begin{array}{l}\text { Th-20 U } \\
\text { Th-20 U }\end{array}$ & $\begin{array}{l}75 \\
75\end{array}$ & $\begin{array}{l}V-20 \mathrm{w} / 0 \mathrm{Ti} \\
V-20 \mathrm{w} / 0 \mathrm{Ti}\end{array}$ & $\begin{array}{l}0.196 \\
0.196\end{array}$ & $\begin{array}{l}0.015 \\
0.015\end{array}$ & $\begin{array}{l}8.7 \\
8.7\end{array}$ & $\begin{array}{l}590 \\
560\end{array}$ & $\begin{array}{l}13.6 \\
13.6\end{array}$ & $\begin{array}{l}6.5 \\
6.5\end{array}$ \\
\hline $\begin{array}{l}C P-5 \\
C P-5\end{array}$ & $\begin{array}{l}C P-50 \\
C P-50\end{array}$ & $\begin{array}{r}2 \mathrm{~N} 17 \\
.5 \mathrm{~N} 20\end{array}$ & $\begin{array}{l}\text { Th-10 Pu-10 U } \\
\text { Th-10 Pu-10 U }\end{array}$ & $\begin{array}{l}75 \\
75\end{array}$ & $\begin{array}{l}V-20 \mathrm{w} / 0 \mathrm{Tj} \\
V-20 \mathrm{w} / 0 \mathrm{Ti}\end{array}$ & $\begin{array}{l}0.196 \\
0.196\end{array}$ & $\begin{array}{l}0.015 \\
0.015\end{array}$ & $\begin{array}{l}9.2 \\
9.2\end{array}$ & $\begin{array}{l}590 \\
590\end{array}$ & $\begin{array}{l}15.8 \\
15.8\end{array}$ & $\begin{array}{r}7.4 \\
. \quad 7.4\end{array}$ \\
\hline $\begin{array}{l}C P-5 \\
C P-5\end{array}$ & $\begin{array}{l}C P-50 \\
C P-50\end{array}$ & $\begin{array}{l}3 \mathrm{~N} 18 \\
6 \mathrm{~N} 21\end{array}$ & $\begin{array}{l}\text { Th-10 Pu-20 U } \\
\text { Th-10 Pu-20 U }\end{array}$ & $\begin{array}{l}75 \\
75\end{array}$ & $\begin{array}{l}V-20 \mathrm{w} / 0 \mathrm{Ti} \\
V-20 \mathrm{w} / 0 \mathrm{Ti}\end{array}$ & $\begin{array}{l}0.196 \\
0.196\end{array}$ & $\begin{array}{l}0.015 \\
0.015\end{array}$ & $\begin{array}{l}8.7 \\
8.7\end{array}$ & $\begin{array}{l}560 \\
560\end{array}$ & $\begin{array}{l}9.2 \\
9.2\end{array}$ & $\begin{array}{l}6.7 \\
6.7\end{array}$ \\
\hline
\end{tabular}

aased on effective density.

The U-Pu-Zr and U-Pu-Ti specimens that were recently removed from CP-5 and that were reported (see Progress Report for October 1966, ANL-7267, p. 35) as having calculated burnups of 10.2 and $9.0 \mathrm{a} / \mathrm{o}$, 
respectively, have been subjected to radiochemical analyses to determine the actual burnup. The U-Pu-Zr specimen had reached a burnup of $12.5 \mathrm{a} / 0$; the U-Pu-Ti specimen achieved a burnup of $10.7 \mathrm{a} / 0$.

Postirradiation metallographic examinations of the two specimens are being conducted. Transverse as well as longitudinal sections on these rods showed the fuel to be in excellent condition. The specimens were irradiated in V-20 w/o Ti tubing at maximum jacket temperatures of $640^{\circ} \mathrm{C}$. There is no evidence of interaction of the fuels with this cladding material.

Microscopic examination of the U-Pu-Zr alloy shows interconnected fission gas bubbles, which apparently form a continuous path to the surface of the fuel. The supposition is supported by the large volume of fission gas that was recovered from the plenum above the fuel element. Although the U-Pu-Zr alloy showed radial cracks, there was no evidence of cracks in the U-Pu-Ti alloy. Also, the pore distribution was much finer in the U-Pu-Ti alloy than in the U-Pu-Zralloy. The transverse sections of both fuel elements showed distinct bands that could be correlated to the transformation temperatures of the respective alloy phase.

Utilization of the volume of the gas released in the U-Pu- $\mathrm{Zr}$ element and that of the plenum, as determined by the actual sodium level in the specimen, made it possible to calculate an operating internal pressure of $\sim 2200$ psi, considerably lower than that calculated to produce jacket failure. It is apparent that the element was capable of attaining burnup higher than $12.5 \mathrm{a} / \mathrm{o}$.

\section{Oxide and Carbide Fuels}

a. Irradiations of Ceramic and Cermet Fuels in EBR-II. In November, four elements fueled with UC-20 w/o PuC were charged into EBR-II to yield performance information at linear heat ratings of 16 to $25 \mathrm{~kW} / \mathrm{ft}$ and a nominal burnup originally planned to be $5 \mathrm{a} / \mathrm{o}$, but now scheduled for $6 \mathrm{a} / \mathrm{o}$ burnup, while similar rods, intended for burnup to $10 \mathrm{a} / \mathrm{o}$, had achieved burnups of 2.7 to $3.9 \mathrm{a} / \mathrm{o}$. Three similar fuel elements, intended for $5 \mathrm{a} / \mathrm{o}$ burnup had attained burnup levels of 4.5 to $4.6 \mathrm{a} / \mathrm{o}$. The jacket materials for the se fuel elements include Type 304 stainless steel, Hastelloy-X, and $\mathrm{Nb}-1 \mathrm{w} / \mathrm{O} \mathrm{Zr}$.

The elements intended for $6 \mathrm{a} / \mathrm{o}$ and $10 \mathrm{a} / \mathrm{o}$ burnup have now attained burnups of 0.50 to $0.80 \mathrm{a} / \mathrm{o}$ and of 3.0 to $4.3 \mathrm{a} / \mathrm{o}$, respectively. Two are jacketed with $\mathrm{Nb}-1 \mathrm{w} / \mathrm{o} \mathrm{Zr}$, one with Hastelloy-X, and one with $\mathrm{V}-20 \mathrm{w} / \mathrm{o} \mathrm{Ti}$. Discharge of the other three, which were intended for $5 \mathrm{a} / \mathrm{o}$ burnup, is imminent, as their present burnup levels are now 4.8 to $5.0 \mathrm{a} / \mathrm{o}$. 
Nine fuel elements containing $\mathrm{UO}_{2}-20 \mathrm{w} / \mathrm{o} \mathrm{PuO}_{2}$, also under irradiation in November and still in EBR-II, are as follows: one in V-20 w/o Ti at $575^{\circ} \mathrm{C}$, burnup now $3.0 \mathrm{a} / \mathrm{o}$; five in Type 304 stainless steel at 555 to $630^{\circ} \mathrm{C}$, burnup now 3.0 to $3.1 \mathrm{a} / \mathrm{o}$; three in Hastelloy-X at 590 to $615^{\circ} \mathrm{C}$, burnup now 2.9 to $3.1 \mathrm{a} / \mathrm{o}$. The mixed oxides are scheduled for discharge at $5 \mathrm{a} / \mathrm{o}$ burnup.

The burnup levels for the stainless steel-jacketed cermets SS $-40 \mathrm{w} / 0 \mathrm{PuO}_{2}, \mathrm{SS}-27 \mathrm{w} / \mathrm{o} \mathrm{PuO}_{2}$, and SS- $27 \mathrm{w} / \mathrm{o} \mathrm{UO}_{2}$ have increased during the month as follows: from $3.6 \mathrm{a} / \mathrm{o}$ in November to a current $4.2 \mathrm{a} / \mathrm{o}$ for the plutonia cermets, and from $2.8 \mathrm{a} / 0$ to $3.2 \mathrm{a} / \mathrm{o}$ for the urania cermets. The discharge level scheduled for the cermets is 7 a/o burnup.

Tables IX, $X$, and XI list the mixed oxide, mixed carbide, and stainless steel- $\mathrm{PuO}_{2}$ or $-\mathrm{UO}_{2}$ cermet fuel elements undergoing irradiation in $\mathrm{EBR}-\mathrm{II}$.

Three UC-20w/o PuC elements, two with Type 316 stainless steel jackets and one with a vanadium jacket, and two $\mathrm{UO}_{2}-20 \mathrm{w} / \mathrm{o} \mathrm{PuO}_{2}$ elements with Type 304 stainless steel jackets, all at burnup levels between 2 and 3 a/o, have been removed from the reactor for shipment to the Metallurgy alpha-gamma hot cell.

TABLE IX. Status of Irradiations of UC-20 w/o PUC Fuel in EBR-II

\begin{tabular}{|c|c|c|c|c|c|c|c|c|c|}
\hline \multirow{3}{*}{$\begin{array}{c}\text { Capsule } \\
\text { or S/A No. }\end{array}$} & \multirow[b]{3}{*}{$\begin{array}{l}\text { Specimen } \\
\text { Number }\end{array}$} & \multicolumn{4}{|c|}{ Design Parameters } & \multicolumn{4}{|c|}{ Operating Conditions } \\
\hline & & \multirow{2}{*}{$\begin{array}{c}\text { Effective } \\
\text { Density } \\
(\%)\end{array}$} & \multirow{2}{*}{$\begin{array}{c}\text { Cladding } \\
\text { Composition }\end{array}$} & \multirow[b]{2}{*}{$\begin{array}{l}\text { Cladding } \\
O D \text { (in.) }\end{array}$} & \multirow{2}{*}{$\begin{array}{l}\text { Cladding } \\
\text { Thickness } \\
\text { (in.) }\end{array}$} & \multirow[b]{2}{*}{$\begin{array}{l}\text { Max } \\
\text { kW/ft }\end{array}$} & \multirow{2}{*}{$\begin{array}{c}\text { Max Cladding } \\
\text { Temp }\left(^{\circ} \mathrm{C}\right)\end{array}$} & \multicolumn{2}{|c|}{ Burnup to Date } \\
\hline & & & & & & & & $a / o(U+P u)$ & fiss $/ \mathrm{cc} \times 10^{-20(a)}$ \\
\hline XGO5 & SMV-2 & 84 & 304 SS & 0.297 & 0.020 & 19.4 & 645 & 4.8 & 13.4 \\
\hline$X G 05$ & HMV -5 & 80 & Hastelloy-X & 0.297 & 0.015 & 22.0 & 670 & 4.0 & 13.1 \\
\hline XG05. & NMV-11 & 84 & $\mathrm{Nb}-1 \mathrm{w} / \mathrm{Z} \mathrm{Zr}$ & 0.281 & 0.012 & 20.0 & 645 & 5.0 & 14.0 \\
\hline$x 008$ & NMP-2 & 82 & $\mathrm{Nb}-1 \mathrm{w} / 0 \mathrm{Zr}$ & 0.281 & 0.012 & 16.7 & 545 & 3.0 & 8.1 \\
\hline$\times 008$ & NMV-4 & 80 & $\mathrm{Nb}-1 \mathrm{w} / 0 \mathrm{Zr}$ & 0.281 & 0.012 & 25.0 & 635 & 4.3 & 11.4 \\
\hline X008 & NMV-7 & 80 & $\mathrm{Nb}-1 \mathrm{w} / 0 \mathrm{Zr}$ & 0.281 & 0.012 & 22.2 & 605 & 3.9 & 10.4 \\
\hline $\mathrm{X008}$ & NMV-1? & 86 & $\mathrm{Nb}-1 \mathrm{w} / 0 \mathrm{Zr}$ & 0.281 & 0.012 & 24.9 & 635 & 4.3 & 12.1 \\
\hline$\times 008$ & HMV-1 & 80 & Hastelloy-X & 0.297 & 0.015 & 22.7 & 640 & 3.8 & 10.2 \\
\hline$X 008$ & HMV-4 & 80 & Hastelloy-X & 0.297 & 0.015 & 25.0 & 670 & 4.2 & 11.2 \\
\hline$\times 008$ & HWMP-1 & 82 & Hastelloy $-X+W$ & 0.297 & 0.020 & 16.1 & 555 & 2.9 & 7.8 \\
\hline X008 & HWMV-1 & 83 & Hastelloy $-X+W$ & 0.297 & 0.020 & 24.6 & 685 & 4.3 & 11.7 \\
\hline$x 015$ & NMP-1 & 80 & $\mathrm{Nb}-1 \mathrm{w} / \mathrm{Zr}$ & 0.281 & 0.012 & 15.8 & 535 & 0.50 & 1.3 \\
\hline X015 & NMV-3 & 80 & $\mathrm{Nb}-1 \mathrm{w} / \mathrm{O} \mathrm{Zr}$ & 0.281 & 0.012 & 24.3 & 625 & 0.74 & 2.0 \\
\hline X015 & HMV-2 & 79 & Hastelloy-X & 0.297 & 0.015 & 16.6 & 670 & 0.81 & 2.1 \\
\hline$\times 015$ & TVMV-1 & 82 & $\mathrm{~V}-20 \mathrm{w} / 0 \mathrm{Ti}$ & 0.297 & 0.020 & 21.4 & 620 & 0.65 & 1.8 \\
\hline
\end{tabular}

aBased on effective density.

TABLE X. Status of Irradiations of $\mathrm{UO}_{2}-20$ w/o $\mathrm{PuO}_{2}$ Fuel in Capsule XOll in EBR-1l

\begin{tabular}{|c|c|c|c|c|c|c|c|c|}
\hline \multirow[b]{3}{*}{$\begin{array}{l}\text { Specimen } \\
\text { Number }\end{array}$} & \multicolumn{4}{|c|}{ Design Parameters } & \multicolumn{4}{|c|}{ Operating Conditions } \\
\hline & \multirow{2}{*}{$\begin{array}{c}\text { Effective } \\
\text { Density } \\
(\%)\end{array}$} & \multirow[b]{2}{*}{$\begin{array}{l}\text { Cladding } \\
\text { Composition }\end{array}$} & \multirow[b]{2}{*}{$\begin{array}{l}\text { Cladding } \\
\text { OD (in.) }\end{array}$} & \multirow{2}{*}{$\begin{array}{l}\text { Cladding } \\
\text { Thickness } \\
\text { (in.) }\end{array}$} & \multirow[b]{2}{*}{$\begin{array}{l}\text { Max } \\
\mathrm{kW} / \mathrm{ft}\end{array}$} & \multirow{2}{*}{$\begin{array}{l}\text { Max Cladding ' } \\
\text { Temp }(\mathrm{OC})\end{array}$} & \multicolumn{2}{|c|}{ Burnup to Date } \\
\hline & & & & & & & $a / 0(U+P u)$ & fiss/cc $\times 10^{-20^{a}}$ \\
\hline SOV-3 & 83 & 304 SS & 0.296 & 0.019 & 21.7 & 610 & 3.1 & 6.4 \\
\hline HOV-4 & 80 & Hastelloy-X & 0.295 & 0.014 & 22.5 & 600 & 3.1 & 6.0 \\
\hline TVOV-1 & 77 & $\mathrm{~V}-20 \cdot \mathrm{w} / 0 \mathrm{Ti}$ & 0.297 & 0.020 & 20.8 & .575 & 3.0 & .5 .7 \\
\hline SOV-7 & 85 & 304 SS & 0.296 & 0.019 & 23.4 & 630 & 3.0 & 6.3 \\
\hline SOV-1 & 80 & 304 SS & 0.296 & 0.019 & 19.9 & 590 & 3.0 & 5.9 \\
\hline HOV-10 & 86 & Hastelloy-X & .0 .295 & 0.014 & 23.7 & 615 & 2.9 & 6.2 \\
\hline HOV-15 & 80 & Hastelloy-X & 0.295 & 0.014 & 21.1 & 590 & 2.9 & 5.8 \\
\hline
\end{tabular}

a Based on effective density. 
TABLE XI. Status of Type 304 Stainless Steel-clad Cermet Fuel Irradiations in Capsule X011 in EBR-II

\begin{tabular}{|c|c|c|c|c|c|c|c|c|}
\hline \multirow[b]{3}{*}{$\begin{array}{l}\text { Specimen } \\
\text { Number }\end{array}$} & \multicolumn{4}{|c|}{ Design Parameters } & \multicolumn{4}{|c|}{ Operating Conditions } \\
\hline & \multirow{2}{*}{$\begin{array}{l}\text { Fuel } \\
\text { Composition } \\
\text { (w/o) }\end{array}$} & \multirow{2}{*}{$\begin{array}{c}\text { Effective } \\
\text { Density } \\
\left\langle\psi_{0}\right\rangle\end{array}$} & \multirow[b]{2}{*}{$\begin{array}{l}\text { Cladding } \\
\text { OD (in.) }\end{array}$} & \multirow{2}{*}{$\begin{array}{c}\text { Cladding } \\
\text { Thickness } \\
\text { (in.) }\end{array}$} & \multirow[b]{2}{*}{$\begin{array}{l}\text { Max } \\
\text { kWift }\end{array}$} & \multirow[b]{2}{*}{$\begin{array}{l}\text { Max Cladding } \\
\text { Temp }\left({ }^{\circ} \mathrm{C}\right)\end{array}$} & \multicolumn{2}{|c|}{ Burnup to Date } \\
\hline & & & & & & & $a / 0(U+P u)$ & fiss/cc $\times 10^{-20^{2}}$ \\
\hline $5 P-9$ & $\mathrm{SS}-40 \mathrm{PuO}_{2}$ & 98 & 0.301 & 0.015 & 10.8 & 495 & 4.2 & 3.2 \\
\hline $5 P-12$ & $\mathrm{SS}-27 \mathrm{PuO}_{2}$ & 99 & 0.294 & 0.015 & 7.1 & 450 & 4.2 & 2.1 \\
\hline $5 U-14$ & $\mathrm{SS}-27 \mathrm{UO}_{2}$ & 98 & 0.298 & 0.013 & 5.6 & 435 & 3.2 & 1.6 \\
\hline
\end{tabular}

aased on effective density,

b. Fluidized-bed Process for Preparation of (U, Pu)C. A series of twelve runs has been conducted to demonstrate the preparation of highpurity $(\mathrm{U}-15 \mathrm{w} / \mathrm{O} \mathrm{Pu}) \mathrm{C}$ by the fluidized-bed technique (see Progress Reports for June, July, and October 1966, ANL-7230, p. 45; ANL-7245, p. 10; and ANL-7267, p. 41). In each run, $300 \mathrm{~g}$ of uranium-plutonium alloy (3/8-in:dia rods) were hydrided at $250^{\circ} \mathrm{C}$ to form a powder; this, in turn, was fluidized and reacted at 550 to $800^{\circ} \mathrm{C}$ with methane-hydrogen gas mixtures to form the monocarbide. These runs were carried out using once-through fluidizing gas flow, in a $1 \frac{5}{8}$-in.-ID reactor which could be manipulated (e.g., for product removal) in a high-purity helium-atmosphere glovebox. This reactor is capable of producing $600-\mathrm{g}$ batches but the batch size was limited to conserve material. The run conditions and product analyses are shown in Table XII.

TABLE XII. Preparation of (U-15 w/o Pu)C in a Fluidized-bed Reactor (300-g scale; 3/8-in.-dia alloy rods hydrided at $250^{\circ} \mathrm{C}$ prior to carbiding)

\begin{tabular}{|c|c|c|c|c|c|c|c|c|c|c|c|}
\hline \multirow{3}{*}{$\begin{array}{l}\text { Run } \\
\text { No. }\end{array}$} & \multicolumn{5}{|c|}{ Carbiding Conditions } & \multicolumn{4}{|c|}{ Product Analysis (w/o) } & \multirow{2}{*}{\multicolumn{2}{|c|}{$X$-ray Analysis ${ }^{C}$}} \\
\hline & \multirow{2}{*}{$\begin{array}{c}\text { Temperature } \\
\left({ }^{\circ} \mathrm{C}\right)\end{array}$} & \multirow{2}{*}{$\begin{array}{c}\text { Pressure } \\
\text { (atm) }\end{array}$} & \multirow{2}{*}{$\begin{array}{c}\mathrm{CH}_{4} \mathrm{Conc}^{\mathrm{a}} \\
(\mathrm{v} / \mathrm{O})\end{array}$} & \multirow{2}{*}{$\begin{array}{l}\text { Carbiding } \\
\text { Time (hr) }\end{array}$} & \multirow{2}{*}{$\begin{array}{c}\text { Final } \mathrm{H}_{2} \\
\text { Treatment (hr) }\end{array}$} & \multirow[b]{2}{*}{ Carbon } & \multirow[b]{2}{*}{ Oxygen } & \multirow[b]{2}{*}{ Nitrogen } & \multirow{2}{*}{$\begin{array}{c}\text { Equivalent } \\
\text { Carbon }\end{array}$} & & \\
\hline & & & & & & & & & & Major & Minor \\
\hline 1 & 750 & 4 & $10^{d}$ & 6 & 0 & 4.11 & 0.04 & $-f$ & 4.16 & MC & $\mathrm{BMH}_{3}$ \\
\hline 2 & 750 & 4 & $10^{\mathrm{d}}$ & 12 & 0 & 4.96 & $\begin{array}{l}0.016 \\
0.084^{e}\end{array}$ & $-f$ & 4.99 & MC & none \\
\hline 3 & $550-750$ & 4 & 10 & 11.6 & 0 & 4.89 & 0.049 & $-f$ & 4.95 & $M C$ & none \\
\hline 4 & 750 & 4 & $10^{d}$ & 11.8 & 0 & 4.92 & $\begin{array}{l}0.077 \\
0.12^{\mathrm{e}}\end{array}$ & $-f$ & 5.00 & $M C$ & $\mathrm{M}_{2} \mathrm{C}_{3}$ \\
\hline 5 & 800 & 4 & 10 & 10.3 & 2 & 4.78 & $\begin{array}{l}0.073 \\
0.35^{\mathrm{e}}\end{array}$ & $-f$ & 4.85 & $M C$ & none \\
\hline 6 & 800 & $\left.\begin{array}{l}1.33 \\
4\end{array}\right\}$ & 10 & 10.5 & 2 & 4.89 & 0.18 & $-f$ & 5.05 & $M C$ & $\mathrm{M}_{2} \mathrm{C}_{3}$ \\
\hline 7 & 800 & 4 & 10 & 6.8 & 1.5 & 4.80 & 0.058 & $-f$ & 4.86 & MC & none \\
\hline 8 & 800 & 2 & 8 & 6.8 & 0.5 & 4.92 & 0.057 & $-f$ & 4.98 & none & none \\
\hline 9 & 800 & 4 & -9 & 11.4 & 2.5 & 4.76 & 0.02 & 0.008 & 4.79 & none & none \\
\hline 10 & 800 & 2 & 8 & 7.9 & 5.5 & 4.83 & 0.086 & 0.013 & 4.90 & none & none \\
\hline 11 & 800 & 2 & 8 & 7.0 & 0.6 & 4.64 & 0.12 & 0.016 & 4.74 & none & none \\
\hline 12 & 800 & 2 & 8 & 14.3 & 6.0 & 4.70 & 0.036 & 0.017 & 4.74 & none & none \\
\hline
\end{tabular}

a Balance hydrogen.

boxygen and nitrogen are soluble in $(U, \mathrm{Pu}) \mathrm{C}$ and replace carbon in the lattice; therefore, the equivalent carbon concentration in weight percent, $\mathrm{C}_{\mathrm{eq}}=\mathrm{w} / 0 \mathrm{C}+(12 / 16) \mathrm{w} / 0 \mathrm{O}+(12 / 14) w / 0 \mathrm{~N}$.

$C_{M}=(U-15$ w/o Pu).

$\mathrm{d}_{\text {Near }}$ the end of the run, $\mathrm{CH}_{4}$ concentration was decreased to $2.5 \mathrm{v} / \mathrm{O}$.

The higher values were assumed to be due to sample contamination. These higher values were not used in the equivalent carbon calculation.

f Spurious results; a value of 0.02 was assumed for calculating the equivalent carbon concentration.

gVariable as follows: 0 to $0.8 \mathrm{hr}, 1.0 \mathrm{w} / 0 ; 0.8$ to $3.8 \mathrm{hr}, 2.6 \mathrm{v} / 0 ; 3.8$ to $6.5 \mathrm{hr}, 5 \mathrm{v} / 0 ; 6.5 \mathrm{hr}$ to end of carbiding, $10.0 \mathrm{v} / 0$.

In these runs the control of the carbon content and purity of the product were emphasized. Uranium-plutonium monocarbide that is stoichiometric or slightly hyperstoichiometric with respect to carbon is the preferred carbide fuel for fast reactors because (i) it is more compatible with cladding materials and has lower fission gas release during irradiation than carbide fuels with lower carbon-to-metal atom ratios, and (ii) it has higher thermal conductivity than fuels containing a large excess of carbon. 
The methods for controlling the carbon content of the product in this series of runs were: (i) adjusting the methane concentration in the methanehydrogen fluidizing gas to prevent formation of free carbon; (ii) stopping the reaction after the appropriate extent of carburization had been reached; and (iii) treating with hydrogen at the end of the carburization period to remove excess carbon.

The methane concentrations of the inlet and outlet gas streams were determined by infrared analysis. The rate of carburization was determined from the difference between the inlet and outlet methane concentrations, and from the gas flow rate. The extent of carbiding during the course of the run was established with an accuracy of \pm 5 to $10 \%$ by integrating the rate of carburization with respect to time. However, chemical analysis of the product yielded a more accurate value $( \pm 1 \%)$ for the final extent of carbiding, and the values obtained during the run were adjusted accordingly. It was thus possible to plot the extent of carbiding versus time and to determine the effect of various changes in the reaction conditions on the rate of carbiding.

In one of the early experiments, run 3, it was found that the rate of carbiding was increased by raising the temperature from 550 to $750^{\circ} \mathrm{C}$ (see ANL-7230, p. 45). Consequently, beginning with run 5, the temperature was maintained at $800^{\circ} \mathrm{C}$, the upper operating temperature for this reactor.

The effect of methane concentration on the rate of reaction was investigated in run 9 . The reaction rates at 1.0 and $2.5 \mathrm{v} / 0$ methane during the initial portion of run 9 were much lower than the rates at 5 and $10 \mathrm{v} / 0$ methane during later portions of the run. The effect of an increase in pressure, observed by comparing the carbiding rates for runs made at 2 atm with those made at 4 atm pressure, was a slight increase in reaction rate. The effect of the pressure change observed in run 6 is a special case that is discussed below.

In runs 2 through 9, carbiding was interrupted after a period of several hours to rehydride the residual metal in the particles and break up the carbide reaction layer which appeared to be inhibiting further carbiding (see ANL-7267, p. 41). After a carbon content of about 4.0 to $4.2 \mathrm{w} / \mathrm{o}$ was reached (stoichiometric monocarbide contains $4.80 \mathrm{w} / \mathrm{o}$ carbon), the rate of reaction decreased markedly. Lowering the temperature to $25-400^{\circ} \mathrm{C}$ at this point in runs 2 through 9 to rehydride the residual metal permitted the completion of monocarbide formation in a few hours. This effect can be seen in the data from run 7 in Fig. 7.

In all runs the methane concentration in the methane-hydrogen fluidizing gas was such that $(\mathrm{U}, \mathrm{Pu})_{2} \mathrm{C}_{3}$ would be expected to form if the reaction were carried to completion; however, except for run 6 (discussed below), free carbon would not be expected to form. Any carbon in excess 


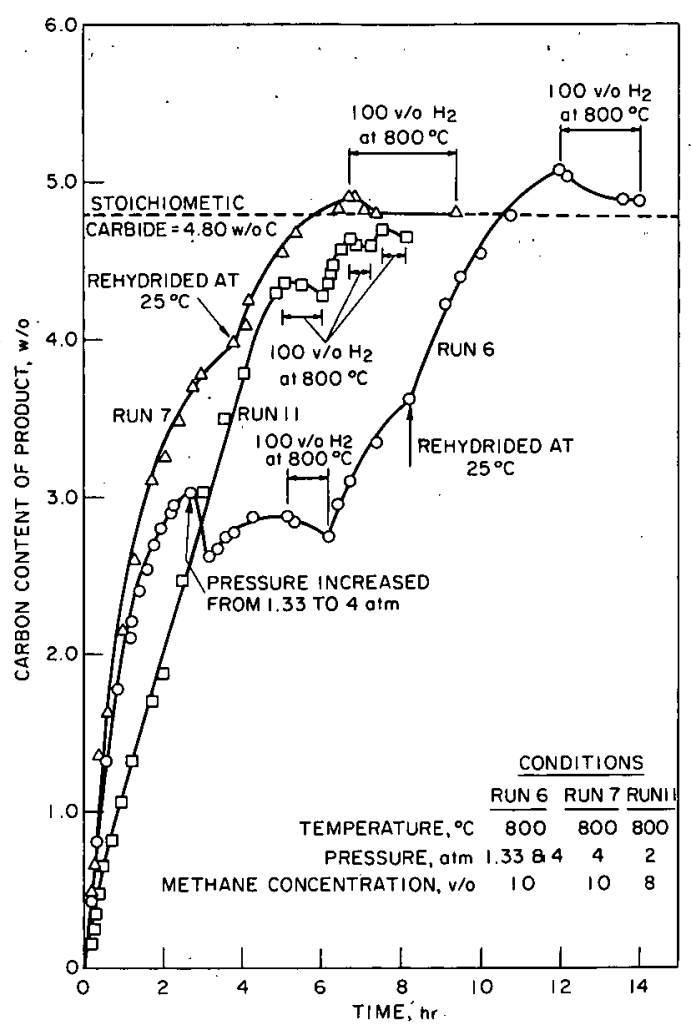

Fig. 7. Effects of Process Variables on the Preparation of $(\mathrm{U}, \mathrm{Pu}) \mathrm{C}$ in a Fluidized Bed of the stoichiometric carbon level $(4.80 \mathrm{w} / \mathrm{o})$ can be removed at the end of the carbiding period by reaction with hydrogen to form methane (see ANL-7267, p. 41). In run 11, it was found that a hydrogen treatment at the carbiding temperature prior to reaching the stoichiometric carbon concentration also resulted in the release of carbon in the form of methane, as shown in Fig. 7. This result suggests the presence of a sesquicarbide layer on the outside of the particle, an intermediate layer of monocarbide, and a core of unreacted alloy. (In actuality, the layers are not sharply defined since the particles are very irregular in shape and possess interconnected porosity.) The conversion of the sesquicarbide layer to the monocarbide apparently resulted in an increase in the rate of carbiding, but by a different mechanism than that which took place with the lowtemperature hydriding of run 7 .

\section{Another approach to increasing} the rate of carburization was to use a double hydriding cycle prior to carbiding; this was tried in run 5 . It is well known that repeated hydriding and dehydriding results in a finer particle size than that from a single cycle. A smaller particle reduces the length of the diffusion path for carbon and, therefore, might be expected to be beneficial. However, the desired result was not obtained by use of this technique; the reaction rate was lower for run 5 than for the other runs, which had only one hydriding cycle prior to carbiding. A particle-size analysis of the product from run 5 showed a substantial portion (14.2 w/o) of large particle agglomerates. These agglomerates were easily broken into fine particles. It appears, therefore, that very fine particles were formed during the two hydriding cycles but that agglomeration of the particles resulted in a lower carbiding rate than in runs in which a single hydriding cycle was used.

In two of the runs, no attempt was made to increase the rate of carbiding. In run 1 , in which the period of uninterrupted carbiding was only $6 \mathrm{hr}$, the product was only $85 \%$ converted to monocarbide. In run 12 , the $12.5 \mathrm{hr}$ required to reach the stoichiometric monocarbide carbon content (total carbiding time, $14.3 \mathrm{hr}$ ) was a longer time than that used in any of the other runs. Therefore, a hydrogen treatment during carbiding appears to be beneficial, but the best sequence of operation has not been established as yet. 
As noted above, the operating conditions during carbiding in all runs except run 6 were such that free carbon would not be expected to form. During the first $2 \frac{3}{4}$ hr of run 6 , the methane concentration in the methanehydrogen fluidizing gas was maintained at $10 \mathrm{v} / 0$ at a total pressure of $1.33 \mathrm{~atm}$, conditions which would cause deposition of free carbon by the reaction

$$
\mathrm{CH}_{4}(\mathrm{~g}) \rightleftarrows \mathrm{C}(\mathrm{s})+2 \mathrm{H}_{2}(\mathrm{~g})
$$

where the equilibrium constant $\mathrm{k}$ is $\mathrm{p}_{\mathrm{H}_{2}}^{2} / \mathrm{p}_{\mathrm{CH}_{4}}=21.3$ atm at $800^{\circ} \mathrm{C} . \mathrm{A}$ comparison of the rate of carbiding of run 6 with that of $r$ un 7 in Fig. 7 indicates the undesirable effect of carrying out the reaction under conditions that produce free carbon. After $2 \frac{3}{4} \mathrm{hr}$, the rate of carbiding in run 6 was considerably lower than that in run 7. Raising the pressure to $4 \mathrm{~atm}$ resulted in reaction of the excess carbon to form methane and, ultimately, in an increase in the reaction rate.

An analysis of the data on rates of reaction indicated that it is possible to prepare $100 \mathrm{~kg}$ of $(\mathrm{U}, \mathrm{Pu}) \mathrm{C}$ by this process in a period of 10 to $12 \mathrm{hr}$ if the carbiding is carried out at a pressure of $10 \mathrm{~atm}$ and a reactor of suitable size ( $8 \mathrm{in}$. in dia) is employed. This rate of production is sufficient to resynthesize fuel from three $1000-\mathrm{MW}(\mathrm{e})$ nuclear power reactors.

The oxygen impurity levels for these products have been low, as shown in Table XII; frequently the two analyses of the product averaged about $0.05 \mathrm{w} / \mathrm{o}$ or lower. The two individual oxygen analyses for $\mathrm{runs} 2$, 4 , and 5 varied markedly and, therefore, they are listed separately. (Only the lower oxygen values for these runs were used in determining the equivalent carbon contents of Table XII..) The increase in oxygen content above about $0.05 \mathrm{w} / \mathrm{o}$ is almost certainly caused by the introduction of oxygen during sampling prior to analysis. The very low oxygen levels of some runs approach the impurity levels of the alloy feed material, about 0.01 to $0.02 \mathrm{w} / 0$.

Difficulties were encountered in the earlier analyses of the products for nitrogen, and those reported previously for the first eight runs (ANL-7267, p. 41) are believed to be erroneously high. It is now believed that the actual nitrogen content of the first eight runs was similar to that of the last four runs (see Table XII).

The low impurity levels obtained in these runs indicate that the reactant gases, methane and hydrogen, introduce very small amounts of impurities, a conclusion that is in agreement with calculations based on the flow rates and the impurity contents of the gases.

The equivalent carbon contents of the last eight runs, in which a final hydrogen treatment was employed, ranged from 4.70 to $5.05 \mathrm{w} / \mathrm{o}$. It is anticipated that this range will be narrowed when process conditions are optimized. 
Sieve analyses of the carbide products showed an average particle size of about 40 to $60 \mu$. This relatively fine material is suitable for fabrication into pellets by pressing and sintering, with no intermediate. processing. Preliminary work on pressing and sintering of one batch of this material has shown that densities in excess of $90 \%$ of theoretical can easily be obtained (see Progress Reports for October and November 1966 , ANL-7267, p. 59, and ANL-7279, p. 27).

In summary, the following conclusions have been drawn from these studies on the preparation of $(U, P u) C$ by the fluidized-bed technique:

(i) The operating conditions of pressure, temperature, and methane concentration should be such that free carbon does not form on the particles.

(ii) The rate of carbiding increases with increasing pressure, methane concentration (within the above restriction), and temperature (at least up to $800^{\circ} \mathrm{C}$ ).

(iii) After a carbon content of about $4.2 \mathrm{w} / \mathrm{o}$ is reached, the rate of carbiding can be increased by treating the bed with pure hydrogen either at lower temperatures (below $400^{\circ} \mathrm{C}$ ) to cause rehydriding and, apparently, to break up the outer reaction layer, or at the carbiding temperature, to remove a higher carbide reaction layer.

(iv) A final hydrogen treatment is effective in removing any excess carbon from the surface of the carbide particles to yield the monocarbide.

(v) It has been demonstrated that a powdered product can be produced which contains less than 1000 ppm oxygen and less than 200 ppm nitrogen; this material is suitable directly for fabrication into pellets by pressing and sintering.

\section{Fuel Cladding and Structure}

a. Jacket Development. In the production of 0.290-in.-OD (0.015-

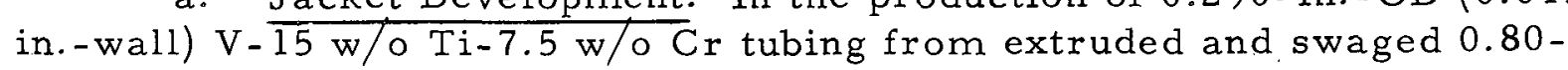
in.-OD (0.20-in.-wall) tube blanks, the application of tube-reducers was reported (see Progress Report for September 1966, ANL-7255, p. 29) to improve the uniformity of deformation, and to circumvent problems of lubrication and losses that occur on pointing tubing for drawing.

Although the development of this alloy represents an important advance over $\mathrm{V}-20 \mathrm{w} / \mathrm{O} \mathrm{Ti}$ for the jacketing of higher-burnup fast-reactor fuels, $\mathrm{V}-15 \mathrm{w} / \mathrm{o} \mathrm{Cr}-5 \mathrm{w} / \mathrm{o} \mathrm{Ti}$ specimens fabricated from arc-melted buttons have since shown even better creep properties and compatibility with 
carbide fuels. Test pieces of $\mathrm{V}-5 \mathrm{w} / \mathrm{o}$ Cr that were similarly fabricated have shown notable resistance to corrosion in sodium. In view of such results, a fabricability re-evaluation has prompted a scale-up in the fabrication of both the $\mathrm{V}-15 \mathrm{w} / \mathrm{o} \mathrm{Cr}-5 \mathrm{w} / \mathrm{o} \mathrm{Ti}$ and a binary vanadium-chromium alloy to provide the material needed for a more definitive evaluation of fabrication parameters for rod, sheet, and tubing, and for a comprehensive testing program on finished (wrought) products.

Semiproduction (15-lb) ingots of $\mathrm{V}-15 \mathrm{w} / \mathrm{O} \mathrm{Cr}-5 \mathrm{w} / \mathrm{o} \mathrm{Ti}$ and $\mathrm{V}-10 \mathrm{w} / \mathrm{O} \mathrm{Cr}$ have been consolidated by methods developed for the V-15 w/o Ti-7.5 w/o Cr alloy (see Progress Report for February 1966, ANL-7176, p. 26). Ingot chemistry is shown in Table XIII. Both 3.8-in.-dia ingots were machined, canned, and simultaneously extruded to bar stock. Re-extrusion of rod and sheet-bar billets has been completed, and the. secondary fabrication of the rod and sheet-bar to finished products is pending. A tube-blank billet of each alloy also is available for re-extrusion.

TABLE XIII. Analytical Results for Arc-cast V-15 w/o Cr-5 w/o Ti and $\mathrm{V}-10 \mathrm{w} / \mathrm{O} \mathrm{Cr}$ Ingots

\begin{tabular}{ccc} 
& \multicolumn{2}{c}{ Ingot Number } \\
\cline { 2 - 3 } Alloy Element $(\mathrm{w} / \mathrm{o})^{\mathrm{a}}$ & $\begin{array}{c}\text { AM-97 } \\
(\mathrm{V}-15 \mathrm{Cr}-5 \mathrm{Ti})\end{array}$ & $\begin{array}{c}\text { AM-99 } \\
(\mathrm{V}-10 \mathrm{Cr})\end{array}$ \\
\hline Chromium & 14.4 & 10.2 \\
Titanium & 5.5 & - \\
Interstitial Element $(\mathrm{ppm})^{\mathrm{b}}$ & & 310 \\
\hline Carbon & & 705 \\
Oxygen & 280 & 280 \\
Nitrogen & 900 & 22 \\
Hydrogen & 250 & 1320 \\
\hline Total Interstitials & 13 & 1445 \\
\hline
\end{tabular}

average of three values from top, center, and bottom of ingot.

${ }^{b}$ Average of two values from top and bottom of ingot.

b. Corrosion of Vanadium-base Alloys in Sodium. After 57 days of a continuing test of resistance to corrosion in flowing sodium at $650^{\circ} \mathrm{C}$ (oxygen $<10$ wt ppm) the resistance of $\mathrm{V}-5 \mathrm{w} / \mathrm{o} \mathrm{Cr}$ is still better by an order of magnitude than that of $\mathrm{V}-20 \mathrm{w} / \mathrm{o} \mathrm{T}$.

The progress report for November (ANL-7279, p. 30-32) contained a preliminary discussion of some of the first data developed in this study, and also two misstatements that inadvertently occurred:

$1_{\text {The }} \mathrm{V}-10 \mathrm{w} / \mathrm{O} \mathrm{Cr}$ alloy is favored for scale-up rather than the $\mathrm{V}-5 \mathrm{w} / \mathrm{o} \mathrm{Cr}$ alloy because of greater strength believed to result from the higher chromium content. The fabrication development of $\mathrm{V}-10 \mathrm{w} / \mathrm{o} \mathrm{Cr}$ is, however, expected to be more difficult. 
(1) The sodium velocity in the test at an oxygen concentration of $20 \mathrm{wt} \mathrm{ppm}$ was $15 \mathrm{~cm} / \mathrm{sec}$, not $15 \mathrm{ft} / \mathrm{sec}$.

(2) A logarithmic plot of the depth of the hardened layer versus time of exposure results in straight lines for oxygen concentrations of $20 \mathrm{wt} \mathrm{ppm}$ and $<10 \mathrm{wt} \mathrm{ppm}$. (Since there are only two data points at $20 \mathrm{wt}$ ppm, the significance is uncertain.) The slope of the 20 wt ppm line is 0.50 ; that of the $<10 \mathrm{wt}$ ppm line is 0.37 . It is therefore not accurate to speak of parabolic relationships.

The reported considerable degradation of creep properties of the sample exposed in sodium containing $20 \mathrm{wt}$ ppm oxygen (even after al-. lowing for the decrease in load-bearing area) is of great importance. Of equal importance is the necessity to determine if degradation of creep properties is, in fact, simply related to the thickness of the hardened layer. Accordingly, samples of $\mathrm{V}-20 \mathrm{w} / \mathrm{O} \mathrm{Ti}$ are now being exposed at $650^{\circ} \mathrm{C}$ in sodium, containing $<10 \mathrm{wt}$ ppm oxygen, for the same time that is required to produce the same thickness of $(\sim 30 \mu)$ of hardened layer that is produced after 7 days in. sodium containing 20 wt ppm oxygen.

\section{Fuel Reprocessing}

a. Processes for Fast Reactor Fuels. The pyrochemical processing of fast reactor fuels of the ceramic type (e.g., oxide or carbide) clad with stainless steel is being investigated. A conceptual flowsheet currently under investigation has been described previously (see Progress Report, September 1966, ANL-7255, pp. 30-31). The process utilizes liquid metal-molten salt extractions and salt-transport separations ${ }^{2}$ for the separation of fissile and fertile constituents of the fuel from the fission products.

Chemical studies are being conducted to provide basic data of process importance in the development of the salt-transport concept. Laboratory studies in support of this step have included a determination of the temperature dependence of the solubility of liquid magnesium metal in molten $\mathrm{MgCl}_{2}$. The solubilities were found to increase about twofold over the temperature range from 750 to $850^{\circ} \mathrm{C}$; the concentrations of metallic magnesium were about 0.13 and $0.25 \mathrm{w} / \mathrm{o}$, respectively, at 750 and $850^{\circ} \mathrm{C}$. These studies are of importance for the prediction of the quantity of magnesium which may be transferred in the salt-transport separation step between alloys of different magnesium concentrations.

Engineering studies are being carried out to develop the technology required for plant-scale application of pyrochemical processes.

\footnotetext{
${ }^{2}$ Salt-transport separations are based upon the selective transfer of fissile and fertile materials from one liquid metal solution (donor) to another (acceptor) by cycling a molten salt phase which acts as a carrier between the two metal solutions. Noble and refractory metal fission products remain in the donor alloy.
} 
These studies include the investigation of process concepts on a pilot-plant scale, development of pilot-scale equipment, and evaluation of equipment components. This work requires a variety of experimental and supporting facilities, some of which are described below.

(i) Salt-transport Separations. The engineering feasibility of the salt-transport separation step has been demonstrated with uranium (see Progress Report, July 1966, ANL-7245, p. 14). Similar experiments with plutonium are planned. Until suitable glovebox facilities for pilotplant studies are completed, experiments will be conducted in a walk-intype hood which is capable of safely handling up to $100 \mathrm{~g}$ of plutonium. Installation of the experimental equipment in the hood has been completed and shakedown runs without plutonium are being continued (see Progress Report for November 1966, ANL-7279, p. 37). Information obtained in these experiments will be useful for designing process equipment to be installed later in the glovebox facility. The gloveboxes and components for an inert atmosphere control system have been ordered.

(ii) Pumped Salt Loop. A stainless steel loop (see Progress Report for April 1966, ANL-7204, p. 27) through which molten $50 \mathrm{~m} / \mathrm{o}$ $\mathrm{MgCl}_{2}-30 \mathrm{~m} / \mathrm{o} \mathrm{NaCl}-20 \mathrm{~m} / \mathrm{o} \mathrm{KCl}$ was circulated was successfully operated for $1000 \mathrm{hr}$ at various temperatures between 515 and $600^{\circ} \mathrm{C}$ before being voluntarily shut down. During this period, the loop was utilized for testing equipment items and instruments, which included a centrifugal pump (obtained from Oak Ridge National Laboratory), an induction pressure sensor to measure the pump-discharge pressure, a freeze valve, a bellows-sealed throttle valve, and an orifice flow meter. The loop and its components have performed satisfactorily. Design features of the pump are being incorporated into experimental pumps being developed for pilot-scale pyrochemical process equipment. The salt in the loop was found to contain satisfactorily low levels of corrosion products (iron, nickel, and chromium) and contaminants (oxygen and carbon). Uranium trichloride in molten salt solutions may be involved in pyrochemical processes. Therefore, plans are being made to circulate a molten chloride salt containing $\mathrm{UCl}_{3}$ through the same loop and to use the same components to test the solution stability of $\mathrm{UCl}_{3}$ in stainless steel equipment.

(iii) Liquid Metal-Molten Salt Continuous Contacting Equipment. Batch-processing methods are being developed for current pyrochemical processes. A small experimental effort, however, is being initiated to evaluate the technical feasibility of continuous processing.

(iv) Uranium Removal from Metal Crucible. In the current reference flowsheet, about $16 \mathrm{~kg}$ of uranium mixed with a small quantity of magnesium are accumulated in one of the process crucibles. Removal and recovery of this uranium by dissolution in a $\mathrm{Zn}-\mathrm{Mg}$ solution would require 
retorting large quantities of magnesium-zinc. Previous experiments ${ }^{3}$ showed that it is possible to disintegrate precipitated uranium envoloped in a $\mathrm{Zn}-\mathrm{Mg}$ matrix by a hydriding procedure. However, in the limited number of experiments conducted at that time, it appeared that conversion of the precipitate to a free-flowing powder was not fully successful if the uranium was in low concentration or segregated within the $\mathrm{Zn}-\mathrm{Mg}$ matrix. Since the concentration of uranium in the magnesium matrix in the current reference flowsheet will be considerably higher, it is anticipated that the hydriding procedure will be more successful. Equipment is being assembled to conduct this investigation.

(v) Salt Purification. The pilot-plant facility for makeup and purification of molten chloride salt mixtures (see Progress Report for July 1965, ANL-7082, p. 28) in 100-lb batches has been installed in a new location. The purification procedure that was previously used is being followed. This procedure consists of contacting the impure molten salt with liquid $\mathrm{Cd}-30 \mathrm{w} / \mathrm{O} \mathrm{Mg}$ alloy so as to oxidize the impurities and remove the reaction products by settling and filtering of the supernatant salt. The purified salt is now being discharged to an inert-atmosphere glovebox and cast into a thin slab to permit easy breaking into small pieces. The facility is currently being operated to provide purified salt $(42.5 \mathrm{~m} / \mathrm{o} \mathrm{NaCl}-42.5 \mathrm{~m} / \mathrm{o}$ $\mathrm{CaCl}_{2}-15 \mathrm{~m} / \mathrm{o} \cdot \mathrm{MgCl}_{2}$ ) for pilot-plant testing of the oxide reduction-partition step in the current reference flowsheet.

E. Design Goncept Analysis and Advanced Systems Evaluation

1. $1000-$ MWe Study

At the request of the Division of Reactor Development and Technology, AEC, a meeting was held in Washington on November 30 and December l, which resulted in changes in the proposed contract documents, essentially for clarification purposes. The revised documents were sent to the proposed contractors, and contract negotiation meetings were held at General Electric Company on December 20, and at Atomics International on December 21 .

F. General Research and Development

\section{Fast Reactor Core Parameter Study}

A summary report of the work completed to date on the fast power reactor parameter study has been prepared. This report includes the following:

\footnotetext{
${ }^{3}$ Chemical Engineering Division Semiannual Report, January-June 1965, ANL-7055, pp. 68 and 70-71.
} 
a: derivation of the equations which yield core composition as a function of core geometry, fuel properties, and operating conditions;

b. basis for selection of the values used to describe the fuel properties and operating conditions;

c. dimensional and compositional description of the reactor configurations selected for study;

d. specific techniques employed to study the neutronic characteristics of the above reactors;

e. background assumptions employed in the neutronics calculations;

f. neutronic description of the above reactors.

The remaining work to complete the initial phase of the study is also outlined. This includes consideration of reactors having a core aspect ratio of 0.1 , variation of both radial and axial blanket thicknesses, and calculation of sodium-void coefficients.

The initial work was based on mixed-oxide-fueled cores containing only fuel, coolant, and structure. The parametric study is now being. extended to include the effects of reactor control. A computer code is being developed to select core-subassembly loadings and control dimensions that closely approximate the desired operating conditions for the cylindrical core configurations being studied. This code will later be extended to perform the thermal-hydraulic analysis of cores that have a reduced radial: maximum/average power ratio resulting from radial zoning of fuel enrichment. 


\section{GENERAL REACTOR TECHNOLOGY.}

\section{A. Applied and Reactor Physics Development}

\section{Li $^{6}$ Fast Neutron Spectrometer}

Measurements were made in the center of the core of ZPR- 3 Assembly 48 with the $\mathrm{Li}^{6}$-semiconductor sandwich fast neutron spectrometer. ${ }^{4}$ The device is composed of two silicon surface-barrier detectors mounted with sensitive areas facing each other and separated by a distance approximately equal to the diameter of the sensitive area. Midway between the diodes is a thin organic film, less than $10 \mu \mathrm{g} / \mathrm{sq} \mathrm{cm}$, which is coated with a layer of $\mathrm{Li}^{6} \mathrm{~F}$. The two products $\mathrm{T}$ and $\mathrm{He}$ of the $\mathrm{Li}^{6}, \mathrm{n}$ reaction are detected by the surface-barrier diodes and the output pulses summed to give a pulse proportional in height to the total energy, $Q$ plus neutron energy, of the reaction. Fast coincidence requirements are used to eliminate unrelated events in each detector.

by

The general response of the instrument to a neutron flux is given

$$
\mathrm{C}_{i}=\int_{E_{n}=0}^{E_{\max }} \phi\left(E_{n}\right) \sigma\left(E_{n}\right) K_{i}\left(E_{n}\right) d E_{n},
$$

where $C_{i}$ is the number of events observed in channel i; $\phi\left(E_{n}\right)$ is the neutronenergy spectrum; $\sigma\left(E_{n}\right)$ is the $\mathrm{Li}^{6}(\mathrm{n}, \alpha)$ cross section; and $\mathrm{K}_{\mathrm{i}}\left(\mathrm{E}_{\mathrm{n}}\right) \mathrm{dE}_{\mathrm{n}}$ gives the probability that an event due to a neutron having an energy between $E_{n}$ and $E_{n}+d_{n}$ results in a count in channel $i$.

For the practical case, this equation must be approximated by a matrix equation

$$
C_{i}=\sum_{j=1}^{j=h}\left(K_{i j} \sigma_{j} \phi_{j}\right)
$$

The matrix $\left(K_{i j} \sigma_{j}\right)$ represents the response of the spectrometer. Each column of the matrix describes the spectrometer response to neutrons in the $\mathrm{jth}$ energy channel; that is, each column describes the response to monoenergetic neutrons.

Measurements were made at the center of the core about one inch from the midplane, which is very near: the position where proton-recoil measurements were previously made at a power of about $2.5 \mathrm{~W}$. Following the core runs, the $\mathrm{Li}^{6}$ layer was removed and the background response of the same two diodes was measured and found to be negligible.

${ }^{4}$ Huber, R. J., Trans. ANS 7(2), 368 (1964). 
In order to compare the proton-recoil data (see Progress Report for October 1966, ANL-7267, p. 2l) with the $\mathrm{Li}^{6}$-spectrometer data it is necessary to convert the former to what one would expect if the "sandwich" spectrometer were placed in the spectrum measured by proton-recoil proportional counting. Experience has shown that the difference between these two data at the low-energy end is particularly sensitive to the portion of the neutron spectrum below about $20 \mathrm{keV}$.

The proton-recoil data were converted by use of Eq. (2). To make the calculation of the expected pulse-height distribution, the flux per unit lethargy as given by the proton-recoil experiment was extrapolated linearly to zero at thermal energy. A more rapidly decreasing estimate would have reduced the discrepancy in the low-energy region of the pulse-height distribution. The response matrix $K_{i j}$ was constructed from the thermalneutron response. The full width at half-maximum of the monoenergetic response for this experiment was $72 \mathrm{keV}$.

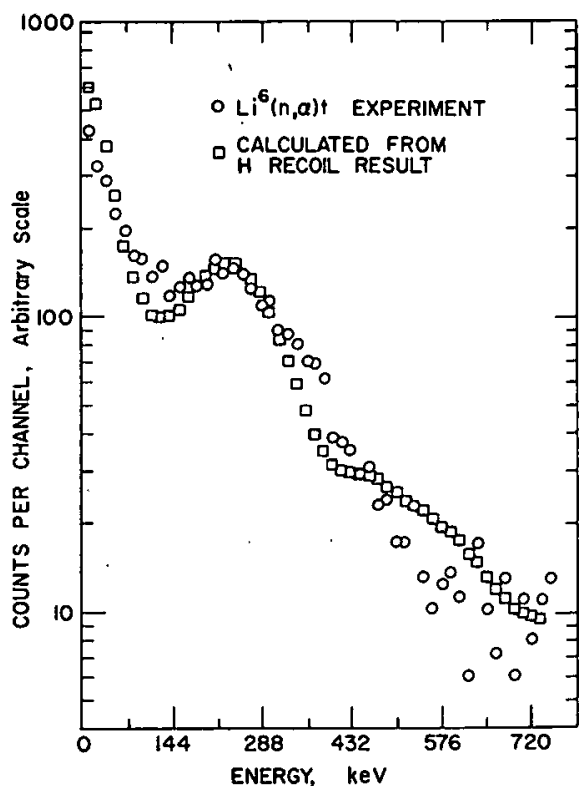

Fig. 8. A Comparison of Spectra as Measured by the $\mathrm{Li}^{6}(\mathrm{n}, \alpha)$ Semiconductor Spectrometer and Proton-recoil Proportional Counters
Figure 8 shows the results of the two counting methods. The agreement between the two is within counting statistics (about 400 counts/channel maximum) except at the peak corresponding to very-low-energy neutrons. This small discrepancy, however, corresponds to a very small difference in total low-energy flux in the core because of the very rapid increase in $L_{i}{ }^{6}(n, \alpha)$ cross section for low energy: In general, the results from the $\mathrm{Li}^{6}$ spectrometer are consistent with those obtained from the proton-recoil measurements.

2. Variational Methods for Two-dimensional Kinetics Calculations

An experimental method of two-spacedimensional, time-dependent reactor analysis is based on the use of the variational method to find the space-dependent flux shapes. The fluxes are fit with quadratic surfaces in the interior of each spatial region, with appropri-

ate boundary conditions. A code which exemplifies this method is

VARI-QUIR; ' which has been developed at Westinghouse Astronuclear Laboratory; VARI-QUIR has been modified and compiled for execution on the CDC-3600 F at ANL.

${ }^{5}$ Riese, J. W., Collier,G., and Riech, C. E., VARI-QUIR, A Two-dimensional Time-dependent Multigroup Diffusion Code, WANL-TNR-133 (revised) (Dec 1965). 
The modifications included substitution of a FORTRAN subroutine ICE, obtained from General Electric Co. (Nuclear Energy Division) for the FAP subroutine supplied by WANL and suitable modifications to the subroutine QUIR. The WANL test problem was successfully executed in $11 \mathrm{~min} 20 \mathrm{sec}$, and agreed with WANL results to one part in $10^{5}$.

Further modification includes cleaning up FORMAT statements, preparing sample feedback routines, and writing an overlay tape.

3. Effects of Cross-section Errors on Neutron Spectra

Errors in cross sections are only indirectly related to errors in spectral indices (see Progress Report for November 1966, ANL-7279, pp. 42-43); the errors in indices can be determined from comparisons of activation and perturbation measurements and calculations. The increasing ability to measure neutron spectra directly and accurately over a wide range suggests that this source be examined as a source of comparison measurements more directly related to cross-section errors.

To this end, consider a hydrogen-like medium in which the ratio of scattering to total cross section, $\sigma_{s} / \sigma_{t}$, is given by

$$
\sigma_{\mathrm{s}} / \sigma_{\mathrm{t}}=1+\epsilon \mathrm{R}(\mathrm{u})
$$

where $R(u)$ is random on $(-1,1) E<<1$, and $u$ is the lethargy variable. The item $\in R(u)$ represents the error in $\sigma_{s} / \sigma_{t}$. In terms of stochastic integrals, ${ }^{6}$, the collision density is given by

$$
F(u)=\int_{\therefore \infty}^{u} F\left(u^{\prime}\right)\left[1+\epsilon R\left(u^{\prime}\right)\right] d u^{\prime} .
$$

Because $\mathrm{R}(\mathrm{u})$ is, $\mathrm{F}(\mathrm{u})$ is random. If we solve by successive approximations

$$
\begin{aligned}
& F_{n}(u)=\int_{-\infty}^{u} F_{n-1}\left(u^{\prime}\right)\left[1+\epsilon R\left(u^{\prime}\right)\right] d u^{\prime} ; \\
& F_{0}(u)=e^{u}
\end{aligned}
$$

\footnotetext{
${ }^{6}$ Papoulis, A., Probability, Random Variables and Stochastic Processes, McGraw-Hill Book Co., Inc., (1965), pp, 323 et seq.
} 
Then to the second order in $\epsilon$,

$$
\begin{aligned}
F_{2}(u)= & e^{u}+\epsilon\left[\int_{-\infty}^{u} d u^{\prime} e^{u^{\prime}} R\left(u^{\prime}\right)+\int_{-\infty}^{u} d u^{\prime} \int_{-\infty}^{u^{\prime}} d u^{\prime \prime} e^{u^{\prime \prime}} R\left(u^{\prime \prime}\right)\right] \\
& +\epsilon^{2} \int_{-\infty}^{u} d u^{\prime} R\left(u^{\prime}\right) \int_{-\infty}^{u} d u^{\prime \prime} e^{u^{\prime \prime} R\left(u^{\prime \prime}\right),}
\end{aligned}
$$

and

$$
\phi_{2}(u)=[1+R(u)] F_{2}(u)
$$

is the neutron.flux spectrum.

The average value of $\phi$, the mean deviation, and the autocorrelation can all be defined, to order $\epsilon$, from the expression for $\phi_{2}(u)$ and the properties of $R$.

Two random signals are easily used to exemplify cross-section errors:

i. the pseudorandom telegraph signal, ${ }^{7}$ which has the property

$$
\begin{aligned}
R(u) & =1 \text { if } R(u)=0 \text { an even number of times in }(0, u) ; \\
& =-1 \text { if } R(u)=0 \text { an odd number of times in }(0, u)
\end{aligned}
$$

and the zeros of $R$ are distributed randomly with density $\dot{\lambda}$.

2. The random telegraph signal:

$$
\mathrm{R}(\mathrm{u})=\text { the preceding process times } \mathrm{a}(\mathrm{u})
$$

where $a= \pm 1$ with equal probability.

In the first case, the expectation value of $R$ is $e^{-2 \lambda \mid}|\mathrm{u}|$ and the autocorrelation is $e^{-2 \lambda \mid u-u ' j}$. In the second case the expectation value is 0 and the autocorrelation is $e^{-2 \lambda \mid u-u} \mid$. By means of properties and the commutivity of the operation of integration and expected value, the expected value of $\phi_{2}$ and its square àre readily found.

${ }^{7}$ See Ref. 6, pp. 288-289. 
4. The ARC System

a. Operation. Figure 9 schematically illustrates the operation of the ARC System. The Operating System manages the data handling and module linkages as well as dealing with user input and output information.

The standard-path modules are control programs which call ARC modules to accomplish a particular task. The module-calling sequence in a standard path can be influenced by results obtained earlier in the

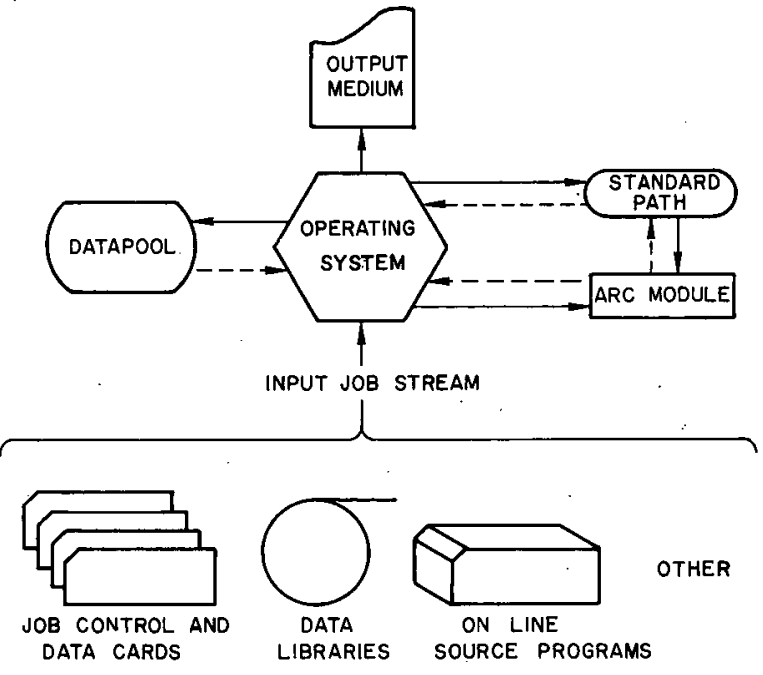

Fig. 9. Schematic Diagram of ARC System, Showing Standard Path and F ARC Module Arrangements path. The standard paths and other ARC modules are stored in the module-library portion of the ARC Datapool.

Figure 9 represents a condition in the computer in which the Operating System has transferred one of the standard paths and one of the modules from the Datapool to the Fast Memory.

Table XIV reflects the current thinking in regard to the $A R C$ module library for the system. The module names are intended to be descriptive of the function of the modules and correspond to the Module Name or Designation in the module documentations which are now being prepared for inclusion in an ANL topical report describing the ARC System.

The listing has been grouped into five main categories. Within each category the modules are further organized into Input, Computational, and Output Edit modules. In all categories, a blank entry has been included to imply the open ended nature of the module library.

TABLE XIV. ARC System Modules

I. Cross-section-preparation Modules

A. Input Modules

1. Epithermal-cross-section Specifications

2. Thermal-cross-section Specifications

3. Broad-group Specifications

4. Broad-group Fundamental-mode Specifications

5. 
.TABLE XIV. (Contd.)

B. Computational Modules

1. Resonance Cross Sections

2. Nonresonant Cross Sections and Fundamental-mode Spectrum

3. Thermal Cross Sections

4. Broad-group Cross Sections

5. Broad-group Fundamental-mode Spectrum

6.

C. Output Edit Modules

1. Resonance-cross-section Edit

2. Nonresonant-cross-section and Spectrum Edit

3. Thermal-cross-section Edit

4. Broad-group Edit

5. Broad-group Fundamental-mode Edit

6.

II. Neutronics Calculations Modules

A. Input Modules

1. Neutronics Specifications

2. Geometry Preparation

3. Cross-section-homogenization Specifications

4. 1D-Diffusion Specifications

5. 1D-Transport Specifications

6. 2D-Diffusion Specifications

7. 2D-Transport Specifications

8. Diffusion Mesh-refinement Specifications

9. Transport Mesh-refinement Specifications

10. Neutronics Output Manipulation Specifications 11.

B. Computational Modules

1. Cross-section Homogenization

2. 1D-Diffusion

3. 1D-Transport

4. 2D-Diffusion

5. 2D-Transport

6. Diffusion Mesh Refinement

7. Transport Mesh Refinement

8. Criticality Search

9. Neutronics Output Manipulation 10.

C. Output Edit Modules

1. 1D-Diffusion Edit

2. 1D-Trànsport Eḋit

3. 2D-Diffusion Edit

4. 2D-Transport Edit

5 . 
TABLE XIV. (Contd.)

III. Adjunct Calculations Modules

A. Input Modules

1. Neutron-inventory Specifications

2. Diffusion-perturbation Specifications

3. Transport-perturbation Specifications

4. Spatial-synthesis Specifications

5. Group-collapse Specifications

6. Bivariate Cross-section-interpolation Specifications

7.

B. Computational Modules

1. Neutron Inventory

2. Diffusion Perturbation

3. Transport Perturbation

4. Spatial Synthesis

5. Group Collapse

6. Bivariate Cross-section Interpolation

7.

C. Output Edit Modules

1. Neutron-inventory Edit

2. Diffusion-perturbation Edit

3. Transport-perturbation Edit

4. Spatial-synthesis Edit

5. Group-collapse Edit

6. Bivariate Cross-section-interpolation Edit

7.

IV. Fuel Cycle and Depletion Calculations Modules

A. Input Modules

1. Fuel-cycle Specifications

2. Economics Specifications

3.

B. Computational Modules

1. Fuel Cycle

2. Economics

3.

C. Output Edit Modules

1. Fuel-cycle Edit

2. Economics Edit

3.

V. Safety and Accident Calculations Modules

A. Input Modules

1. Point-kinetics Specifications

2. Spatial-kinetics Specifications 
TABLE XIV. (Contd.)

3: Heat-transfer Specifications

4. Two-phase Coolant-flow Specifications

5.: Core-compaction Specifications

6. Compressible-fluid-hydrodynamics:Specifications

7. Fuel-element-deformation Specifications

8. Initiating-mechanism Specifications

9. Fuel-Coolant Interaction Specifications 10 .

B. Computational Modules

1. Point Kinetics

2. Spatial Kinetics

3. Heat Transfer

4. Two-phase Coolant Flow

5. Core Compaction

6. Compressible Fluid Hydrodynamics

7. Fuel-element Deformations

8. Initiating Mechanisms

9. Fuel-Coolant Interaction 10.

C. Output Edit Modules

1. Point-kinetics Edit

2. Spatial-kinetics Edit

3. Heat-transfer Edit

4. Two-phase Coolant-flow Edit

5. Core-compaction Edit

6. Compressible-fluid-hydrodynamics Edit

7. Fuel-element-deformation Edit

8. Initiating-mechanism Edit

9. Fuel-Coolant Interaction Edit

10 .

b. Burnup Calculations. The Phase-zero burnup package effort (see Progress Report for August 1966, ANL-7249, pp. 40-41) is complete in most essential features. An equilibrium test case has been successfully compared with the CYCLE-1 code. Methods for accelerating the iteration steps for the external cycle are being developed:" Further improvement of the core cycle search procedures may, be possible, depending on the results of this effort.

Preliminary ARC documentation of the Phase-1. (see Progress Report for May: 1966, ANL-7219, pp. 34-35) specifications has been. completed. The Phase-1 package for the IBM 360 Model 50 has been completely flowcharted and coded. Debugging of this package will begin in the near future. 
The input modules have BCD upper interface data sets while the computational modules deal only with binary data sets. The edit modules have both BCD and binary upper interface data sets. Eventually, quite selective edits should be possible, depending upon user choice. At the moment, most edit modules will probably be similar to the classical code output routines in that the user either does or does not get the programmed output. 


\section{B. Fuels and Cladding}

\section{Irradiation of High-temperature Materials}

Last month UC-20 w/o PuC, PuC and US, each in an $\mathrm{Nb}-1 \mathrm{w} / 0 \mathrm{Zr}$ jacket at $750^{\circ} \mathrm{C}(\max )$, had attained maximum burnups of $6.9,1.8$, and $7.2 \mathrm{a} / \mathrm{o}$ of $(\mathrm{U}+\mathrm{Pu}), \mathrm{Pu}$, or $\mathrm{U}$, respectively, and electron-microscopical studies were initiated of fission-product distribution (gas and solid) of vibrationally compacted UC-20 w/o Pu after 6.9 a/o burnup. The irradiations, which are being made in instrumented capsules in MTR, are summarized in Table XV.

\begin{tabular}{|c|c|c|c|c|c|c|c|c|c|}
\hline \multirow{3}{*}{$\begin{array}{c}\text { Capsule } \\
\text { or S/A No. }\end{array}$} & \multirow{3}{*}{$\begin{array}{l}\text { Specimen } \\
\text { Number }\end{array}$} & \multicolumn{4}{|c|}{ Design Parameters } & \multicolumn{4}{|c|}{ Operating Conditions } \\
\hline & & \multirow{2}{*}{$\begin{array}{l}\text { Fuel } \\
\text { Composition } \\
\text { (w/o) }\end{array}$} & \multirow{2}{*}{$\begin{array}{c}\text { Effective } \\
\text { Density } \\
(\%)\end{array}$} & \multirow{2}{*}{$\begin{array}{l}\text { Cladding } \\
\text { OD (in.) }\end{array}$} & \multirow{2}{*}{$\begin{array}{c}\text { Cladding } \\
\text { Thickness } \\
\text { (in.) }\end{array}$} & \multirow{2}{*}{$\begin{array}{l}\text { Power } \\
\text { Density } \\
(\mathrm{kW} / \mathrm{cc})^{\mathrm{a}}\end{array}$} & \multirow{2}{*}{$\begin{array}{c}\text { Max } \\
\text { Cladding } \\
\text { Temp }\left({ }^{\circ} \mathrm{C}\right)\end{array}$} & \multicolumn{2}{|c|}{ Burnup to Date } \\
\hline & & & & & & & & $a / o(U+P u)$ & fiss/cc $\times 10^{-20}$ \\
\hline $56-11$ & $M V-2$ & UC-20 PuC & 79 & 0.281 & 0.021 & 1.2 & 470 & 6.6 & 17.0 \\
\hline $56-8$ & $M V-3$ & UC-20 PuC & 81 & 0.281 & 0.012 & 1.2 & 715 & 7.1 & 18.8 \\
\hline $56-8$ & $M V-5$ & UC-20 PuC & 80 & 0.281 & 0.012 & 1.2 & 705 & 6.8 & 17.8 \\
\hline $56-11$ & $M V-6$ & $U C-20$ PuC & 80 & 0.281 & 0.012 & 1.2 & $480^{\circ}$ & 7.1 & 18.6 \\
\hline $56-13$ & $Z-4$ & UC-20 PUC & 79 & 0.174 & 0.015 & 1.2 & 665 & 2.0 & 5.2 \\
\hline $56-13$ & $\bar{z}-5$ & UC- 20 PUC & 79 & 0.174 & 0.015 & 1.2 & 585 & 2.0 & 5.2 \\
\hline $56-13$ & $Z-7$ & UC-20 PuC & 79 & 0.174 & 0.015 & 1.2 & 570 & 2.0 & 5.2 \\
\hline $56-13$ & $C-45$ & PuC & 84 & 0.174 & 0.009 & 1.4 & 700 & 2.0 & 5.5 \\
\hline $56-8$ & $S-7$ & US & 80 & 0.281 & 0.012 & 1.0 & 535 & 5.4 & 10.5 \\
\hline $56-8$ & S-8 & US & 89 & 0.281 & 0.012 & 1.0 & 725 & 7.4 & 16.0 \\
\hline $56-8$ & $5-9$ & US & 76 & 0.281 & 0.012 & 1.0 & 750 & 7.4 & 13.6 \\
\hline $56-8$ & $5-10$ & US & 91 & 0.281 & 0.012 & 1.0 & 690 & 7.4 & 16.4 \\
\hline $56-11$ & $5-15$ & US & 82 & 0.281 & 0.012 & 1.0 & 380 & 4.5 & 9.0 \\
\hline $56-11$ & S-16 & US & 90 & 0.281 & 0.012 & 1.0 & 510 & 6.4 & 14.0 \\
\hline $56-11$ & S-17 & US & 88 & 0.281 & 0.012 & 1.0 & 500 & 5.1 & 10.9 \\
\hline $56-11$ & S-18 & US & 77 & 0.281 & 0.012 & 1.0 & 610 & 6.9 & 12.9 \\
\hline
\end{tabular}

abased on effective density.

\section{Radiation Damage to Structural Materials}

a. Effect of Fast-neutron Irradiation on Jacket Materials. An investigation of irradiation with respect to tensile, creep, creep-rupture, and tube-rupture properties of $\mathrm{V}-20 \mathrm{w} / 0 \mathrm{Ti}, \mathrm{V}-15 \mathrm{w} / \mathrm{O} \mathrm{Ti}-7.5 \mathrm{w} / \mathrm{o} \mathrm{Cr}$, AISI Type 304 stainless steel, Hastelloy-X, and Inconel 625 is in progress for the exposure range of $10^{21}$ to $10^{23} \mathrm{n} / \mathrm{cm}^{2}$ at temperatures in the range from 400 to $750^{\circ} \mathrm{C}$. Twenty-six tensile-type specimens of $\mathrm{V}-20 \mathrm{w} / \mathrm{o} \mathrm{Ti}$, three of Hastelloy $-\mathrm{X}$, and ten of Type 304 stainless steel were removed from EBR - II last November after an exposure of $2.7 \times 10^{22} \mathrm{n} / \mathrm{cm}^{2}$ at $670^{\circ} \mathrm{C}$, but 24 capsules, containing 103 tube-burst specimens and 321 tensile-type specimens are being irradiated in EBR-II subassemblies XA08, XO10, and XO1 8 at temperatures between 500 and $650^{\circ} \mathrm{C}$. These specimens have accumulated maximum total neutron exposures in the range from $4 \times 10^{20}$ up to $1.6 \times 10^{22} \mathrm{n} / \mathrm{cm}^{2}$. The status and identification of these capsules are given in Table XVI. 
TABLE XVI. Status of Cladding Materials Irradiations in EBR-II

\begin{tabular}{|c|c|c|c|c|c|c|c|}
\hline \multirow[b]{2}{*}{ S/A No. } & \multirow[b]{2}{*}{$\begin{array}{l}\text { Capsule } \\
\text { Number }\end{array}$} & \multicolumn{4}{|c|}{ Design Parameters } & \multicolumn{2}{|c|}{ Operating Conditions } \\
\hline & & $\begin{array}{l}\text { Cladding } \\
\text { Composition }\end{array}$ & $\begin{array}{l}\text { Type of } \\
\text { Specimen }\end{array}$ & $\begin{array}{l}\text { No. of } \\
\text { Specimens }\end{array}$ & $\begin{array}{c}\text { Specimen } \\
\text { Environment }\end{array}$ & $\begin{array}{l}\text { Max Specimen } \\
\text { Temp }\left({ }^{\circ} \mathrm{C}\right)\end{array}$ & $\begin{array}{l}\text { Exposure to Date } \\
\left(\mathrm{n} / \mathrm{cm}^{2}\right)\end{array}$ \\
\hline $\begin{array}{l}\text { XA08 } \\
\text { XA08 } \\
\text { XA08 } \\
\text { XA08 } \\
\text { XA08 } \\
\text { XA08 } \\
\text { XA08 } \\
\text { XA08 } \\
\text { XA08 }\end{array}$ & $\begin{array}{l}\text { AS-1 } \\
\text { AS-2 } \\
\text { AS-3 } \\
\text { AS-4 } \\
\text { AS-5 } \\
\text { AS-6 } \\
\text { AS-7 } \\
\text { AS-8 } \\
\text { AS- } 12\end{array}$ & $\begin{array}{c}\text { V-20w/oTi } \\
\text { V-20w/o Ti } \\
\text { Hastelloy-X } \\
\text { Hastelloy-X } \\
304 \text { SS } \\
\text { V-20w/o Ti } \\
\text { Hastelloy-X } \\
304 \text { SS } \\
\text { V-20w/o Ti }\end{array}$ & $\begin{array}{c}\text { Tube-burst } \\
\text { Tube-burst } \\
\text { Tube-burst } \\
\text { Tube-burst } \\
\text { Tube-burst } \\
\text { Tensile } \\
\text { Tensile } \\
\text { Tensile } \\
\text { Tensile }\end{array}$ & $\begin{array}{l}12 \\
12 \\
12 \\
12 \\
12 \\
16 \\
16 \\
16 \\
16\end{array}$ & $\begin{array}{l}\text { Argon-helium } \\
\text { Argon-helium } \\
\text { Argon-helium } \\
\text { Argon-helium } \\
\text { Argon-helium } \\
\text { Argon-helium } \\
\text { Argon-helium } \\
\text { Argon-helium } \\
\text { Argon-helium }\end{array}$ & $\begin{array}{l}540 \\
540 \\
540 \\
540 \\
540 \\
580 \\
580 \\
580 \\
580\end{array}$ & $\begin{array}{l}3.4 \times 10^{22} \\
3.4 \times 10^{22} \\
3.6 \times 10^{22} \\
3.6 \times 10^{22} \\
3.6 \times 10^{22} \\
3.7 \times 10^{22} \\
3.4 \times 10^{22} \\
3.4 \times 10^{22} \\
3.3 \times 10^{22}\end{array}$ \\
\hline $\begin{array}{l}X 010 \\
\times 010 \\
X 010 \\
X 010 \\
X 010 \\
X 010 \\
\times 010 \\
X 010 \\
X 010 \\
X 010 \\
X 010\end{array}$ & $\begin{array}{l}\text { AS-16 } \\
\text { AS-17 } \\
\text { AS-18 } \\
\text { AS-19 } \\
\text { AS-20 } \\
\text { AS-21 } \\
\text { AS-22 } \\
\text { AS-23 } \\
\text { AS-24 } \\
\text { AS- } 25 \\
\text { AS-26 }\end{array}$ & $\begin{array}{c}\text { V-20w/o Ti } \\
\text { V-20w/o Ti } \\
\text { V-20w/0 Ti } \\
\text { V-20w/o Ti } \\
\text { V-20w/o Ti } \\
\text { V-20w/o Ti } \\
\text { Hastelloy-X } \\
304 \text { SS } \\
304 \text { SS } \\
304 \text { SS } \\
304 \text { SS }\end{array}$ & $\begin{array}{l}\text { Tensile } \\
\text { Tensile } \\
\text { Tensile } \\
\text { Tensile } \\
\text { Tensile } \\
\text { Tensile } \\
\text { Tensile } \\
\text { Tensile } \\
\text { Tensile } \\
\text { Tensile } \\
\text { Tensile }\end{array}$ & $\begin{array}{l}13 \\
13 \\
13 \\
13 \\
13 \\
13 \\
13 \\
13 \\
13 \\
13 \\
13\end{array}$ & $\begin{array}{l}\text { Argon-helium } \\
\text { Argon-helium } \\
\text { Argon-helium } \\
\text { Argon-helium } \\
\text { Argon-helium } \\
\text { Argon-helium } \\
\text { Argon-helium } \\
\text { Argon-helium } \\
\text { Argon-helium } \\
\text { Argon-helium } \\
\text { Argon-helium }\end{array}$ & $\begin{array}{l}500 \\
500 \\
500 \\
500 \\
500 \\
500 \\
500 \\
500 \\
500 \\
500 \\
500\end{array}$ & $\begin{array}{l}1.2 \times 10^{22} \\
1.3 \times 10^{22} \\
1.2 \times 10^{22} \\
1.2 \times 10^{22} \\
1.4 \times 10^{22} \\
1.6 \times 10^{22} \\
1.4 \times 10^{22} \\
1.6 \times 10^{22} \\
1.4 \times 10^{22} \\
1.3 \times 10^{22} \\
1.3 \times 10^{22}\end{array}$ \\
\hline$x 018$ & AS-56 & $\begin{array}{l}\text { V-20 w/o Ti, } \\
\text { V-15 w/o Ti- } \\
7.5 \mathrm{w} / 0 \mathrm{Cr} \\
304 \mathrm{SS},\end{array}$ & $\begin{array}{l}\text { Tensile, } \\
\text { Tube-burst }\end{array}$ & 75 & $\mathrm{NaK}$ & 650 & $4.0 \times 10^{20}$ \\
\hline X018 & AS -58 & $\begin{array}{l}\text { Hastelloy-X } \\
\text { V-20 w/o Ti, } \\
\text { V-15 w/o Ti- } \\
7.5 \text { w/o Cr. }\end{array}$ & $\begin{array}{l}\text { Tube-burst } \\
\text { Tensile, } \\
\text { Tube-burst }\end{array}$ & 25 & NaK & 650 & $4.0 \times 10^{20}$ \\
\hline
\end{tabular}

EBR-II subassembly XA07, containing 48 tensile-type specimens made severally of $\mathrm{V}-20 \mathrm{w} / \mathrm{o} \mathrm{T}$, Hastelloy $-\mathrm{X}$, and Type 304 stainless steel, was removed after accumulating a maximum total neutron exposure of $3.8 \times 10^{22} \mathrm{n} / \mathrm{cm}^{2}$. Arrangements are now being made to ship the specimens to the Illinois site. EBR-II subassembly XO18, containing 63 tube-burst specimens and 112 tensile-type specimens of V-20 w/o Ti, V-15 w/o Ti$7.5 \mathrm{w} / \mathrm{o} \mathrm{Cr}$, Hastelloy-X, and Type 304 stainless steel, was inserted in Row No. 2 during this report period for irradiation to $1 \times 10^{23} \mathrm{n} / \mathrm{cm}^{2}$ at $650^{\circ} \mathrm{C}$.

As an aid to an interpretation of the results being obtained, a characterization of the neutron spectra (flux and energies) in EBR-II has become highly desirable. A special short run at low power is therefore to be made at EBR -II when the core is loaded to full size. Assemblies have been constructed (by Argonne National Laboratory, Idaho Division) that can accommodate capsules for irradiation of detecting foils.

Stainless steel capillary tubes have been loaded with iron, nickel, copper, titanium, and aluminum-cobalt wires. These have been shipped to EBR-II for inclusion with other experiments in the special capsules. Calculations of the neutron spectra in the EBR-II core and blanket are being analyzed for application to the experimental data that will be obtained from the foils. 
3. Techniques of Fabrication and Testing

a. Tungsten-base Alloy Tubing. For the past several years, a long-range program has been.under way at Argonne National Laboratory.. to devise and develop a practical technology for the fabrication of tungsten and tungsten-alloy tubing for high-temperature applications. Since July 1966 , a change in programming has permitted a much-needed concentration on process development with less emphasis on the delivery of high-quality finished tubing for application evaluation.

The existing technology ${ }^{8}$ consists of primary fabrication by the "filled-billet" extrusion technique. Although this method has consistently produced high-quality tube-blanks, minor surface striations have plagued subsequent processing. Secondary fabrication has followed two alternative warm-drawing routes: ductile-core drawing or plug-drawing. In the former method the metal core is retained in the tube until after extrusion, and drawing to the final tube size. The core is then removed by acid dissolution. This is an unattractive and time-consuming process, the time for core removal being dependent upon the final inner diameter and length of the tubing. Plug-drawing is performed on the extruded tube-blank after core removal.

All of the above fabrication operations have been beset with difficulties such as surface striations resulting from the extrusion operation, lubrication problems, swage pointing failures, tooling inadequacies, and many others. Some of these difficulties have received attention; some remain to be resolved.

The continued application of the extrusion technique to billets that are "filled" or canned for mandrel use requires that means for economic conditioning of the extruded tube-blank be considered. Since one such method is tube-reduction, the Argonne National Laboratory three-roll tube-reducer is being modified for warm working operations (see Progress Report for November 1966, ANL-7279, pp. 57-58). By tube-reduction of some extruded W-Re-Mo alloy, we have successfully improved both the outer and inner surfaces. This work will continue and, it is hoped, be extended to tungsten and to tungsten-rhenium alloys, both of which are more difficult to fabricate than the ternary alloy.

A variety of lubricants are being. evaluated. Early results indicate that an alcohol dispersion of $\mathrm{WS}_{2}$ can produce a better drawn surface than that obtained with the formerly used graphite-sugar-water mixture. Conventional cold-swaging dies have been substituted for the hot-working dies: previously used, and furnace-tip heating has been replaced by inductive $(R F)$ heating. Considerably improved swaged-tip surfaces have resulted.

8 Burt, W. R., Jr., et al., ANL-7151 (July 1966), Development of Techniques for Fabrication of Smalldiameter Thin-wall Tungsten and Tungsten-alloy Tubing, Interim Progress Report Covering the Period from January 1, 1964 through December 31, 1965. 
Improvements in swage-pointing have resulted in more successful final drawing operations. Attempts to improve the economics of these operations by: eliminating both drawing and annealing sequences have met with some success and continued effort will be concentrated in this area.

\section{Engineering Development}

1. Electric Master-Slave Manipulator, Mark E4A

The electrically. actuated brakes for the slave-arm motions (see Progress Report for' November 1966, ANL-7279, p. 60) have been completed in design and detail; some parts are on order. Clutches, preset at about $3 / 4$ of the maximum load capacity of each motion, are incorporated to protect the manipulator from external loads when the brakes are on. The brakes will be automatically set by springs whenever there is an electrical interruption or electrical malfunction as indicated by a special safety circuit. The brakes can also be set by switches on the handle.

The stiffness of the $\mathrm{Z}$ motion, when in $1: 1$ force ratio, has been increased by a factor of three. This was brought about by changes in the amplifier, that is, by use of a ring modulator and by increasing the tachomete $r$ and positional gains. High-precision bearings on the output shaft of the $\mathrm{Z}$-motion gear box were installed to reduce the mechanical backlash. The increased stiffness. and decreased backlash improve the "feel" considerably, and it is planned to make these changes in the other motions.

A new synchro gear system has been designed and is being detailed. The new gear ratio will increase the synchro null spacings from about 8 to 32 in. (as measured at the wrist joint) in the $X, Y$, and $Z$ motions. This should eliminate inadvertent "jumping" of nulls when the slave arm is overloaded. The position signal will be reduced by a factor of four, but tests show that the signal-to-noise ratio is still acceptable.

\section{Studies of Structural Dynamics of Core}

By means of a combined theoretical and experimental program, structure-fluid interactions will be studied as they relate to the performance, stability, and reliability of reactor core components.

The initial effort, related to the theoretical phase, will be an indepth analysis of literature in the field of flow-induced vibration. The outcome will be a survey report discussing possible excitation mechanisms and the nature of fluid-structure coupling, presenting. the state-of-the-art in explaining and predicting observed vibration phenomena, and outlining theoretical approaches to be pursued. 
An experimental program will be run concurrently. The first phase will be a laboratory experiment to demonstrate the phenomena of parallel flow-induced vibration of rods. Towards this end, a small bench-top flow loop is presently being constructed.

The pump, chosen because of its availability, has a maximum flowrate of approximately $30 \mathrm{gpm}$. The test set-up features a removable test section, $2 \frac{3}{16} \mathrm{in}$. in diameter and $34 \mathrm{in}$. long. The test section will accommodate rods, up to $30 \mathrm{in.}$. in length, of various materials and cross sections. For initial tests, circular brass rods of $0.063-, 0.090-$, and $0.125-\mathrm{in}$. dia have been chosen.

The tests are intended to demonstrate measurable oscillations of the rods. Future tests will be instrumented to measure pressure, displacements and strains, thus yielding pressure-and displacement-time histories which can be analyzed for harmonic content or correlated, leading to further insight into the overall problem and design of experiments.

3. Heat Transfer, Fluid Flow, and Mechanics of Materials

\section{a. Boiling Liquid Metal Technology}

(i) Niobium-1\% Zirconium Loop. This facility is designed to investigate the heat transfer and two-phase flow characteristics of boiling sodium to a temperature of $2100^{\circ} \mathrm{F}$ and a pressure of approximately $8 \mathrm{~atm}$. Among the variables to be investigated are boiling heat flux and temperature difference up to the occurrence of critical flux, boiling and adiabatic twophase pressur'é losses, vapor volume fraction, boiling-stability parameters, and ultimately the transient behavior of some of these same quantities.

${ }^{r}$ Operation of the vacuum chamber was initiated early in December. Aftér several days of pump-down, malfunctions of the partialpressure analyzer and of one ion gauge were detected and testing discontinued. Inspection of the mass-spectrometer tube revealed a thin. film of copper oxide over several surfaces; the-tube was dismantled and thoroughly cleaned. The ion gauge has been replaced.

Several other modifications were completed: an alarm was incorporated into the ion-gauge-circuit to warn of very small increases in vacuum chamber pressure; a 500--W quartz lamp was installed to provide better porthole observation of loop components during high-temperature operation; a $50-\mathrm{kW}$ wattmeter was installed for monitoring boiler power; several auxiliary thermocouples were installed at supplementary loop positions; the new power supplies for the pressure transducers were installed; an initial sodium sample was taken from the dump tank, the first of several samples to be taken during long-term loop operation; the argon-clean-up system is being modified to allow the use of very pure argon for fieldwelding experiments. 
(ii) Electron-bombardment Heater (EBH) Experiment. This experiment has been shut down due to a failure at the outside wall of the sodium vessel. This vessel has been repeatedly exposed to temperature greater than $1600^{\circ} \mathrm{F}$, and it is questionable whether or not this facility is still useful. A total of $900 \mathrm{hr}$ of testing at heat fluxes up to $350,000 \mathrm{~B} /$ $\mathrm{hr}-\mathrm{ft}^{2}$ (anode flux) have been completed, and this is in excess of the originally planned life of the experiments. Although a short, high-powered energy burst was planned for the final test, it appears that tests at higher flux should be made in the forthcoming EBH test facility. now under design. A description of this new facility and its application to EBH designs for liquid metal loops will be described in a subsequent progress report.

\section{b. General Heat Transfer}

(i) Countercurrent Turbulent Liquid Metal Flow. The impeller of the canned-rotor pump. has been "reworked" for mercury operation and replaced in the pump. Tests in the mercury flow loop showed that the pump now performs satisfactorily. Installation of the second heat-exchanger test section, as well as loop clean-up, are in progress. Design of the third test section continues.

Recent analytical studies concentrated on extentions of the special treatment required for the case of equal heat capacity mass flowrates on both sides of the exchanger, and on attempts to find an improved computational procedure for applying the existing mathematical solution for counter-flow heat exchangers. The former is being reformulated for application to cases of practical interest and future publication; the latter has not been successful.

(ii) Nonsymmetrical Geometries. Fabrication of a small heat transfer loop for the purpose of performing experiments with sodium in model heat exchangers has" begun.

(iii) Liquid-metal -heated Steam Generators. Basic research on heat exchangers for use in liquid-metal-heated steam generators has begun. Information related to the heat transfer design and operation of existing liquid-metal-heated steam generators is being collected.

c. Effects of Interfacial Transport Processes on Film Condensation. Modification of the film injector has been completed, and the loop is operative. Flow patterns in the film have been studied by use of the dye-injection technique. At both high and low water and air flows, the streamlines across the channel width were found to be parallel. These results indicate that the desired two-dimensional flow pattern has been achieved and that secondary flows have been eliminated. 
The entrance effects resulting from the exchange of momentum between the air and water streams will now be studied. During these runs, different types of instrumentation for measuring film thickness will be tested.

\section{Chemistry and Chemical Separations}

\section{Fluoride Volatility Processes}

a. Recovery of Uranium and Plutonium from Low-enrichment Fuels: Laboratory Support Work

(i) Fluorination of $\mathrm{UO}_{2}-\mathrm{PuO}_{2}$-Fission Product Pellets. Development studies are being performed in a 2 -in.-dia fluid-bed reactor to establish optimum conditions for fluorinating $\mathrm{UO}_{2}-\mathrm{PuO}_{2}$ pellets containing fission . products. Current emphasis in these studies is on the use of $\mathrm{BrF}_{5}$ as a selective fluorinating:agent for conversion of uranium oxides: in uraniumplutonium mixtures to volatile $U_{6}$. In this reaction, plutonium is converted to nonvolatile $\mathrm{PuF}_{4}$. Recovery of plutonium as volatile $\mathrm{PuF}_{6}$ is effected in a subsequent step by reaction of $\mathrm{PuF}_{4}$ with fluorine. A recent experiment (Purse-13) was performed as one of a series of experiments to determine the effect of the temperature of the $\mathrm{BrF}_{5}$ fluorination step upon plutonium retention in the final alumina bed. In: previous experiments of this series, $\mathrm{BrF}_{5}$ fluorination temperatures of $200^{\circ} \mathrm{C}$ (see Progress Report for April 1966, ANL-7204, p. 63), $300^{\circ} \mathrm{C}$ (see Progress Report for February: 1966, ANL-7176, p. 65), and $400^{\circ} \mathrm{C}$ (see Progress Report for July 1966, ANL-7245, pp. 45-46) were-evaluated. In the recent experiment, the $\mathrm{BrF}_{5}$ fluorination step was carried out at $250^{\circ} \mathrm{C}$. The charge to the reactor in Run Purse -13 consisted of $650 \mathrm{~g}$ of pellets and $1100 \mathrm{~g}$ of alumina containing $0.6 \mathrm{~g} \mathrm{CsF}$ and $0.15 \mathrm{~g} \mathrm{RbF}$. The processing sequence consisted of: oxidation of the pellets for $4 \mathrm{hr}$ at $450^{\circ} \mathrm{C}$ with $20 \mathrm{v} / 0$ oxygen, fluorination with $8-10 \mathrm{v} / \mathrm{o} \mathrm{BrF}_{5}$ at $250^{\circ} \mathrm{C}$ for $2.8 \mathrm{hr}$, and fluorination with $90 \mathrm{v} / 0$ fluorine for $3 \mathrm{hr}$ at $300^{\circ} \mathrm{C}$, $5 \mathrm{hr}$ while the reactor temperature was increased from 300 to $550^{\circ} \mathrm{C}$, and $3 \mathrm{hr}$ at $550^{\circ} \mathrm{C}$.

The final alumina bed contained $0.005 \mathrm{w} / \mathrm{o}$ uranium and $0.007 \mathrm{w} / \mathrm{O}$ plutonium, which corresponds to the removal of more than $99.9 \%$ of the uranium and $97.3 \%$ of the plutonium present in the charge. These residual concentrations are nearly identical to those obtained using a $B r F_{5}$ fluorination temperature of $300^{\circ} \mathrm{C}$ (see ANL-7176, p. 65), which were the lowest values achieved in the three prior experiments. Plutonium removals of $99 \%$ can beachieved by reuse of the alumina bed (see Progress Report for October 1966, ANL-7267, p. 66). On the basis of the present data, it appears that the best temperature for conducting the $\mathrm{Br} \mathrm{F}_{5}$ fluorination step is within the range from 250 to $300^{\circ} \mathrm{C}$. However, to explore this area more completely, experiment Purse -15 has been performed with a $\mathrm{BrF}_{5}$ fluorination step at $350^{\circ} \mathrm{C}$. The results of analyses of the final bed from this experiment are not available. 
A series of two experiments were performed to determine if the presence of $\mathrm{BrF}_{3}$ in fluorine would suppress fluorination of plutonium. The experiments were carried out in a horizontal tubular reactor using simulated fuel mixtures containing $10 \mathrm{~g}$ uranium as $\mathrm{U}_{3} \mathrm{O}_{8}, 0.3$. g plutonium as $\mathrm{PuO}_{2}, 0: 2 \mathrm{~g}$ nonradioactive fission product oxides and $12 \mathrm{~g}$ of alumina. A gas stream containing $93 \mathrm{v} / 0$ fluorine $-7 \mathrm{v} / \mathrm{O}^{\circ} \mathrm{BrF}_{3}$ was passed over the fuel mixtures at $250^{\circ} \mathrm{C}$. for $6 \mathrm{hr}$ in the first test and at $350^{\circ} \mathrm{C}$ for $3 \mathrm{hr}$ in the second test. In the first experiment, about $40 \%$ of the plutonium was volatilized as $\mathrm{PuF}_{6}$; about $80 \%$ was volatilized in the second experiment. Apparently, the presence of $\mathrm{BrF}_{3}$ at this concentration level in fluorine does not suppress the fluorination of plutonium.

(ii) Neptunium Fluoride Chemistry. Laboratory-scale studies are being carried out to determine the behavior of neptunium when oxidized nuclear fuel is reacted with bromine pentafluoride. Previous experiments have shown that $\mathrm{NpF}_{6}$ reacts readily with bromine (the product of the reaction between $\mathrm{U}_{3} \mathrm{O}_{8}$ and $\mathrm{BrF} \mathrm{F}_{5}$ ) at $30^{\circ} \mathrm{C}$ to produce solid $\mathrm{NpF}_{4}$ and $\mathrm{Br} \mathrm{F}_{3}$ (see Progress Report for November 1966, ANL-7279, pp. 69-70). It was observed that the reaction proceeded by an initial period at a high rate followed by a period at a lower reaction rate. This observation suggested that a secondary reaction between $\mathrm{NpF}_{6}$ and $\mathrm{BrF}_{3}$ to form $\mathrm{Br} \mathrm{F}_{5}$, as mentioned in the literature, ${ }^{9}$ might be occurring. This behavior was evaluated in two experiments: in: the first the total pressure of a gaseous mixture of $\mathrm{BrF}_{3}$ and $\mathrm{NpF}_{6}$ was measured over a $2-\mathrm{hr}$ pexiod, and in the second the infrared absorption of a $\mathrm{BrF}_{3}-\mathrm{NpF}_{6}$ mixture was followed for $2 \mathrm{hr}$. In neither case was any evidence for the formation of $\mathrm{BrF}_{5}$ observed; no change in pressure occurred, and there was no absorption at $644 \mathrm{~cm}^{-1}$, where $\mathrm{Br} \mathrm{F}_{5}$ shows characteristic abșorption.

Since the previously reported reactions of $\mathrm{NpF}_{6}$ with bromine were performed with $\mathrm{NpF}_{6}$ partially in the solid state, it is suggested that the change in reaction rate observed might have been due to the formation of solid $\mathrm{NpF}_{4}$ at the interface between solid $\mathrm{NpF}_{6}$ and the liquid phase, which would establish a diffusion barrier towards further reaction.

(iii) Separation of Neptunium from Plutonium. Thermal decomposition of $\mathrm{PuF}_{6}$ to solid $\mathrm{PuF}_{4}$ is being considered as a technique for separating plutonium from mixtures containing $U F_{6}$ and other fluorides. Since neptunium may be present as: $\mathrm{NpF}_{6}$ in these mixtures, the behavior of $\mathrm{NpF}_{6}$ during thermal decomposition of $\mathrm{PuF}_{6}$ must be determined.

Two experiments : were performed in which gaseous mixtures of $\mathrm{NpF}_{6}$ and $\mathrm{PuF}_{6}$ were circulated through a vessel at $300^{\circ} \mathrm{C}$. Each experiment was interrupted at hourly intervals to measure the quantity of solids deposited and to obtain samples for analysis. It was observed that

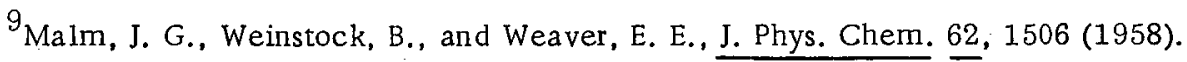


a small fraction of the neptunium $(\sim 0.2 \%)$ codeposited with the plutonium. The concentration of the neptunium in the deposited solids was constant throughout the entire deposition experiment. The fraction of the total neptunium in the gas mixture that codeposited with the plutonium was found to be dependent on the total quantity of plutonium deposited. The results suggest that selective thermal decomposition may be a feasible method for separating $\mathrm{NpF}_{6}$ from $\mathrm{PuF}_{6}$.

\section{b. Recovery of Uranium and Plutonium from Low-enrichment} Fuels: Engineering Work. Engineering development work is primarily directed toward the demonstration of various process steps in the fluoride volatility processing of oxide fuel using bromine pentafluoride as the fluorinating agent. The processing steps are shown in Fig. 10. In the process, Zircaloy-clad fuel is immersed in a fluid bed of refractory alumina and then contacted with hydrogen chloride at $350^{\circ} \mathrm{C}$ to remove the cladding as a volatile chloride. Since the direct reaction of sintered, massive oxide fuel with $\mathrm{BrF}_{5}$ does not proceed readily, the oxide fuel is pulverized to powder by reaction with oxygen prior to fluorination. Recovery of uranium is effected by selective fluorination (Fluorination $I$ ) of uranium to $\mathrm{UF}_{6}$ using $12 \mathrm{v} / \mathrm{o} \mathrm{BrF}_{5}$ at $300^{\circ} \mathrm{C}$, while plutonium is converted to nonvolatile $\mathrm{PuF}_{4}$ and remains in the fluid bed. The $U F_{6}$ is collected in a condenser with excess $\mathrm{BrF}_{5}$ and with the reaction product bromine. These materials, togethe $x$ with those fission product fluorides that are volatile, are separated by fractional distillation, resulting in a completely decontaminated $\mathrm{UF}_{6}$ product. The bromine, with some $\mathrm{BrF} \mathrm{F}_{3}$, is refluorinated to $\mathrm{BrF}_{5}$ by reaction with fluorine, and the $\mathrm{BrF}_{5}$ is recycled.

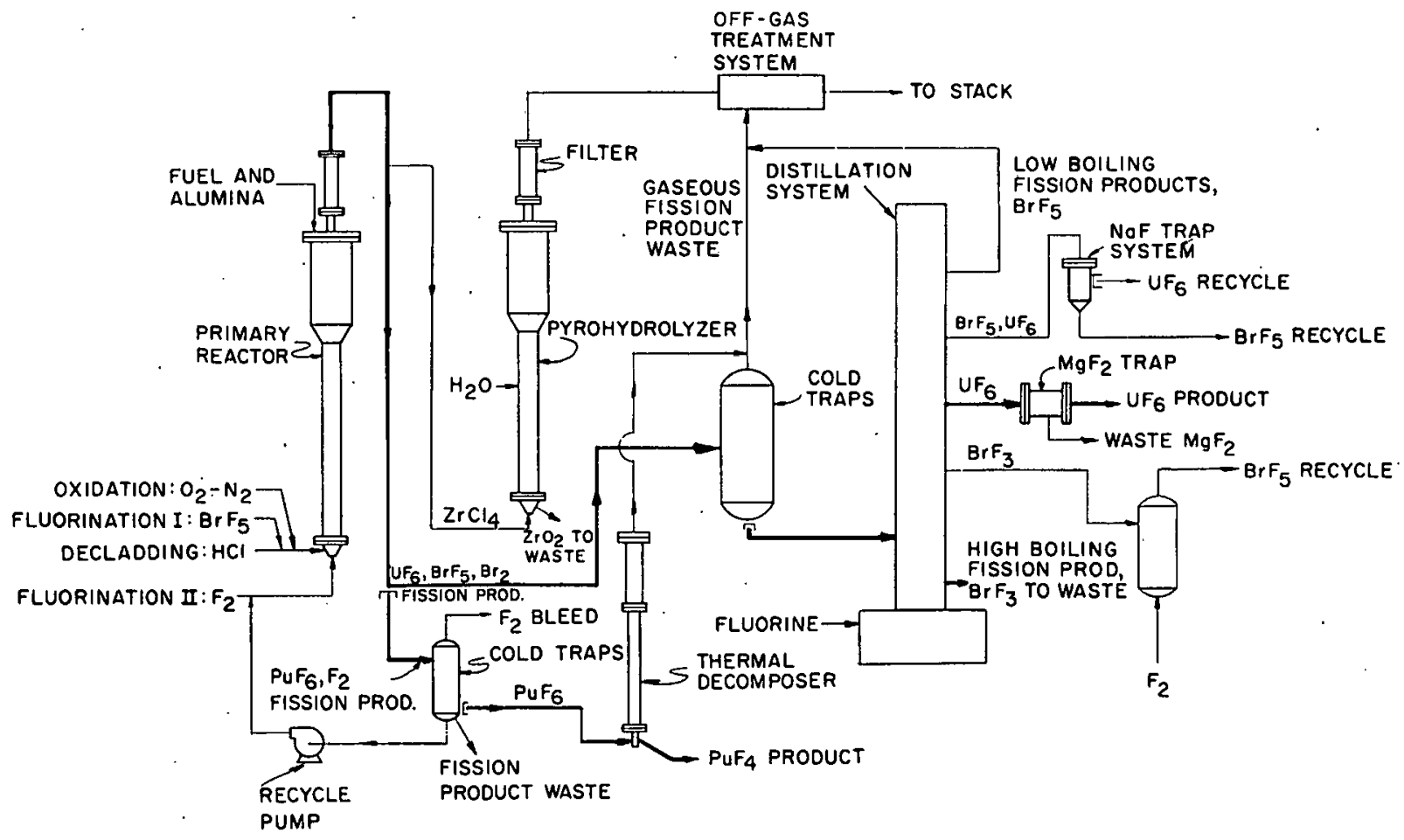

Fig. 10. Interhalogen Flowsheet for Reprocessing of $\mathrm{UO}_{2}$ Fuel Material Using Bromine Pentafluoride 
In the second fluorination step (Fluorination II), plutonium is recovered as $\mathrm{PuF}_{6}$ by fluorination of the $\mathrm{PuF}_{4}$ with fluorine gas at 300 to $550^{\circ} \mathrm{C}$.

Engineering-scale studies currently under way include:

(1) determining the effects of process variables on the fluorination of oxidized $\mathrm{UO}_{2}$ with $\mathrm{BrF}_{5}$ in a 3 -in.-dia fluid-bed reactor; (2) investigating the behavior of $\mathrm{PuF}_{6}$ in process equipment (engineering-scale alpha facility) during fluorination of $\mathrm{PuF}_{4}$ with fluorine; and (3) determining the distribution of fission products during the processing of highly irradiated $\mathrm{UO}_{2}$ fuel in a $1 \frac{1}{2}$-in.-dia fluid-bed reactor.

c. Engineering-scale Alpha Facility. The major objectives of experiments conducted in the engineering-scale alpha facility are to demonstrate handling of $\mathrm{PuF}_{6}$ on an engineering scale and to determine the feasibility of fluoride volatility flowsheets. The facility comprises two large alpha boxes: one contains process equipment, the other scrubbers and auxiliary equipment. The process equipment includes a fluid-bed fluorinator for fluorinating mixed oxide fuel to $\mathrm{UF}_{6}$ and $\mathrm{PuF}_{6}$, a converter reactor for converting $\mathrm{PuF}_{6}$ to $\mathrm{PuF}_{4}$ by thermal decomposition or for converting mixed $\mathrm{UF}_{6}$ and $\mathrm{PuF}_{6}$ to mixed oxide, and a system of condensers and chemical traps for collecting hexafluoride products.

Recent experiments in the facility have involved the fluorination of $\mathrm{PuF}_{4}$ powder in a fluidized bed of alumina to simulate the Fluorination II step of the interhalogen flowsheet (Fig. 10). In each of these experiments (Runs $\mathrm{Pu}-10,-11$, and -13) approximately $135 \mathrm{~g}$ of $\mathrm{PuF}_{4}$ in a bed of alumina $(6,700 \mathrm{~g})$ was fluorinated with fluorine at 200 to $550^{\circ} \mathrm{C}$. In $\mathrm{R}$ un $\mathrm{Pu}-10$, $41.5 \mathrm{~g} \mathrm{UF}_{4}$ and $41.8 \mathrm{~g} \mathrm{CsF}$ (simulating fission product cesium) were added to the bed; in Run Pu-11, $39.2 \mathrm{~g}$ of CsF were added. No cesium was added in Run Pu-13. The fluorination times were $14 \mathrm{hr}$ in Run $\mathrm{Pu}-10,52 \mathrm{hr}$ in Run Pu-11, and $29 \mathrm{hr}$ in Run Pu-13. Analyses of bed samples taken periodically throughout the runs indicated that the rate of plutonium removal by fluorination was less in runs in which CsF was present, Runs Pu-10 and $\mathrm{Pu}-11$, compared to runs in which no CsF was present, $\mathrm{Pu}-13$ and $\mathrm{Pu}-6$ (see Progress Report for July 1966, ANL-7245, p. 47). The concentration of plutonium in the alumina beds after completion of the fluorination was higher $(-0.10 \mathrm{w} / \mathrm{o})$ in Runs $\mathrm{Pu}-10$ and $\mathrm{Pu}-11$ than in Run Pu-13 (0.004 w/o).

After Run Pu-13, while the alumina bed was still in the fluorinator, the entire system was fluorinated for $17.5 \mathrm{hr}$ to remove any plutonium from process vessels and lines. In this fluorination period, the bed was maintained at $550^{\circ} \mathrm{C}$, the sintered metal filters at $300^{\circ} \mathrm{C}$, and process lines at $300^{\circ} \mathrm{C}$. It was observed that the plutonium concentration in the bed did not decrease as a result of the additional exposure of the bed to fluorine at $550^{\circ} \mathrm{C}$. 
Run: Pu-14 was performed in the alpha facility with feed material generated in experiments that had been carried out previously in the laboratory-scale fluid-bed facility. This material represented the fluid bed after the uranium had been recovered by fluorination of oxidized $\mathrm{UO}_{2}-$ $\mathrm{PuO}_{2}$-fission: product pellets. with: $\mathrm{BrF}_{5}$. The charge to the fluorinator consisted of $6400 \mathrm{~g}$ of the mixture which contained $25.7 \mathrm{~g}$ of plutonium and $3 \mathrm{~g}$ of CsF: This material was contacted with $80 \mathrm{v} / 0$ fluorine for $9.7 \mathrm{hr}$ while the bed temperature was increased from 300 to $550^{\circ} \mathrm{C}$, and for $5.2 \mathrm{hr}$ at $550^{\circ} \mathrm{C}$. The final bed after fluorination contained approximately $0.01 \mathrm{w} / 0$ plutonium which represents the removal of about $98 \%$ of the plutonium. An additional clean-up fluorination step for $10 \mathrm{hr}$ at $550^{\circ} \mathrm{C}$ did not result in the fluorination of additional plutonium. This high plutonium removal suggests that the effect of CsF on plutonium retention may be less marked in the. presence of composite fission products.

Inspection of the fluid-bed reactor after $\mathrm{Run} P \mathrm{Pu}-\mathrm{ll}$ revealed that the two sintered metal filters in the disengaging zone of the fluorinator were severely corroded. The temperature of the filter zone during the major portion of the fluorination: is maintained at $125^{\circ} \mathrm{C}$. However, near the end of the fluorination step, while the bed temperature is $550^{\circ} \mathrm{C}$, the filter temperature. is raised to $300^{\circ} \mathrm{C}$ to assure fluorination of any plutoniumcontaining fines: in the vicinity of the filters. The filters used in these experiments are fabricated from sintered.Monel powder. It is believed that the corrosion of the filters resulted from exposure to fluorine at temperatures above $300^{\circ} \mathrm{C}$ (e.g., at $375^{\circ} \mathrm{C}$ for a brief period). Both filters showed evidence of a nickel-fluorine reaction, and both.filters were replaced after Run Pu-11. Filters composed of sintered nickel fibers have recently become commercially available. These filters are known to have good corrosion resistance--superior to sintered.Monel--under these fluorination conditions: Filters of this type have been ordered for future use. 


\section{ADVANCED SYSTEMS RESEARCH AND DEVELOPMENT}

\section{A. Argonne Advanced Research Reactor (AARR)}

\section{General}

The architect-engineer, Burns and Roe, Inc., has completed the final draft of the specifications for Construction Package No. 1, primary pumps, and primary heat exchangers. These specifications are being reviewed by the project staff and the AEC.

Meetings were held with containment-structure contractors and the architect to discuss the containment liner and erection process. Based upon the information derived from these meetings a construction sequence was evolved for the reactor containment building.

The architect has started work on the outside utilities and the revamp of the 549A substation. Authorization has been given for the start of detailed architectural and structural design of the laboratory and office building and of the reactor containment building.

A final draft of the report on the computer control study by Burns and Roe has been received and is presently being reviewed by the project instrument and control group.

\section{Studies of Materials Compatibility and Corrosion}

Progress and results of this work, conducted at ORNL, have been reported regularly. ${ }^{10}$ The experimental portion was completed in July 1966 and the final report issued in November $1966 .{ }^{11}$ The following is an abstract from this report.

The purpose of the studies was to investigate the potential of corrosion to be expected in the multimaterial primary loop. This circuit includes the beryllium reflector, the aluminum beam tubes, and the stainless steel fuel element cladding, ${ }^{12}$ all of which are exposed to the high-purity primary coolant. All tests were consequently conducted in deionized water with a specific resistivity of $10^{6} \mathrm{ohm}-\mathrm{cm}$ or greater.

The beryllium exposure was made in a pump loop with water flowing past the specimen at $44 \mathrm{fps}$. The effect of exposed aluminum upon the

\footnotetext{
${ }^{10}$ Reactor Development Progress Reports ANL-7082, 7090, 7105, 7115, 7122, 7132, 7152, 7176, 7193, 7204, 7219 , and 7245 .

${ }^{11}$ Griess, J. C., and English, J. L., Materials Compatibility and Corrosion Studies for the Argonne Advanced Research Reactor, ORNL-4034. (Nov 1966).

12 The AARR will utilize aluminum cores (HFIR) in lieu of the initially planned stainless steel fuel.
} 
corrosion of beryllium in the loop was also investigated. Although the corrosion of beryllium showed a marked effect on the ratio of material surface to water volume, neither crevices nor contact with stainless steel or aluminum produced adverse effects.;...

The direct effect upon beryllium corrosion of aluminum corroding in the same loop is not clear.

A few randomly distributed pits were present on most of the beryllium specimens, the deepest being 3.2 mils. Except for these few pits, the the attack was uniform. The ratio of beryllium surface to volume of water in the AARR will place the corrosion to be expected in the range between 1.1 and $2.8 \mathrm{mpy}$, either of which would be acceptable.

Aluminum corrosion under conditions expected to exist at the tips of the 6061-T6 aluminum beam tubes with different cooling-water temperature and different heat fluxes was studied. Two tests were performed (see. ANL7176 and ANL-7219). The first test, designed to simulate conditions with $135^{\circ} \mathrm{F}$ cooling water of a velocity of $10 \mathrm{fps}$, resulted in the formation of a 3-mil-thick corrosion product layer in 75 days. The temperature drop across the corrosion product layer was $150^{\circ} \mathrm{F}$. A thermal cycle caused part of the corrosion product to spall from the surface, but on continuation of the test the corrosion product reformed at about the original rate. The heat flux was $820,000 \mathrm{Btu} / \mathrm{hr}-\mathrm{ft}^{2}$ and the water-oxide interface temperature was $260^{\circ} \mathrm{F}$.

The second test, simulating a $120^{\circ} \mathrm{F}$ cooling water inlet temperature was conducted under similar conditions except that the heat flux could be reduced to $400,000 \mathrm{Btu} / \mathrm{hr}-\mathrm{ft}^{2}$ in order to maintain the required interface temperature of $200^{\circ} \mathrm{F}$. Under these conditions only about $0.65 \mathrm{mil}$ of corrosion product formed; during an 85-day exposure. These results indicate that if the surface temperature of the beam tube tips can be maintained at $200^{\circ} \mathrm{F}$ or less, the buildup rate of corrosion product will be low enough to prevent excessive temperatures in the beam-tube walls.

The effects of heat flux on the corrosion of stainless steel was tested with beryllium and aluminum exposed in the loop. The results indicate that Type 304 stainless steel will not develop appreciable deposits on the heattransfer surfaces when exposed under thermal conditions similar to and even higher than those anticipated in the AARR.

At the conclusion of each of the two tests, the heat-transfer surfaces of the specimens were covered with a thin tarnish-like deposit. Metallographical examination revealed the presence of a film averaging about $0.1 \mathrm{mil}$ in thickness. The development of this film was not observed in the temperature measurement across the interface, probably because of a high thermal conductivity of the film. 
Special galvanic and crevice corrosion tests were conducted in an isothermal loop. Those tests lasted for an uninterrupted $3655 \mathrm{hr}$. Different combinations of stainless steel, aluminum, and beryllium were bolted together and exposed to deionized water at $200^{\circ} \mathrm{F}$, and at high (44 fps) as well as very low ( $2 \mathrm{fpm}$ ) flow velocity.

Examination of the specimen at the completion of the test revealed nearly complete absence of any nonuniform attack either in the crevice or on the exposed part of the specimen. Some of the aluminum coupons showed a few isolated pits, the deepest of which was only 1.5 mils. One of the beryllium surfaces in contact with stainless steel showed a single pit, 0.8 mil deep. All other surfaces, whether exposed to high or low velocity, were free of localized attack.

No indication of a galvanic effect was found in any of the tests.

3: Steady-state Heat-transfer Program

In the AARR steady-state heat-transfer program, the effects of channel spacing, flow, temperature of inlet water, pressure and power upon pressure differential along the channel, void distribution, and critical heat flux are measured in electrically heated, rectangular test sections that simulate the flat- or involute-plate geometrical arrangement of the AARR core. The tests discussed here were run at approximately 655 psia.

With a 30-mil test section, it was found that the channel had distorted under pressure (see Progress Report for May 1966, ANL-7219, p. 59); the center spacing was about $50 \mathrm{mils}$, while the spacing at the corners remained about 30 mils. Tests were also run with a 50-mil test section. It is possible to calculate an equivalent channel spacing from the adiabatic pressure-drop data. The results are: for the 50-mil test section, the equivalent channel spacing is $51 \mathrm{mils}$; for the 30 -mil test section, $47 \mathrm{mils}$. These values, $51 \mathrm{mils}$ and $47 \mathrm{mils}$, were used in the analysis reported here.

In examining the test results, it was found that near burnout a considerable amount of steam evidently exists at the outlet, even though the temperature of the bulk liquid is slightly subcooled. This was checked for a burnout point at $100 \mathrm{~kW}$, assuming a true heat balance of $98 \%$. If the outlet thermocouple temperature $\left(486^{\circ} \mathrm{F}\right)$ is assumed to represent the bulkliquid temperature, and if the steam is assumed to exist at saturation temperature $\left(496^{\circ} \mathrm{F}\right)$, then the flow quality is calculated to be $5.70 \%$. If a slip of 1.5 be assumed, a steam volume fraction of $58.1 \%$ was estimated. The void fraction actually measured for this case by gamma attenuation was $60 \%$.

In an alternative approach, the exit flow steam quality that would exist if equilibrium conditions prevailed was calculated as $4.2 \%$. When this 
result was used with the method devised by Levy ${ }^{13}$ to calculate the true nonequilibrium exit flow quality, a quality of $6.2 \%$ was obtained. If it be as sumed again that a slip of 1.5 existed, a steam volume fraction of $60.4 \%$ was found. These calculations indicate good agreement with the experimental: data.

The single-channel burnout points were compared with the additive or superposition type of critical heat-flux correlation proposed by Gambill. ${ }^{\mathbf{1 4}}$ For the forced-convection contribution, the McAdams equation for the heattransfer coefficient with a constant of 0.023 was used. For the pool-boiling contribution, the Zuber equation with the theoretical coefficient of $\pi / 24$ was used. A value of 1.4 was used for the ratio maximum to average heat flux which occurs at the exit of the test section.

Table XVII shows a comparis on of the experimental points with the correlation. The correlation predicts the results with deviations ranging from 4 to $26 \%$. This is well within the $40 \%$ range claimed by Gambill.

TABLE XVII. Comparis on of Predicted and Experimental Critical Heat Flux q" (in Btu/hr-ft ${ }^{2}$ )

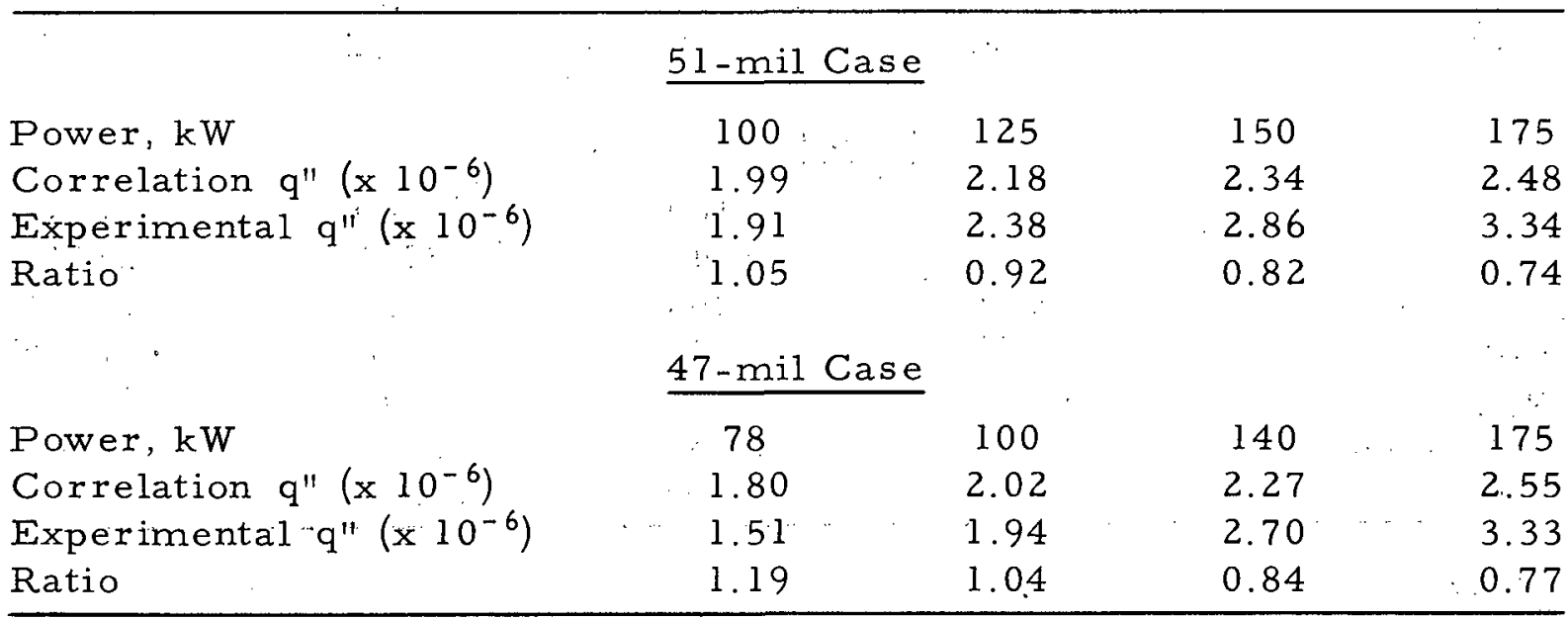

For multiple-channel systems, the minimum of the curve of the pressure drop versus flow is important in predicting the onset of flow instability. The design approach used for the HFIR core during normal operation is to maintain cooling conditions that prevent incipient nucleate boiling as predicted by the Bergles-Rohsenow correlation. ${ }^{15}$ The experimental pressure-drop minima were therefore compared with the flow for incipient nucleate boiling as given by this correlation. Table XVIII shows the results. The ratios of flows and pressure drops shown may be thought of as a form of safety factor, in that they indicate the ratio by which the flow or pressure

13 Levy, S., GEAP-5157 (April 1966).

14 Gambill, W. R., Chem. Eng. Progress Symposium Series 59, 71-87 (1963).

15 Bergles, A. E., and Rohsenow, W. M., Trans. ASME J. Heat Transfer, pp. 365-372 (Aug 1964). 
drop at incipient nucleate boiling is greater than that for the onset of flow instability. It will be noticed that the ratios of pressure drop range from 1.84 to 1.99 for the $5 \mathrm{l}-\mathrm{mil}$ channel, but is only 1.33 to 1.53 for the $47-\mathrm{mil}$. channel. This would seem to indicate that the pressure-drop safety factor is decreasing rapidly with decreasing channel spacing. However, the results for the 47-mil channel are less suitable for close analys is due to the greater scatter of the data, making it somewhat uncertain just where the minima occur.

TABLE XVIII. Comparis on of Incipient Nucleate Boiling Flow and Pressure Drop with the Flow and Pressure Drop Corresponding to the Minimum of the Curve of Pressure Drop versus Flow

\begin{tabular}{|c|c|c|c|c|}
\hline \multicolumn{5}{|c|}{ 51-mil Case } \\
\hline Power, kW & 100 & 125 & 150 & 175 \\
\hline $\mathrm{W}_{\mathrm{inb}}, \mathrm{lb} / \mathrm{min}$ & 27.0 & 35.2 & 43.1 & 50.4 \\
\hline $\mathrm{W}_{\mathrm{mpd}}, \mathrm{lb} / \mathrm{min}$ & 15.2 & 19.3 & 23.8 & 28.0 \\
\hline Ratio & 1.78 & 1.82 & 1.81 & 1.80 \\
\hline$\Delta \mathrm{p}_{\text {inb }}, \mathrm{psi}$ & 14.2 & 22.0 & 32.2 & 43.8 \\
\hline$\Delta \mathrm{p}_{\mathrm{mpd}}, \mathrm{psi}$ & 7.7 & 11.7 & 16.8 & 22.0 \\
\hline Ratio & 1.84 & 1.88 & 1.92 & 1.99 \\
\hline \multicolumn{5}{|c|}{ 47-mil Case } \\
\hline Power, kW & 78 & 100 & 140 & 175 \\
\hline$W_{\text {inb }}, 1 b / h r$ & 1161 & 1547 & 2216 & 2824 \\
\hline $\mathrm{W}_{\mathrm{mpd}}, \mathrm{lb} / \mathrm{hr}$ & 640 & 880 & 1230 & $1468^{a}$ \\
\hline Ratio & 1.81 & 1.76 & 1.80 & $1.92^{\mathrm{a}}$ \\
\hline$\Delta$ pinb $_{\text {in }}$ psi & 13.6 & 23.1 & 49.0 & 66.3 \\
\hline$\Delta p_{m p d}, p s i$ & 9.9 & 17.4 & 32.0 & $43.8^{\mathrm{a}}$ \\
\hline Ratio & 1.37 & 1.33 & 1.53 & $1.51^{\mathrm{a}}$ \\
\hline
\end{tabular}

Subscripts

inb $=$ incipient nucleate boiling

mpd $=$ minimum of pressure drop versus flow curve.

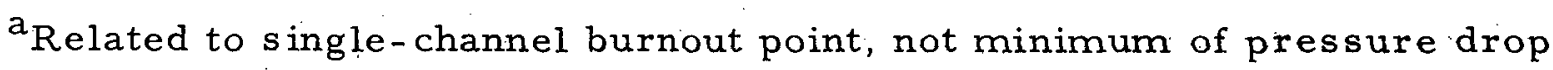
curve.

Another method of examining the flow instability is to consider the ratio of the exit temperature rise above the inlet temperature to the saturation temperature rise above the inlet temperature for the minima of the pressure drop versus flow curves. Table XIX gives these results. The values for the $51-$ mil channel range from 0.93 to 0.97 and appear reasonable based on previous studies using the computer code STDY $-3 .{ }^{16}$ The values for the 47-mil channel are somewhat more uncertain because of the greater scatter of data.

16STDY.-3, A Program for the Thermal Analysis of a Pressurized Water Nuclear Reactor during Steadystate Operation, WAPD-TM-213 (June 1960). 
TABLE XIX. Tabulation of the Quantity $r$ Gorresponding to the Minimum of the Curve of Pressure Drop versus Flow $\left(\mathrm{r}=\frac{\text { Exit temperature minus inlet temperature }}{\text { Saturation temperature minus inlet temperature }}\right)$

\begin{tabular}{|c|c|c|c|c|}
\hline \multicolumn{5}{|c|}{ 51-mil Cáse } \\
\hline Power, $\mathrm{kW}$ & 100 & 125 & 150 & 175 \\
\hline $\mathbf{r}$ & 0.972 & 0.956 & 0.934 & 0.928 \\
\hline \multicolumn{5}{|c|}{ 47-mil Case } \\
\hline Power, $\mathrm{kW}$ & 78 & 100 & 140 & 175 \\
\hline$r$ & 1.00 & 0.97 & 0.97 & $1.00^{\mathrm{a}}$ \\
\hline
\end{tabular}

It should be noted that in Tables XVIII and XIX the values for $175 \mathrm{~kW}$ in the 47 -mil. channel do not relate the single-channel burnout point to the minimum of the pressure-drop curve, since burnout occurred before a minimum pressure drop was established.

A comparison has also been made between the experimental pressure drop versus flow curves for heated test sections and the results as calculated with the computer code STDY-3. Figures 11 through 14 show the comparisons

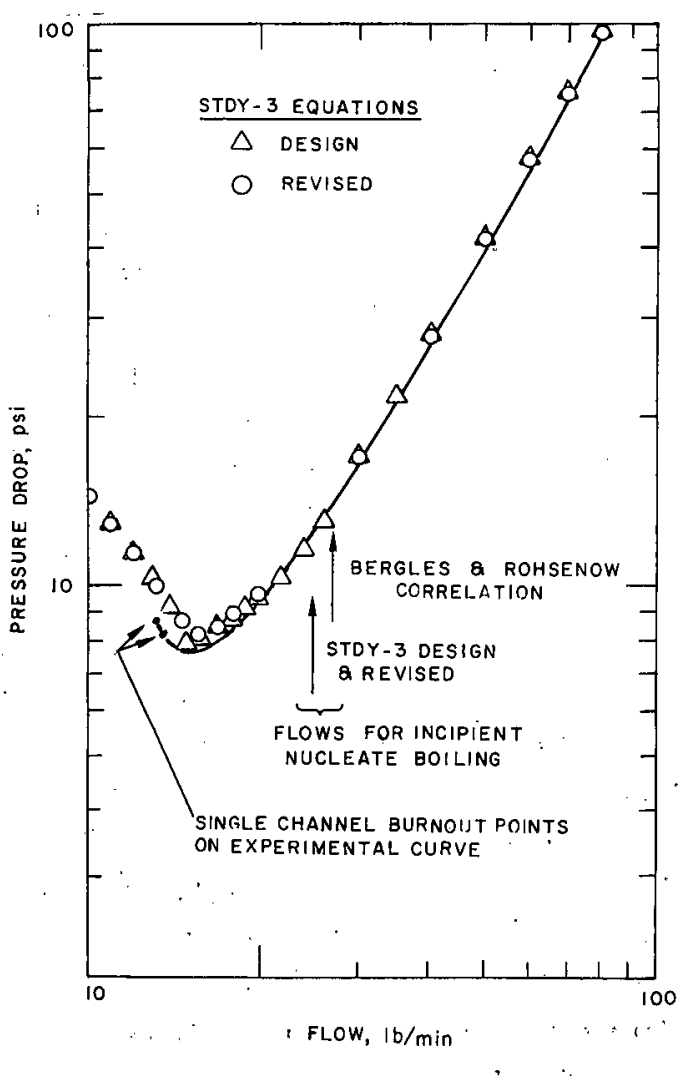

. Fig. 11. Comparison of Experimental and STDY -3 Curves of Pressure Drop vs. Flow for 50-mil Channel at $100 \mathrm{k} \hat{w}^{-}$

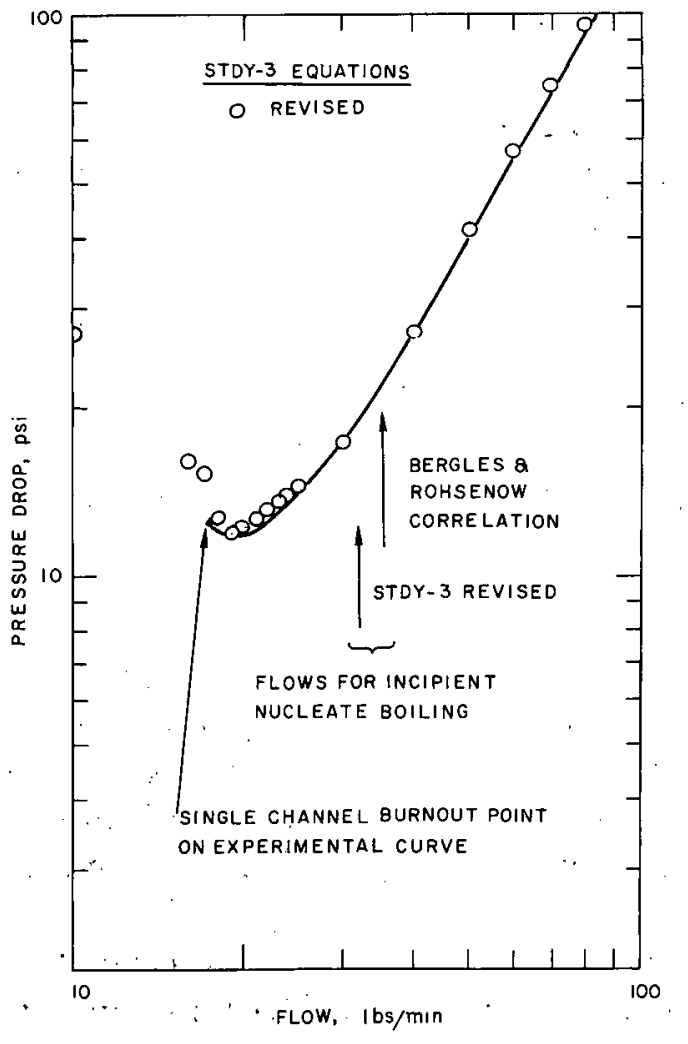

Fig. 12. Comparison of Experimental and STDY - 3 Curves of Pressure Drop vs. Flow for 50 -mil Channel at $125 \mathrm{~kW}$ 


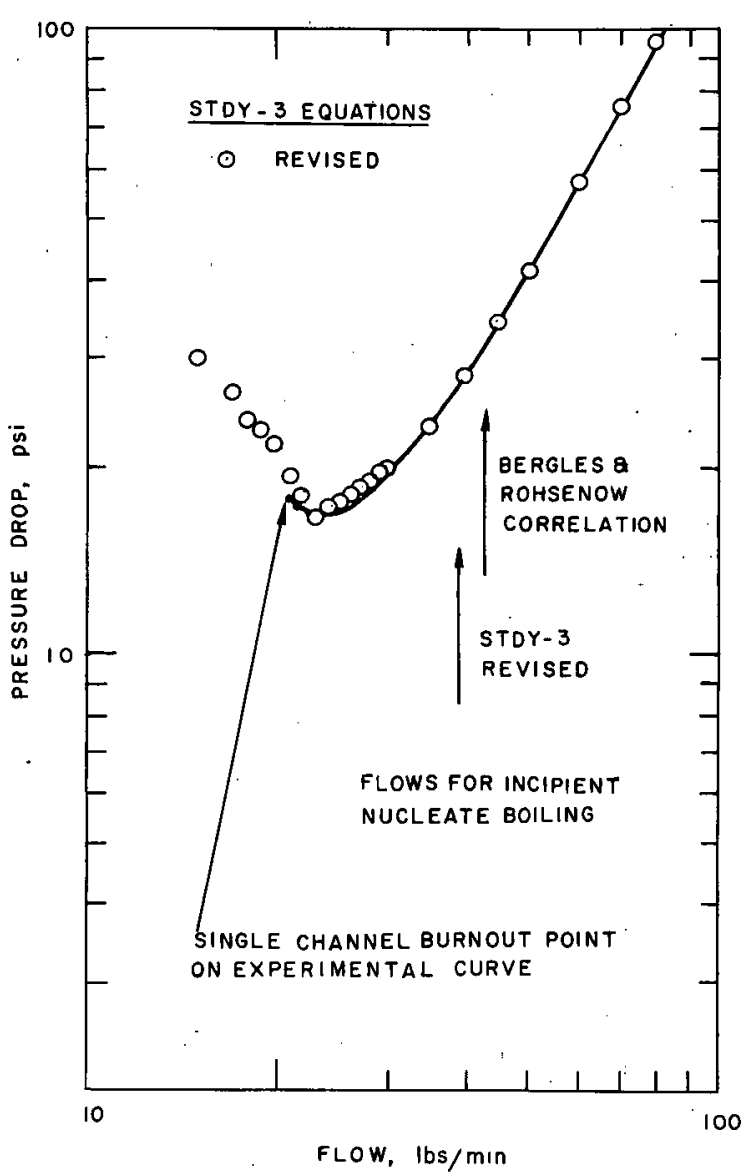

Fig. 13. Comparison of Experimental and STDY -3 Curves of Pressure Drop vs. Flow for 50-mil Channel at $150 \mathrm{~kW}$

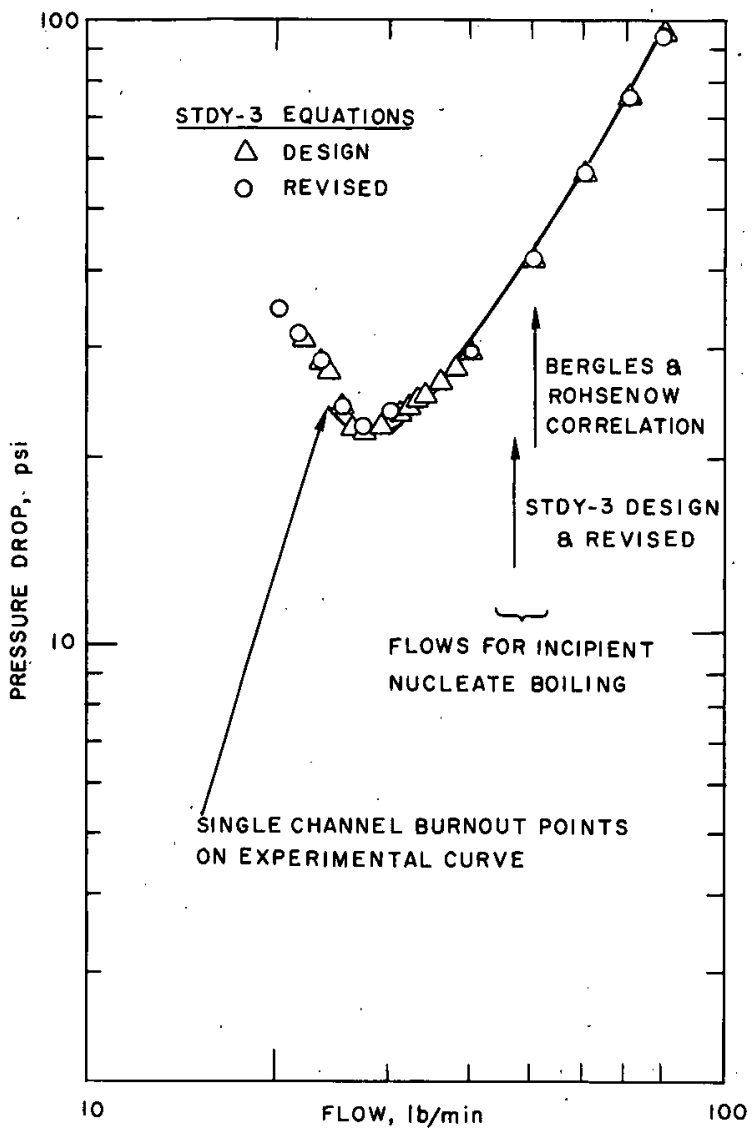

Fig. 14. Comparison of Experimental and STDY - 3 Curves of Pressure Drop vs. Flow for 50-mil Channel at $175 \mathrm{~kW}$

for the 50-mil channel at power levels of $100,125,150$, and $175 \mathrm{~kW}$. Also shown are the flows for incipient nucleate boiling as obtained from STDY-3 and as calculated from the Bergles and Rohs enow correlation (for these curves, velocity in $\mathrm{ft} / \mathrm{sec}=$ flow in $\mathrm{lb} / \mathrm{min}$ times 0.815$)$. The curves agree quite well.

In general, the behavior as predicted by STDY- 3 is as follows: At high flows the curve of pressure drop versus flow is a straight line on the log-log graph, corresponding to the conventional behavior of a single-phase fluid. As the flow is reduced, local boiling begins and the pressure-drop curve deviates from the straight line and becomes more nearly horizontal. Finally, at low flow, bulk boiling begins and the pressure drop jumps up sharply, causing a minimum in the curve, at the point of local boiling. As discussed above, the true behavior in the experimental situation appears to be more complicated; a nonequilibrium condition exists in which, at low flow, considerable steam exists at the channel exit even though the liquid is still slightly subcooled. However, the experimental and computed situations are sufficiently close so that the curves appear to agree fairly well. 
Figure 15 shows the results for the 30 -mil test section at $100 \mathrm{~kW}$. This test section distorted under pressure, expanding to approximately 50 mils in the central region, as shown in Fig. 16. The equivalent channel spacing for this case, as determined from the adiabatic pressure-drop curve, was 47 mils. Use of 47 mils in STDY-3 gives the lower pressuredrop curve shown in Fig. 15. It can be seen that, as the flow is reduced, the experimental curve begins to flatten out considerably earlier than does this lower, computed curve. This fact can probably be attributed to the beginning of local boiling in the corner regions of the channel, which would of course receive less flow than the central section, since the corners remained near 30 mils while the central section expanded to 50 mils. If a channel spacing of 30 mils is used in STDY-3, the upper curve in Fig. 15

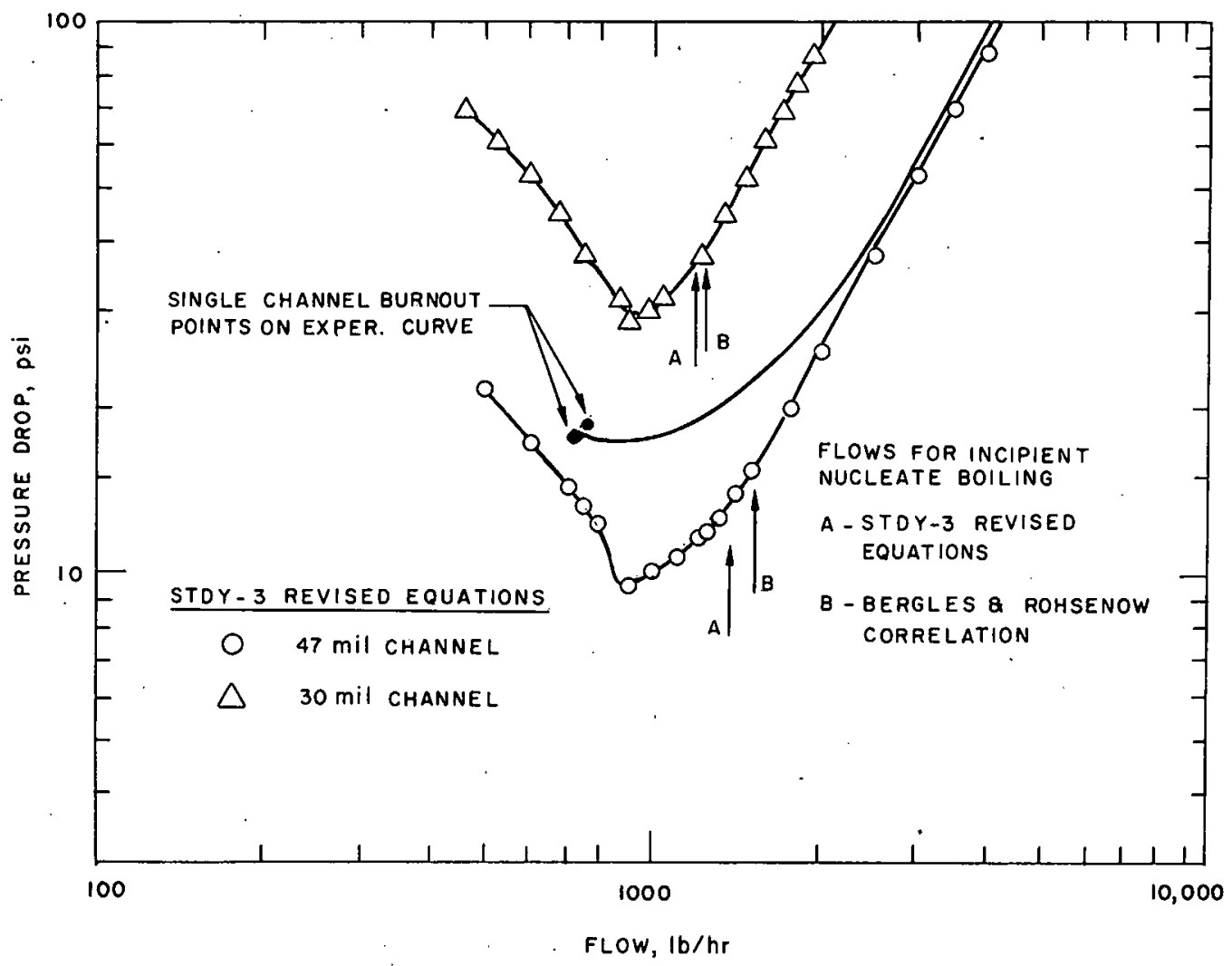

Fig. 15. Comparison of Experimental and Calculated Values of Pressure Drop vs. Flow for 30 -mil (nominal) Channel Operating at $100 \mathrm{~kW}$

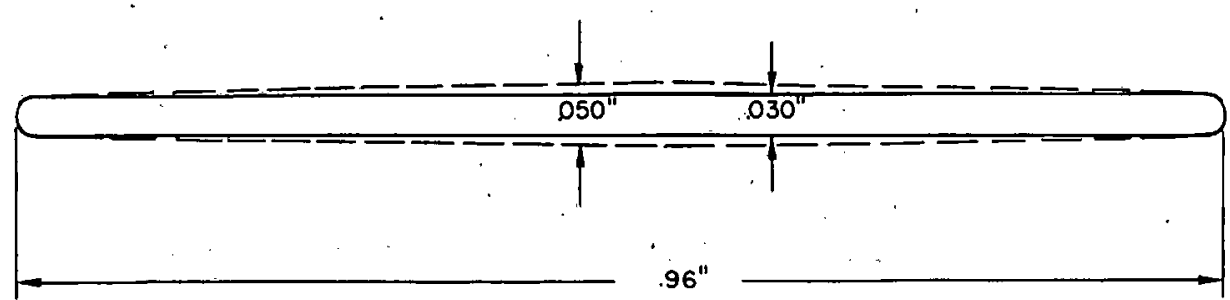

Fig. 16. Schematic of 30-mil Flow Channel Showing Expansion to Approximately 50 mils at Center Section 
is obtained. It can be seen that for the flows at which boiling is taking place, the experimental results might be thought of as being composed of an average or superposition of the upper and lower computed curves, since a portion of the channel area is behaving according to each of the two curves. The upper curve would at least be conservative in guiding reactor design for

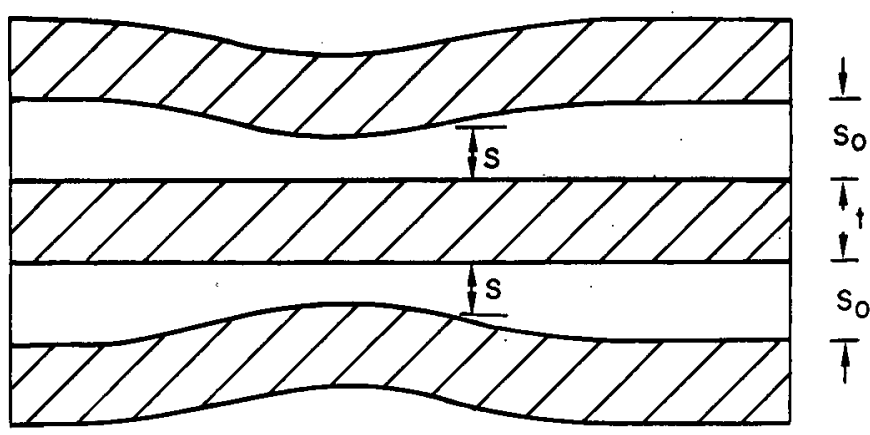

Fig. 17. Plan View of Hypothetical Configuration Showing Narrowing of Channel Spacing a hypothetically deformed channel spacing such as shown in Fig. 17. If a pressure drop corresponding to incipient nucleate boiling on the upper curve were applied across the reactor, it would produce sufficient flow to prevent failure via flow instability on the experimental curve. It should be noted, however, that in general the smaller the channel spacing, the closer will the flow for incipient nucleate boiling be to the flow for flow instability if the entire channel is at the small channel spacing. In other words, the safety factor associated with operating at incipient nucleate boiling is reduced if the channel spacing is very small.

\section{Physics Experiments and Analys is}

Analyses of the reactor physics characteristics of the AARR with HFIR-type fuel elements are continuing to supply important results of effects of perturbations, e.g., void coefficients of reactivity in the core and in the ITC. It has become increasingly apparent that more detail is required in the specification of region compositions, especially the removable portions of the beryllium reflector, to determine the absolute reactivity status. Such detail is not necessary, however, to determine the reactivity effects of the perturbations studied to date. Nevertheless, the specifications of all region dimensions and material compositions are being reviewed in fine detail.

Computations of the reactivity gain which would occur in the event of voidings of ITC water have consistently underestimated the measured reactivity gain. Detailed void-coefficient experiments have been reported previously (see Progress Reports for November 1965, ANL-7122, pp. 73-74; for December 1965, ANL-7132, pp. 55-56; for August 1966, ANL-7249, p. 69). These experiments involved ITC's of two different radial dimensions, with heavily loaded fuel zones (SS-U $\mathrm{U}^{235}$ fuel plates). It is believed that the loading of the fuel zone has only a second-order effect on the reactivity coefficient of voiding of ITC water, and analysis of these systems therefore has direct relevance to the ITC void coefficients in the AARR. Two-dimensional analyses of the $1215 / 1620$ loading, with the small ITC, have confirmed that the one-dimensional calculations underestimated the reactivity coefficients 
of ITC voidings principally because of the assumption that the effective bare-region height was unaffected by the voiding. The earlier onedimensional calculations implied a reactivity change of $1.1 \%$ for $50 \%$ void of the 18-in.-high active portion of the $100 \%-\mathrm{H}_{2} \mathrm{O}$ ITC. The two-dimensional calculations yielded a reactivity gain of $1.50 \%$ for a. $50 \%$ void, in excellent agreement with the measured value of $1.47 \%$ for a $49 \%$ void. The twodimensional problems were solved with the $2-D$ CANDID program on the CDC-3600 computer, in 6-group diffusion theory.

The $\mathrm{N}^{16}$ production rate in the operating reactor has been calculated. Approximately $1 \%$ of the fission-spectrum neutrons born with energy above I I $\mathrm{MeV}$ are captured by $\mathrm{O}^{16}$ to produce $\mathrm{N}^{16}$ by the $\mathrm{O}^{16}(\mathrm{n}, \mathrm{p}) \mathrm{N}^{16}$ reaction. The principal uncertainty in the analysis is the density of fission neutrons in this energy range. Rather than the Watt fitting to the fission spectrum; ${ }^{17}$ the more conservative formula $f(E)=a \sqrt{E} \exp (-E / T)$ has been used. ${ }^{18}$ At $11 \mathrm{MeV}$, the neutron density is roughly 3 times as large as the value implied by the Watt formula. This is a reflection of the uncertainty in the measurements of the fission spectrum above $10 \mathrm{MeV}$.

The production rate of $\mathrm{O}^{19}$, from $\mathrm{O}^{18}(\mathrm{n} ; \gamma) \mathrm{O}^{19}$, has been shown to be unimportant by comparis on with the $\mathrm{N}^{16}$ production. The $\mathrm{O}^{19}$ isotope has a half-life which is 4 times that of the $\mathrm{N}^{16}$; but the $\mathrm{N}^{16}$ activity dominates even after one minute of decay, which is the cycle time for the primary: coolant flow.

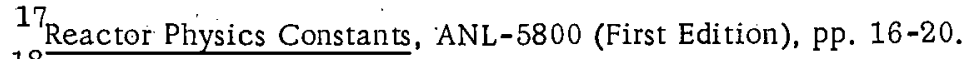

18 Reactor Physics Constants, ANL-5800 (Second Edition), July 1963, Table 1-10, p. 14. 


\section{A. Coolant Dynamics.}

\section{Coolant (Water) Expulsion Studies}

By means of a digital computer, all data for the runs in which complete expulsion occurred has been reduced. Analysis of this data has commenced.

Work on the data from the runs in which oscillatory flow resulted is still being programmed by the Applied Math Division.

\section{Superheat Experiments}

This experiment is designed to measure the degree of liquid superheat required to initiate nucleate boiling in sodium under various conditions simulating a reactor environment. Typical parameters will be systematically varied to determine their independent and combined effects upon the liquid superheat necessary to initiate nucleation. The parameters to be examined are: (a) pressure, (b) dissolved-gas content, (c) heat flux, (d) surface characteristics, and (e) the pressure-temperature history of the system.

Approximately 100 test runs have been completed. The superheat test runs to date include: (a) pressures ranging up to one atmosphere, (b) heat fluxes ranging to approximately $0.3 \times 10^{5} \mathrm{Btu} / \mathrm{hr}-\mathrm{ft}^{2}$, (c) liquid superheats required to initiate boiling, ranging up to approximately $200^{\circ} \mathrm{F}$, (d) steady-state superheats ranging from 20 to $40^{\circ} \mathrm{F}$, and (e) transient pressure pulses ranging up to 60 psia. Liquid sodium temperatures ranging up to approximately $1800^{\circ} \mathrm{F}$ have been obtained.

\section{Studies of Critical Flow}

Calculations of the progression of accidents in sodium-cooled reactors reveal that critical flow may exist in the core, leading to deterimental effects such as voidage of the coolant channel, shock phenomena, and pressure buildup.

The construction of equipment to study critical flow of different fluids is continuing. The sodium loop has been completed, and the first test section (ID $=1 / 16$ in. and $L / D=100$ ) has been installed in the loop. The loop has been filled with sodium. Final calibration of the instrumentation is being completed. 
A technique has been developed which definitely shows the existence of metastability in high-velocity, flashing, two-phase flow. The analysis is outlined briefly below.

Three assumptions are made:

a. one-dimensional analysis;

b. a different average velocity for each phase;

c. no viscous dissipation; therefore the acceleration of the fluid corresponds to the total pressure drop from the initial point of flashing.

At small qualities $(x<0.01)$, the above assumptions lead to an equation for the absolute minimum average vapor velocity which may exist under thermodynamic equilibrium conditions:

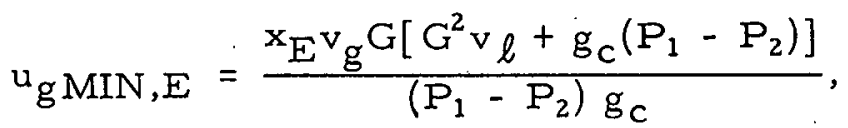

where

$P_{1}=P_{S A T}$ is the pressure at the initial point of flashing;

$P_{2}=$ pressure at the exit of the test section;

$G=$ mass flowrate;

$\mathbf{x}=$ quality;

$v_{g}=$ specific volume of the vapor;

$v_{l}=$ specific volume of the liquid;

$g_{c}=$ Newton's Constant;

$\mathrm{u}_{\mathrm{g}}=$ vapor velocity;

$\mathrm{h}_{\mathrm{g}}=$ enthalpy of the vapor;

$h_{f}=$ enthalpy of the liquid;

$\mathrm{s}_{\mathrm{g}}=$ entropy of the vapor;

$s_{f}=$ entropy of the liquid;

$\mathrm{J}=$ unit conver sion constant.

If viscous dissipation is included, larger values of the vapor velocity will result if thermodynamic equilibrium is maintained. 
However, the maximum possible vapor velocity that can be established may be calculated by assuming:

a. thermodynamic equilibrium consistent with the above analysis;

b. the vapor expands alone; saturated vapor expands isentropically from $P_{1}$ to $P_{2}$.

These assumptions lead to the following equation:

$$
u_{g \operatorname{MAX}, E}=\sqrt{2 g_{c} J \Delta H}
$$

where

$$
\begin{aligned}
\Delta H & =h_{g, 1}-\left[h_{f, 2}+x_{s}\left(h_{g, 2}-h_{f, 2}\right)\right] ; \\
x_{s} & =\frac{s_{g, 1}-s_{f, 2}}{s_{g, 2}-s_{f, 2}} .
\end{aligned}
$$

Three steam-water critical flow runs from this research have been examined with respect to the above analysis. The results shown in Table XX clearly indicate that when thermodynamic equilibrium is assumed, the twophase vapor velocity given by Eq. (1) is considerably higher than that calculated through Eq. (2) assuming an ideal vapor expansion. It can be argued that since the velocity given by Eq. (2) is the maximum velocity the vapor can acquire, some quantity in Eq. (1) must be in error. The equilibrium quality is the only calculated quantity in Eq. (I); hence, the actual quality must be considerably less than $\mathrm{X}_{\mathrm{E}}$. For example, in Run 2, the actual qual-

\begin{tabular}{|c|c|c|c|c|c|c|}
\hline Run & $\begin{array}{c}\mathrm{G} \\
\left(1 \mathrm{~b}_{\mathrm{m}} / \mathrm{sec}-\mathrm{ft}^{2}\right)\end{array}$ & $\begin{array}{c}P_{1} \\
\text { (psia) }\end{array}$ & $\begin{array}{c}P_{2} \\
(\text { psia) }\end{array}$ & $X_{E}$ & $\begin{array}{l}\mathrm{u}_{\mathrm{gMIN}, \mathrm{E}} \\
(\mathrm{ft} / \mathrm{sec})\end{array}$ & $\begin{array}{l}{ }^{u_{g M A X}}, E \\
(\mathrm{ft} / \mathrm{sec})\end{array}$ \\
\hline 1 & 3672 & 55.1 & 49.4 & 0.0046 & 1450 & 793 \\
\hline 2 & 3917 & 39.8 & 37.3 & 0.0032 & 3333 & 555 \\
\hline 3 & 3503 & 35.2 & 32.5 & 0.0039 & 3107 & 555 \\
\hline
\end{tabular}
ity can be no larger than one-sixth of the equilibrium quality.

TABLE XX. Analyses of Three Steam-Water Critical Flows

The above method definitely shows the existence of metastability, but only in a qualitative manner. 
4. Effect of Rapid Heating of Reactor Components

The mathematical model of the parallel-plate coolant-structure system (see Progress Report for October 1966, ANL-7267, p. 75) being used in the preliminary study of the influence of fluid-structure coupling on the pressure pulse and coolant expulsion has been simulated on the digital computer. The computer program was recently "debugged" and two runs have been made.

For the preliminary computation, the coolant was assumed to be water at a temperature of $212^{\circ} \mathrm{F}$ (no subcooling). The channel cross section is $2.5 \times 0.5$ in., with a heated length of 20 in. The channel walls are 2.5 in. wide and 20 mils thick. The input was assumed to be a rectangular power burst of $100-\mathrm{kW}$ peak power with a duration of $80 \mathrm{msec}$. The mathematical computation of such an assembly under such conditions gives a fundamental natural frequency of $697 \mathrm{cps}$. The results of one simulation are given in Fig. 18.

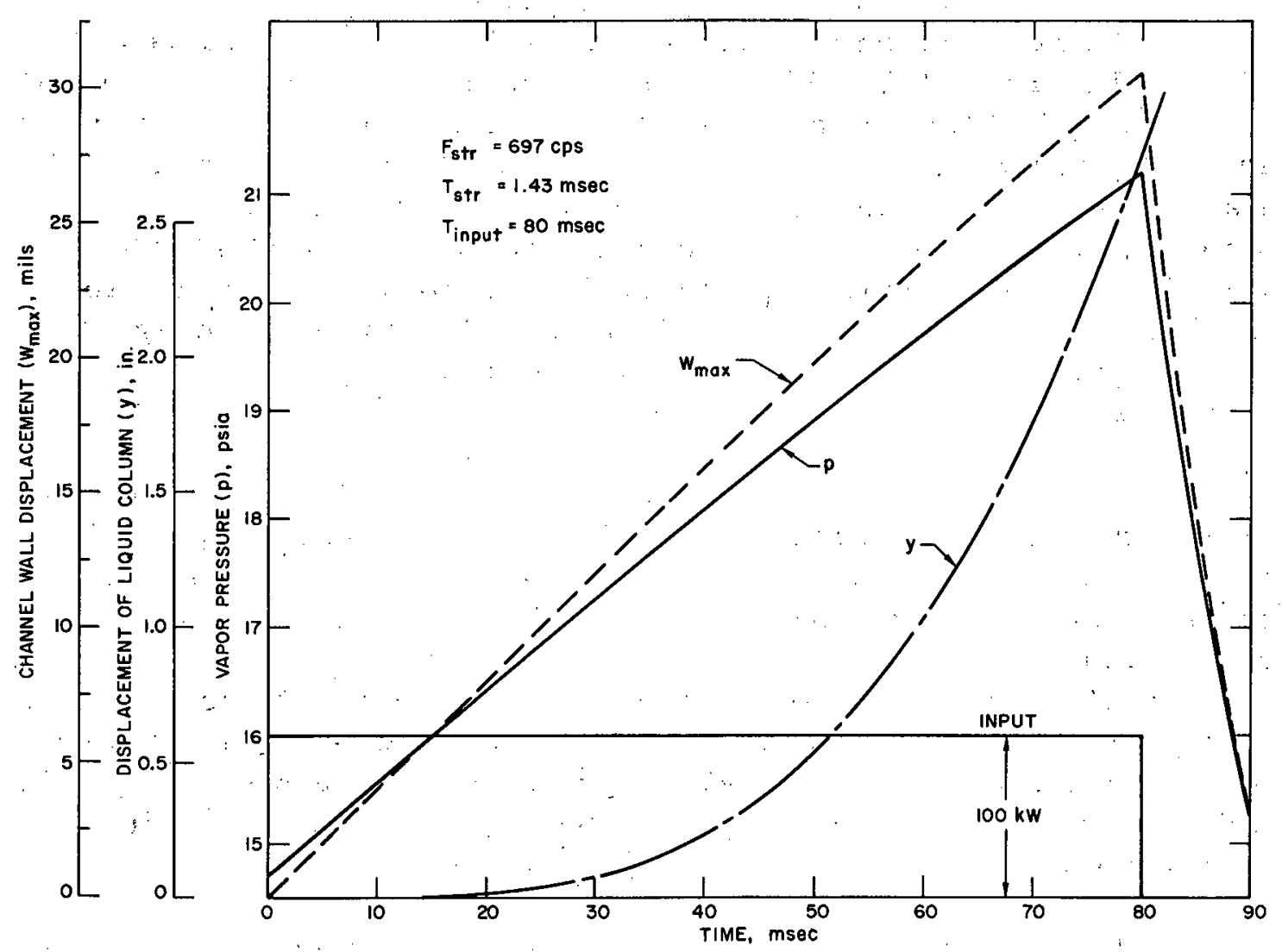

Fig. 18. Model Coolant-structure Response to Rectangular Pówer Burst

Because the period of vibration of the walls is $1.43 \mathrm{msec}$ ( $697 \mathrm{cps}$ ), which is much shorter than the input period, the response of the wall follows that of the pressure. At the peak pressure of 21.2 psia (1.44 atm), 
the maximum displacement of the channel walls is 30.5 mils, and the ex:pulsion height of the water is 2.75 in.

For the large channel cross-sectional area of this system, the. change in vapor volume, contributed by wall displacements of less than $30 \mathrm{mils}$, is negligible, and hence the structure would be expected to have little influence on the pressure transient and coolant expulsion.

Future runs will involve channel areas typical of those found in reactors and situations in which the structural period is of the order or greater than the input period.

\section{B. Fuel Meltdown Studies with TREAT}

\section{Data from Transient 1048}

TREAT reactor transients 1047 and 1048 were performed using a seven-pin cluster (one $9 \%$ enriched pin surrounded by six $7 \%$ enriched pins) of EBR-II Mark-I pins on the standard EBR-II pitch (see Progress Report for September 1966, ANL-7255, p. 83). : Transient 1047 was a low-energy, check run, whereas $\operatorname{Tr} 1048$ was a full-scale experiment producing gross sample failure and movements of the sodium coolant. Transient data from Tr 1048 are shown in Fig. 19. Inlet flow was measured with an electromagnetic flowmeter. The pressure transducer is located at the test-section inlet. The initial rate of coolant flow was about $3.25 \mathrm{~m} / \mathrm{sec}$ through the test section. Because the pump is of the alternating-current electromagnetic type, a 120-cps pressure signal is impressed on the inlet pressure transducer during normal operation.

The temperature of the outlet thermocouple rises smoothly as energy is released in the sample cluster, until approximately $600^{\circ} \mathrm{C}$ is reached, coinciding with a small pressure anomaly. A pressure spike of about 3.5 atm occurs at about 2.0 sec, correlated with an abrupt deceleration of coolant, which produces a maximum coolant expulsion $r$ ate of about

$5 \mathrm{~m} / \mathrm{sec}$. The time delay between the pressure spike and the beginning of the temperature response of the inlet thermocouple is about $0.068 \mathrm{sec}$. This may be compared with an estimated transit time of 0.066 sec for coolant (moving at the rates recorded by the inlet flowmeter) to travel from the center of the cluster to the inlet thermocouple.

If the sharp rises of both thermocouples between 2.0 and $2.1 \mathrm{sec}$ are assumed to result from a step change in temperature of coolant environment, a thermocouple response time of about $0.020 \mathrm{sec}$ can be deduced from the data. A time response of about $0.021 \mathrm{sec}$ has been calculated for these thermocouples. The higher (about 5 atm) secondary pressure spike does not have a direct correlation like the first. This second spike may be associated with upward expulsion of coolant followed by fall back on hot 

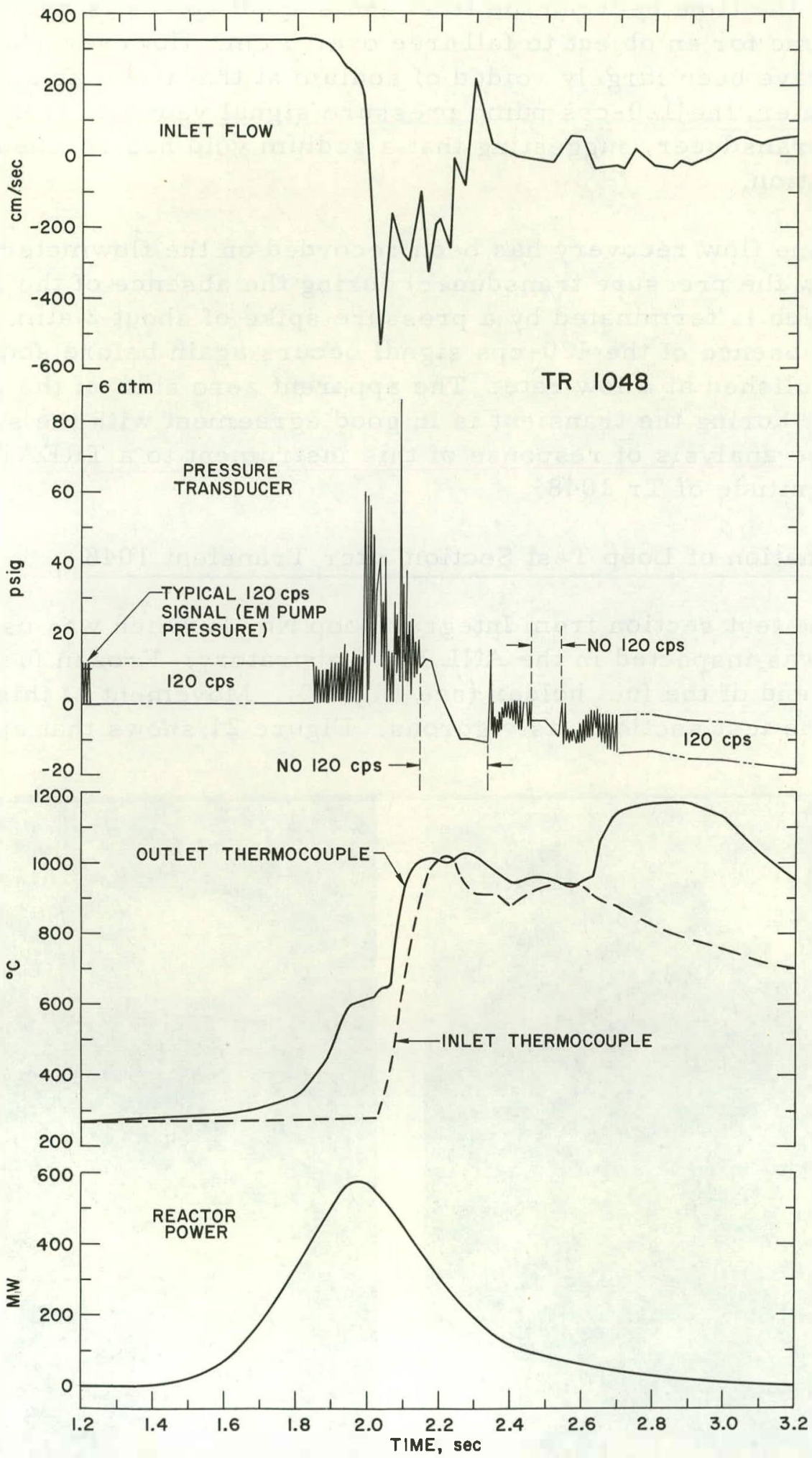

Fig. 19. Data Recorded for a Cluster of Seven Fuel Pins during Transient 1048 in the TREAT Facility 
fuel, since the time between the first and second spikes is approximately $0.1 \mathrm{sec}$, time for an object to fall free over $5 \mathrm{~cm}$. However, the test section may have been largely voided of sodium at that time, as approximately 0.05 sec later, the 120-cps pump pressure signal vanishes from the inlet pressure transducer, suggesting that a sodium void has reached the transducer location.

Some flow recovery has been recorded on the flowmeter (located $7 \mathrm{~cm}$ below the pressure transducer) during the absence of the $120-\mathrm{cps}$ signal, which is terminated by a pressure spike of about 2 atm. A second period of absence of the 120-cps signal occurs again before sodium flow is re-established at a low rate. The apparent zero shift of the pressure transducer during the transient is in good agreement with the semiquantitative analysis of response of this instrument to a TREAT transient of the magnitude of $\operatorname{Tr} 1048$.

\section{Examination of Loop Test Section after Transient 1048}

The test section from Integral Loop No. 1, which was used for Tr 1048, was inspected in the ANL Hot Laboratory. Frozen fuel was seen at the top end of the fuel holder (see Fig. 20). Movement of this fuel to the outlet of the test section was vigorous. Figure 21 shows that appreciable

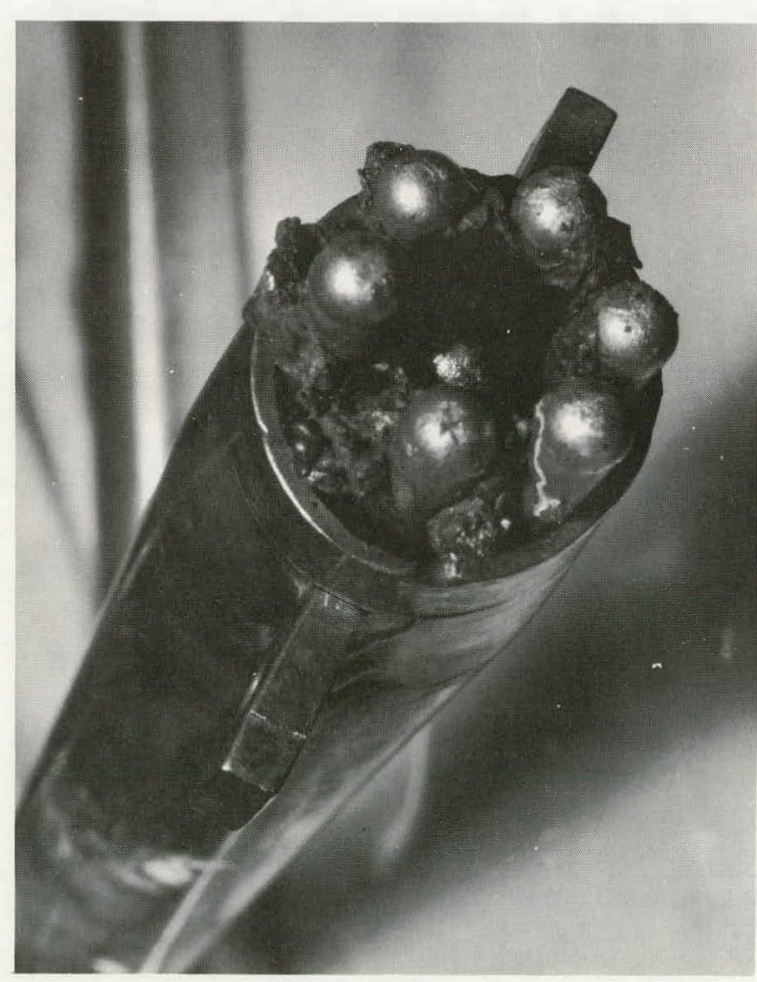

Fig. 20. View of the Top of the Fuel Holder Showing Deposits of Frozen Fuel Resulting from Transient 1048 Test of a Cluster of Seven Fuel Pins

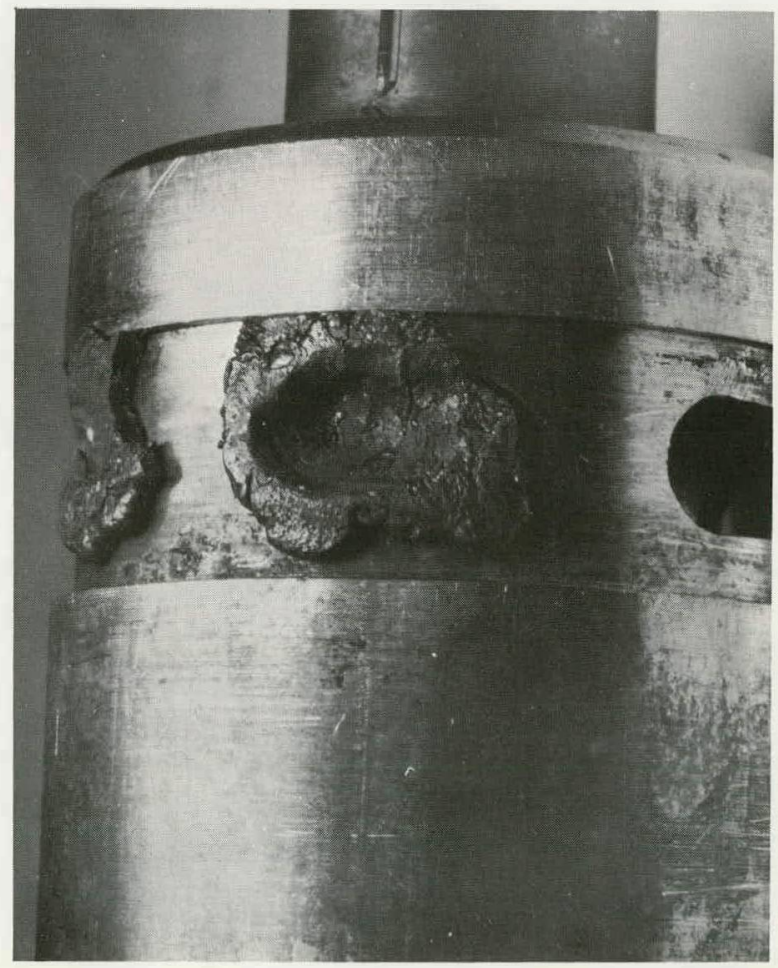

Fig. 21. View of Hold-down Fitting Which Was Located above the Test Section and Shows Deposits of Frozen Fuel Resulting from Transient 1048 Test of a Cluster of Seven Fuel Pins 
fuel was transported in the molten state to the openings of the hold-down fitting above the test section. The frozen fuel in the openings was about one $\mathrm{cm}$ above the top of the holder shown in Fig. 20. The sharp rise in outlet thermocouple temperature to about $1175^{\circ} \mathrm{C}$ at about $2.7 \mathrm{sec}$ in Fig. 19 may represent the time of movement of this fuel. Additional fuel was found frozen at the inlet to the test section. Resolution of the sequence and timing of axial fuel movements must await analysis of the fast-neutronhodoscope record of the experiment.

It was necessary to split the fuel holder longitudinally with a milling machine to inspect the fuel remains. Complete failure was found after the holder had been opened. Only the extreme top and bottom ends of the cladding tubes remained identifiable. A small quantity of fuel remained in some of the cladding at the bottom. Fuel deposits were more pronounced toward the bottom of the test section. Most of the visible fuel was found frozen onto the inner wall of the fuel-holder pipe. All signs of flow indicated that molten fuel movement after it struck the pipe was downward. Some evidence was found for porosity of the fuel frozen at the bottom of the test section. A sample has been taken for metallographic examination in the ANL Hot Laboratory.

\section{Development of Mark-II Integral Sodium Loop Pump}

A Mark-II integral sodium loop is under development for use in safety experiments to be performed in TREAT. The annular linear induction pump for the loop has been designed; shop fabrication has begun on the pump alternating current coils, pole piece laminations, and pump bodies.

The pumps are to be tested on a pump test facility (designed for general-purpose use) which is now ready for filling with sodium. The entire test loop is mounted on a balance so that mass flow from a supply tank to a dump tank can be measured. It can be run either in the oncethrough mode of operation or in the recirculating mode. A pressure transducer is mounted on both sides of the test-pump location so that simultaneous measurements can be made of flow and pump pressure. Loop flow can be adjusted by control valves. Additional instrumentation consists of thermocouples and a permanent magnet, direct-current electromagnetic flowmeter. Test flow meters can be installed in series with the loop flowmeter for calibration. The loop also has a small auxiliary pump, an alternating-current electromagnetic pump with a capacity of about $4 \mathrm{gpm}$ at about a half-atmosphere of pressure.

\section{Accident Analyses}

There has existed for sometime a growing need to improve ability to analyze accident behavior of fast reactors. The nature of the problem has been changing, and the capability of the modern computer to execute 
larger computations has grown rapidly. A major effort in this direction was recently established at ANL in terms of the ARC (Argonne Reactor Computing) program development (see Progress Report for September 1966 , ANL-7255, pp. 39-41). The quasistative excursion code QXl will be incorporated into the Accident Analysis package as an integral part of the ARC system.

1. Safety Analysis Computing System

a. Heat Transfer. The steady-state heat transfer routine (see Progress Report for November 1966, ANL-7279, pp. 46-47) is now essentially complete. It includes a two-level implicit scheme (or CrankNicolson Scheme) ${ }^{19}$ which is used to compute the radial temperature profile (at any axial increment) at the end of $(k+1)$ th time increment from the knowledge of the various quantities at the end of kth increment. There are two major aspects in which the present scheme differs from the standard C. N. Scheme:

1) The radial temperature profile is predicted for (or extrapolated to) the middle of the $(k+1)$ th time interval from the profiles at the end of $(\mathrm{k}-\mathrm{l})$ th and $\mathrm{kth}$ time intervals. Thermal properties are evaluated for this predicted profile for use in the computation of temperatures at the end of $(k+1)$ th time interval. (See Ref. 1.) It is found that this approach is adequate to take into account the nonlinearity of the heat conduction equations and that the method does not suffer from any numerical stability limitations.

2) Radial spatial increments are not kept uniform. This is done primarily to consider the unequal thermal expansions in the radial increments.

The implicit method suggested by Back in Ref. 2 is used to obtain equations relating the fuel surface temperature and the average clad temperature.

Gauss elimination procedure is used to solve the (tridiagonal) matrix equation resulting from the implicit scheme.

Thermal expansion is considered in an "open loop" sense, in that the change in the dimensions are computed directly from the change in temperatures in any time interval. Thermal expansions may or may not be constrained. If constrained, the module for the Elastic-Plastic Deformations is used to obtain the varying dimensions. The code is capable of handling fuel melting.

19 Back, L. H., Trans. ASME, J. Heat Transfer, p. 89 (Feb 1962). 
b. Linking of the Heat Transfer and the Two-phase Coolant Flow Modules. Linking of the Heat Transfer and the Two-phase Coolant Flow Modules is in progress. Linking is being done in an overlay structure in accordance with the specifications of the ARC system.

The two modules are coupled by the heat flux between the clad surface and the coolant. For each axial segment $j$, the average heat flux $\phi_{j}^{k+1 / 2}$ for the time interval $(k+1)$ is projected from the heat flux at the end of the intervals $(\mathrm{k}-\mathrm{l})$ and $\mathrm{k}$. By means of this projected heat flux the Twophase Flow module computes the coolant temperatures $\mathrm{T}_{\mathrm{C}_{\mathrm{j}}}^{\mathrm{k}+1}$ and communicates with the Heat Transfer Module, which in turn computes all the fuel and clad temperatures at the end of the $(k+1)$ th interval. Heat flux at the end of the $(k+1)$ st time interval is now computed from knowledge of these temperatures.

The common area in the overlay is expected to contain only the primary communication variables, namely, the projected heat flux $\phi_{j}^{k+1 / 2}$, the coolant temperatures $\mathrm{T}_{\mathrm{c}_{\mathrm{j}}}^{\mathrm{k}+\mathrm{l}}$, and the time interval, $\Delta_{\mathrm{t}}^{\mathrm{k}+\mathrm{l}}$.

\section{Quasistatic Excursion Code QXI}

Testing of the QXI (see Progress Report for October 1966, ANL-7267, pp. 52-53) is in progress. Figure 22 shows the space-time dependence of the fast group of a two-group thermal reactor test problem as plotted by the CDC-160A computer system. The material constants, dimensions, and ramp rate were the same as given ${ }^{20}$ for the delayed critical excursion in the 240-cm core, with two exceptions. All transverse bucklings were reduced by the factor 0.9994528 to make the system critical. Also, the thermal-group velocity was $2.2 \times 10^{5} \mathrm{~cm} / \mathrm{sec}$ instead of infinite, as was the case for the problem given in the reference. The $Q X 1$ fluxes at 0.8 sec were $+0.27 \%$ at the larger maximum and $+0.01 \%$ at the smaller maximum (as shown in Fig. 22) relative to a WIGLE ${ }^{21}$ run of the same problem. These same differences were present in the thermal-energy group.

Further testing and feedback routine coding are being done in conjunction with the design of the ARC version of the system.

\footnotetext{
${ }^{20}$ Yasinsky, J. B., and Henry, A. F., Some Numerical Experiments Concerning Space-time Reactor Kinetics Behavior, Nucl. Sci. Eng. 22, 171-181 (1965).

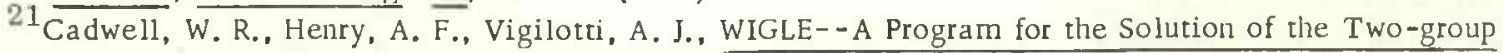
Space-time Diffusion Equations in Slab Geometry, WAPD-TM-416 (Jan 1964).
} 


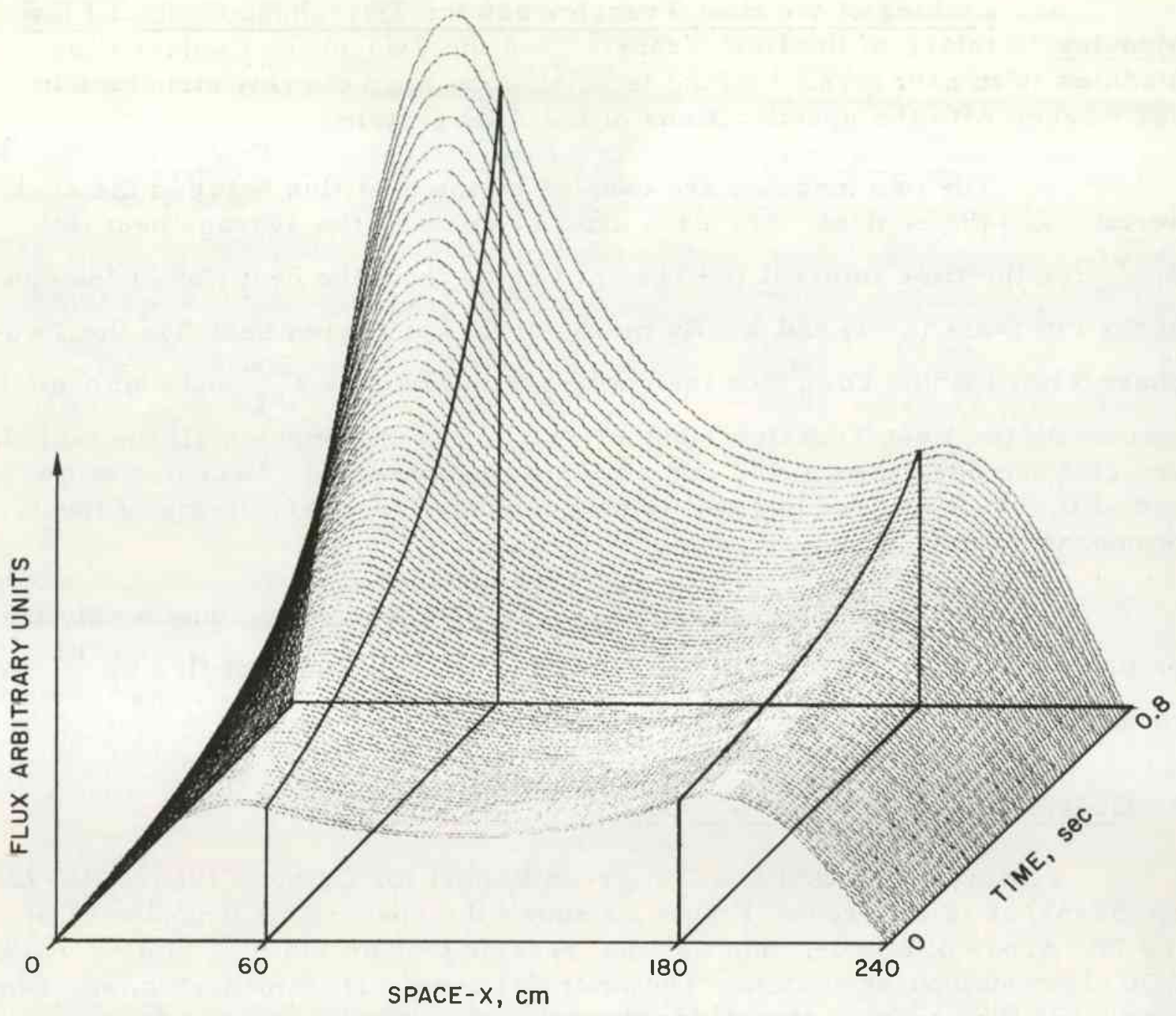

Fig. 22. Space-time Dependence of Fast Flux for the Yasinsky-Henry Delayed Critical Excursion Test Problem in the $240-\mathrm{cm}$ Core, as Calculated by QXI

\section{TREAT}

\section{Operations}

A sample of prototype Power Burst Facility fuel was subjected to ten transient ir radiations for the Phillips Peteroleum Company.

Two preirradiated $\mathrm{UO}_{2}$ samples were irradiated for ORNL to obtain data on release of fission products.

A stainless steel-clad $\mathrm{UO}_{2}$ pin (RP-48-5) that had been irradiated to $6 \mathrm{a} / \mathrm{o}$ burnup was subjected to two transient irradiations in a trans parent capsule. Photographic data from these transient tests will be compared with similar data obtained previously using unirradiated pins. 
E. Chemical and Associated Energy Problems (Thermal)

1. Metal-Water Reactions

a. Loss-of-coolant Simulation Experiments in TREAT on Zircaloy2-clad, $\mathrm{UO}_{2}$-core Fuel Clusters. Experiments were continued in TREAT to investigate the safety problems associated with the behavior of Zircaloy-2clad, $\mathrm{UO}_{2}$-core fuel rods during a loss-of-coolant incident (see Progress Report for February 1966, ANL-7176, p. 90). The purpose of the current tests is to obtain information on the chemical and physical changes which occur upon meltdown of the fuel cluster. Specific emphasis is placed on determining the extent of metal-water reaction, the temperatures and pressures produced, and the final distribution of particle size of the fragmented fuel. Three experiments have been performed, each on a progressively longer time scale. The first of these, CEN-217S, was reported previously (ANL-7176, p. 90).

The basic experimental technique consists of loading a "scaleup" autoclave with a fuel-rod cluster and water, and exposing the entire assembly to a neutron flux in TREAT. The construction of the autoclave, which is essentially an instrumented stainless steel pressure vessel, was previously described (see Progress Report for November 1964, ANL-6977, p. 83). However, in these simulated loss-of-coolant experiments, three fuel rods were used in each experiment and were located above the pool of water (instead of being submerged in it). Each fuel rod consisted of 10 sintered, fired $\mathrm{UO}_{2}$ pellets clad with Zircaloy-2. The fission heat generated in the $10 \%$ enriched $\mathrm{UO}_{2}$ during the TREAT transient caused meltdown of the fuel rods. To achieve a more realistic simulation of a loss-ofcoolant incident, the TREAT reactor power level, and hence the neutron flux, was held as constant as possible during the experiments. These irradiations are therefore called "flat-top" transients, in contrast to the power excursion type which were studied previously in this program (see, for example, Progress Report for September 1965, ANL-7105, p. 81).

The arrangement of the fuel cluster and the support structure is shown in Fig. 23. The lower part of Fig. 23 shows a "Calrod" heater (bent into a loop to fit inside the autoclave) which is actually submerged in the water when the whole assembly is inserted into the autoclave. In two of the experiments this electrical heater raised the water temperature from the ambient $30^{\circ} \mathrm{C}$ to a value of $100^{\circ} \mathrm{C}$ just before the TREAT transient was initiated. Thus, in these experiments, a 1 -atm steam environment was provided for the fuel rods, which are located immediately above the water level. A tungsten-rhenium thermocouple is spotwelded to the cladding in the central portion of one of the fuel rods. A second thermocouple with a junction about $3 / 4 \mathrm{in}$. above the bottom (see Fig. 23) records the bulk water temperature and indicates when the hot fragments from the fuel cluster above have fallen down into the water. 


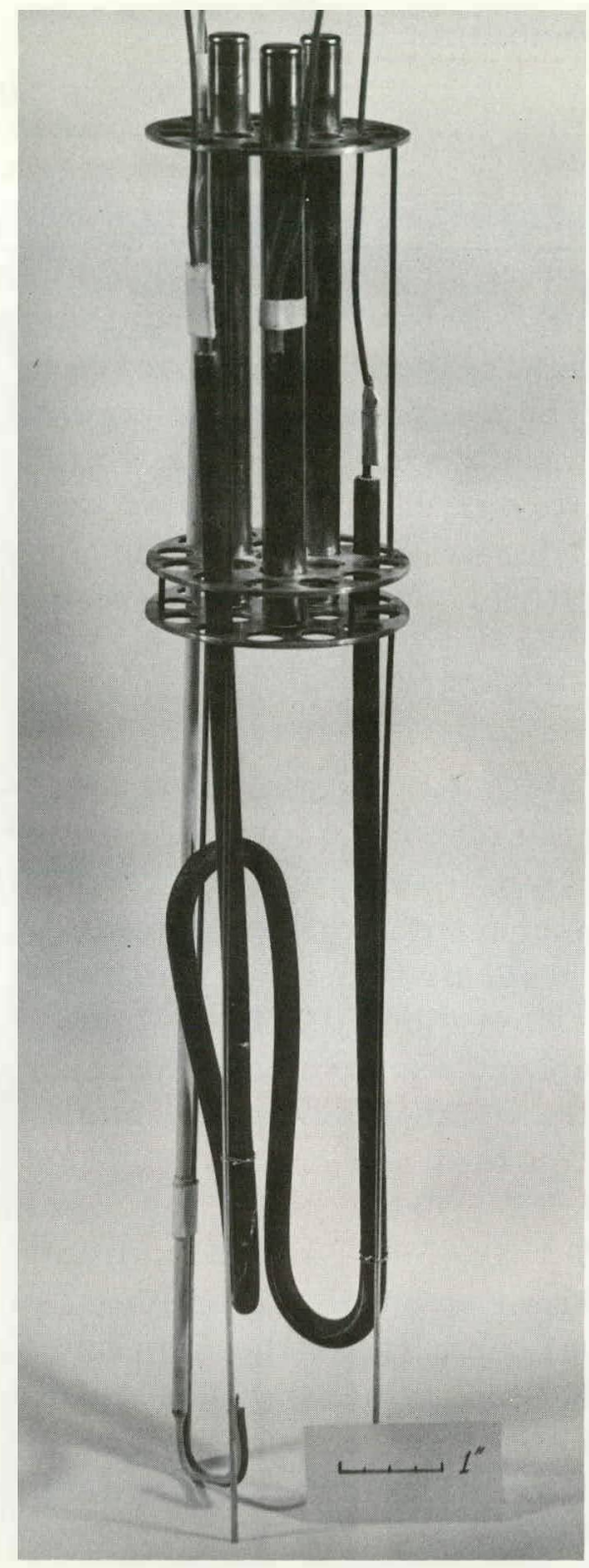

Fig. 23. Arrangement of Fuel Cluster for Loss-of-coolant Simulation Experiments in TREAT
Results from the three experiments which have been completed are summarized in Table XXI. The runs are arranged from the shortest time of fission heating ( $12 \mathrm{sec}$ ) to the longest ( $50 \mathrm{sec}$ ). (This is the time during which the reactor power is on.) However, in the third test the actual event continued for about $2 \mathrm{~min}$. During the first minute, the nuclear heat generation occurred, and during the second minute the cooling process took place while the pressure in the autoclave was still rising towards its maximum value. The time span of about $2 \mathrm{~min}$, even though quite short, approaches the times that are currently of interest in analyses of loss-of-coolant accidents. With decay heating, under reactor conditions, times from 10 to 15 min are generally of most interest.

One of the most significant features of the experiments is the appearance of the residues; portions of the cladding were present that retained the original cylindrical form of the cladding. These are particularly apparent in the residue from experiment CEN-217S (see ANL-7176, Fig. 28, p. 93), which had the fastest heating rate. Evidently, in this experiment, considerable quantities of molten $\mathrm{UO}_{2}$ emptied from the Zircaloy cladding before the cladding melted. This occurred to a lesser degree in experiment CEN-220S and to a still lesser degree in experiment CEN-223S, where progressively lower rates of fission heating allowed more time for heat transfer between the $\mathrm{UO}_{2}$ and the $\mathrm{Zircaloy}$.

The best indication of the time of the failure of the fuel rods is given by the time at which the temperature indicated by the cladding thermocouple peaked. Little information, however, is apparently provided by the temperature value itself at the peak. Values of 2430,1670 , and $1570^{\circ} \mathrm{C}$, respectively, were recorded for the three experiments. Table XXII gives the conditions of fuel at the time that the maximum temperature was recorded by the cladding thermocouple. It is evident from the table that sufficient fission energy had been generated at the probable time of failure to have at least partly melted the $\mathrm{UO}_{2}$. Another indication that the 
TABLE XXI. Summary of Results of Loss-of-coolant Experiments in TREAT with Zircaloy-2-clad, $\mathrm{UO}_{2}$-core Fuel Clusters ${ }^{\mathrm{a}}$

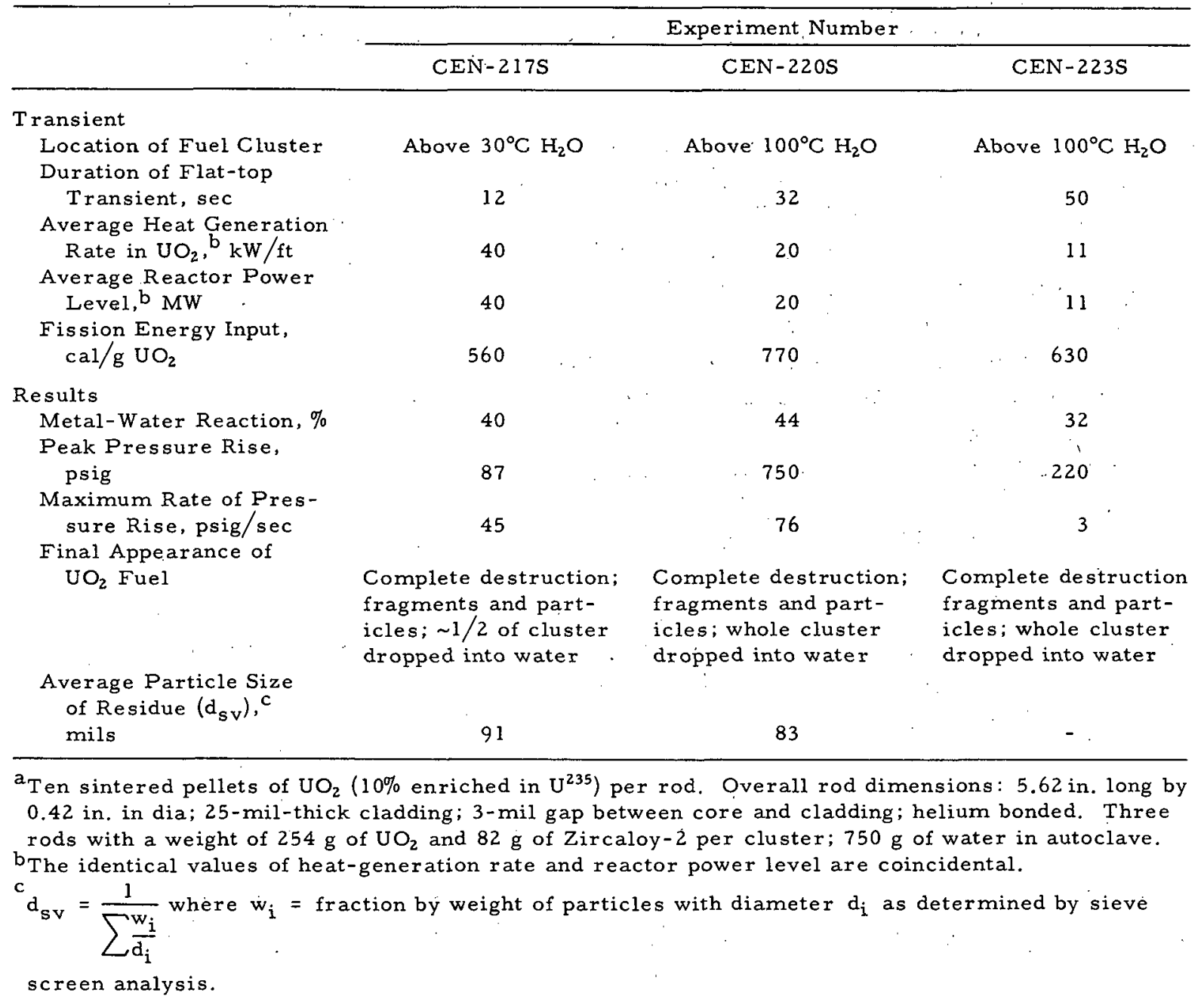

TABLE XXII. Condition of Fuel $\left(\mathrm{UO}_{2}\right)$ at the Time of Recording of the Maximum Cladding Temperature in Loss-of-coolant Experiments in TREAT

\begin{tabular}{|c|c|c|c|c|c|c|}
\hline $\begin{array}{l}\text { Experiment } \\
\text { Number }\end{array}$ & $\begin{array}{c}\text { Average } \\
\text { (Constant) } \\
\text { Heat } \\
\text { Generation } \\
\text { Rate } \\
(\mathrm{kW} / \mathrm{ft})\end{array}$ & $\begin{array}{c}\text { Peak } \\
\text { Recorded } \\
\text { Cladding } \\
\text { Temperature } \\
\left({ }^{\circ} \mathrm{C}\right)\end{array}$ & . & $\begin{array}{c}\text { Energy } \\
\text { Deposit } \\
\text { in Fuel } \\
\left(\mathrm{cal} / \mathrm{g} \mathrm{UO}_{2}\right)\end{array}$ & & $\begin{array}{l}\text { Adiabatic } \\
\text { Fuel Temp }\left({ }^{\circ} \mathrm{C}\right) \\
\text { and Physical } \\
\text { State of Fuel }\end{array}$ \\
\hline CEN-217S & 40 & 2430 & - & 360 & & $\begin{array}{l}3300 \\
\text { (fuel fully melted) }\end{array}$ \\
\hline$C E N-220 S$ & 20 & $1670^{c}$ & & 240 & · & $\begin{array}{c}2800 \\
\text { (fuel partly melted) }\end{array}$ \\
\hline$C E N-223 S$ & 11 & 1570 & & 285 & & $\begin{array}{c}2850 \\
\text { (fuel fully melted) }\end{array}$ \\
\hline
\end{tabular}

\footnotetext{
${ }^{a}$ A heat-generation rate of $1 \mathrm{~kW} / \mathrm{ft}$ is typical of values of greatest interest in loss-of-coolant accident analyses. Such low values.cannot presently be sustained in TREAT for a sufficient time to produce fuel failure.

$\mathrm{b}$ The apparent randomness of the indicated temperature may be associated with the formation of hot spots (and cold spots) which were noted in motion-picture studies.

${ }^{C}$ The cladding thermocouple may have broken prematurely, since the temperature trace was lost at this point.
} 
time of failure of the fuel corresponds to the time of recording of the maximum cladding temperature, is that this time coincides within about 1 sec in each experiment with the beginning of a significant pressure rise within the autoclave.

Considerable-information regarding the nature and timing of the collapse can be obtained from the oscillograph records for the three experiments. In CEN-217S there was a very high heating rate; much of the $\mathrm{UO}_{2}$ flowed from intact tubes of cladding; collapse into the water was probably completed in about $5 \mathrm{sec}$. The $5 \mathrm{-sec}$ value is the approximate time from the recording of the peak cladding temperature to the completions of the pressure rise and water temperature rise. It was only in CEN-217S that the stainless steel support structure did not completely fail. Evidently, the loss of the heat source, molten $\mathrm{UO}_{2}$, from above the support structure was rapid enough to preclude melting of the structure.

In CEN-220S there was a more moderate heating rate, and indications are that collapse required from 10 to $20 \mathrm{sec}$. The major indication of collapse was the erratic behavior of the water-temperature thermocouple about $10 \mathrm{sec}$ after the time of recording of the peak cladding temperature. Autoclave pressure reached a peak value after another $10 \mathrm{sec}$ had elapsed, suggesting that collapse had been completed.

\section{In CEN-223S, the heating rate was $11 \mathrm{~kW} / \mathrm{ft}$ for a time of}

$50 \mathrm{sec}$. Autoclave pressure, however, rose uniformly for about 130 sec. Indications of water temperature increase were noted during a major portion of this time. It is concluded from this that collapse of the fuel cluster was rather slow and continuous for much of the $130-\mathrm{sec}$ time interval.

A very significant observation, based upon the particle-size distribution of the residues, is the absence of large quantities of very fine particles. This is a particularly encouraging result, "since it suggests that molten $\mathrm{UO}_{2}$ (and molten $\mathrm{UO}_{2}-\mathrm{Zr}-\mathrm{ZrO}_{2}$ mixtures) do not exhibit a marked tendency for spontaneous subdivision on being quenched in water. It is also noteworthy that the pressure-time traces showed no "spike" pressure rises, which suggests that no steam explosions or very violent boiling occurred as the molten fuel material entered the water pool, at least for the small-scale experiments performed in this study.

The total extent of metal-water reaction for the three experiments varied from 30 to $44 \%$. A number of factors complicate any detailed numerical analysis of the metal-water reaction during the experiments. During the initial heating period, the pressure in CEN-217S was 20 psia helium and only about 0.5 psia of water vapor. In the other two experiments, there was about 15 psia of water vapor pressure in addition to 20 psia of helium. There was no forced-convection flow in any of the experiments; however, the nature of the assembly of fuel rods suggests that 
a brisk circulation by natural convection would be established and that there would be considerable steam available for reaction, at least in CEN-220S and CEN-223S. The likelihood of steam being available above the support plate suggests that considerable reaction occurred prior to fuel collapse. The fact that vigorous fission heating continued after much of the fuel had fallen into the water suggests that a sustained reaction (supported by the high rate of fission heating) continued after collapse of fuel into the water. Considering that the entire quantity of fuel had melted and collapsed into the water, a reaction of only 30 to $44 \%$ is encouraging from an accident-analysis point of view. This result again provides evidence that, upon being quenched in water, Zircaloy-clad fuel is not susceptible to a self-sustained reaction to completion, so long as the cladding is not dispersed in the form of very fine molten droplets.

An analysis of energy sources and distribution was performed for the TREAT loss-of-coolant experiments, with the results summarized in Table XXIII. From the analysis it was concluded that from 20 to $26 \%$ of the total energy release was of chemical origin. The remainder was energy generated by fission. The overall thermal efficiency was the fraction of the total energy that was effective in heating and boiling water to reach the quasiequilibrium state existing at the time of peak autoclave pressure. The remaining energy had been dissipated to the autoclave walls. The efficiency varied from 40 to $70 \%$.

TABLE XXIII. Energy Calculations for Simulated Loss-of-coolant Experiments in TREAT

\begin{tabular}{|c|c|c|c|}
\hline \multirow{2}{*}{ 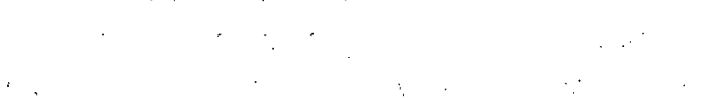 } & \multicolumn{3}{|c|}{ CEN-TREAT Transient Number } \\
\hline & $217 \mathrm{~S}$ & $220 \mathrm{~S}$ & \multirow[t]{2}{*}{2235} \\
\hline Nuclear Source: & & & \\
\hline Specific fission energy input, cal/g $\mathrm{UO}_{2}$ & 560 & 770 & 630 \\
\hline Total nuclear energy input, cal & 142,000 & 195,000 & 160,000 \\
\hline \multicolumn{4}{|l|}{ Chemical Source: } \\
\hline $\mathrm{H}_{2}$ evolved, STP, liters & 16.1 & $\quad 17.7$ & 12.9 \\
\hline Heat evolved from $\mathrm{Zr}-\mathrm{H}_{2} \mathrm{O}$ reaction, cal & 51,000 & 56,000 & 41,000 \\
\hline \multicolumn{4}{|l|}{ Total Energy Release: } \\
\hline Nuclear and chemical, cal & 193,000 & 251,000 & 201,000 \\
\hline Chemical contribution to total, $\%$ & 26 & 22 & 20 \\
\hline Specific energy input to water, cal $/ \mathrm{g} \mathrm{H}_{2} \mathrm{O}$ & 257 & 334 & 268 \\
\hline \multicolumn{4}{|l|}{ Calculated Final Conditions at "Equilibrium"a } \\
\hline Water temperature, ${ }^{\circ} \mathrm{C}$ & 117 & 257 & 184 \\
\hline $\mathrm{H}_{2} \mathrm{O}$ vapor pressure, psia & 26 & 648 & 159 \\
\hline $\mathrm{H}_{2}$ partial pressure, psia & 55 & 86 & 52 \\
\hline He partial pressure, psia & 26 & 35 & 30 \\
\hline Total "autoclave" pressure, psia & 107 & 769 & 241 \\
\hline \multicolumn{4}{|l|}{ Observed Final Condition at "Equilibrium" a } \\
\hline Pressure in autoclave, psia (max) & 107 & 770 & 240 \\
\hline \multicolumn{4}{|l|}{ Enthalpy Balance in System ${ }^{a}$} \\
\hline Total enthalpy increase (heat out) & 1 & & \\
\hline evaluated at final temperature, cal & 78,200 & 177,500 & 89,900 \\
\hline Heat lost into autoclave, $\%$ & 60 & 30 & 55 \\
\hline Corresponding thermal efficiency, $\%$ & 40 & 70 & 45 \\
\hline
\end{tabular}

${ }^{a}$ Evaluated at the time of peak autoclave pressure (12 sec in CEN-2175, $30 \mathrm{sec}$ in CEN-220S, and $130 \mathrm{sec}$ in CEN-2235). 
F. Engineering Safeguards Systems

\section{Containment}

A thorough study of the applicability of the energy-absorption concept to water-moderated reactors has shown that it is entirely feasible.

The first step was the construction of a flow-sequence diagram identifying the major events in a loss-of-coolant accident and their interrelationships. This was done in order that the energy-absorption concept could be viewed in its proper perspective. A study of the time duration of pressure pulses in a loss-of-coolant accident gave a range of hundreds of milliseconds to minutes, depending upon the extent to which the individual events, such as metal-water reactions, blowdown, and size of openings., influenced the overall sequence. Thus, for all practical purposes, the pressure loading on the energy-absorption container will be static. If a containment designed in accordance with the energy-absorption concept can withstand explosion of a given amount of TNT, it should be capable of withstanding an explosive accident in water-moderated reactors involving from three to ten times that energy release.

The usual assumption in a core excursion is that it is initiated at the center of the core. In reality, it is possible for the excursion to be initiated anywhere within the core volume. Thus, the eccentricity of the excursion with respect to the core center and its effect upon damage to the energy-absorption containment was considered. For present-day LMFBR, the ratio of core diameter to the concrete-wall radius is such that the difference in loading on the wall between center-initiated and noncenterinitiated excursions will be minor. This is due to the fact that the shock wave in the coolant decays quite rapidly so that the strength of the shock wave which hits the gas space before the concrete wall is practically independent of the eccentricity of the excursion. These statements do not hold true for future LMFBR designs in which the previously defined radii ratio approaches one. 


\section{PUBLICATIONS}

\section{Papers}

Comment on "Film Boiling Heat Transfer around a Sphere in Forced Convection" by K. Kobayasi

J. C. Hesson and L. C. Witte

J. Nucl. Sci. Technol. 3 (10), 448-449 (October 1966) Note

Plutonium Monitoring Techniques for ZPR-III

E. D. Graham, P. G. Stoddart, and F. W. Severn

Surface Contamination, Proc. Symp. Oak Ridge, June 8-12, 1964. Pergamon Press, Oxford, 1966, pp. 293-298

Dynamic Vibrations and Stresses in Elastic Cylinders and Spheres Gabriel Cinelli

J. Appl. Mech. 33E(4), 825-830 (December 1966)

Computational Procedures for Recent Analyses of Counterflow Heat

Exchangers

R. P. Stein

A.I.Ch.E. Journal 12(6), 1217-1219. (November 1966)

A Hybrid Computer Solution of the Co-Current Flow Heat Exchanger Sturm-Liouville Problem

L. T. Bryant, L. W. Amiot, and R. P. Stein

Am. Fed. Information Processing Societies 1966 Fall Joint

Computer Conf., Spartan Books, Wa shington, D.C., 1966, Vol. 29, pp. $759-769$

More on Dilution

Ira Charak

Nucl. Appl. 2(3), 268(1966) Letter

Response of a Boiling Water Channel to Power Modulation

C. C. St. Pierre, Michael Petrick, and S: G. Bankoff

Proc. Symp. on Two-Phase Flow, University of Exeter, June 21-22, 1965. Dept. Chemical Engineering, University of Exeter, Exeter, England, 1966, Vol. 1, pp. H101-H162

Three-Dimensional Stress Concentration around a Cylindrical Hole in a Semi-infinite Elastic Body

C. K. Youngdahl

J. Appl. Mech. 33E(4), 855-865 (December 1966)

Fast Neutron Scattering from $\mathrm{Be}, \mathrm{Na}$, and $\mathrm{Al}$

J. P. Chien

Nucl. Sci. Eng. 26, 500 (1966) 
ANL Reports

ANL-7157

DESIGN, PERFORMANCE, AND EVALUATION OF

SHIELDING WINDOW FOR FARET CONTAINMENT CELL T. W. Eckels and A. Smaardyk

ANL-7168

FAST REACTOR TEST FACILITY (FARET)

(Volume II) Volume II--Summary of Preliminary Safety Analysis

Edited by J. D. Geier

ANL-7195

DESIGN, CONSTRUCTION DETAILS, AND PREOPERA TIONAL TESTING OF AN ARGONNE FAST CRITICAL FACILITY

Leon R. Dates

ANL-7223 MACH 1, A ONE-DIMENSIONAL DIFFUSION-THEORY PACKAGE

D. A. Meneley, L. C. Kvitek, and D. M. O'Shea

ANL-7239

DYNAMIC BEHAVIOR OF CIRCULAR PLATES AND BEAMS WITH INTERNAL AND EXTERNAL DAMPING G. Cinelli

ANL- 7240

LABORATORY INVESTIGATIONS IN SUPPORT OF FLUID-BED FLUORIDE VOLATILITY PROCESSES. Part XIII. Condensed-phase Equilibria in the System Molybdenum Hexafluoride-Uranium Hexafluoride

L. E. Trevorrow, M. J. Steindler, D. V. Steidl, and J. T. Savage 